American University Washington College of Law

Digital Commons @ American University Washington College of

Law

Articles in Law Reviews \& Other Academic Journals

Scholarship \& Research

1992

Who Shall Rule and Govern? Local Legislative Delegations, Racial

Politics, and the Voting Rights Act

Binny Miller

Follow this and additional works at: https://digitalcommons.wcl.american.edu/facsch_lawrev

Part of the Election Law Commons, Law and Race Commons, and the State and Local Government Law Commons 


\title{
Who Shall Rule and Govern? Local Legislative Delegations, Racial Politics, and the Voting
}

\author{
Rights Act
}

\author{
Binny Miller ${ }^{\dagger}$
}

\section{CONTENTS}

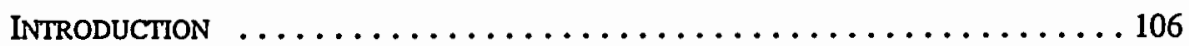

1. Legislative Delegations: A Functional Analysis $\ldots \ldots \ldots \ldots \ldots 113$

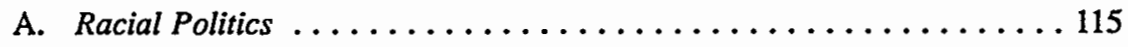

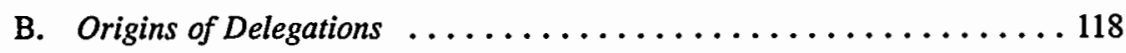

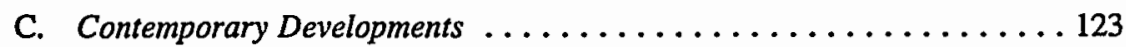

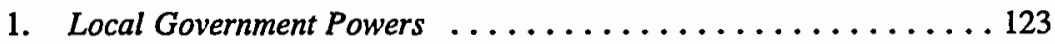

2. Procedures for Passing Local Legislation . . . . . . . . 127

3. The Richmond County, Georgia Delegation ............ 131

II. THEMES IN Voting RightS JURISPRUdENCE . . . . . . . . . 137

A. Election Procedures: Formal Barriers to Participation . . . . . . . 138

B. Vote Dilution: The Electoral Phase ................ 140

* Terry v. Adams, 345 U.S. 461, 469 (1953) (describing elective process as one "that determines who shall rule and govem in the county" $)$. In deploring the current state of politics, Professor Guinier has asserted that "[b]lacks may vote, but it is whites who will govern." Lani Guinier, Keeping the Faith: Black Voters in the Post-Reagan Era, 24 HARV. C.R.-C.L. L. REV. 393, 394 (1984). On a lighter note, Mario Cuomo has been quoted as saying "campaigning is poetry, while governing is prose." Andy Logan, Around City Hall, THE NEW YORKER, July 22, 1991, at 72.

$\dagger$ Associate Professor of Law, The American University, Washington College of Law. Although my work on this article has benefitted from conversations with many people, I am especially grateful to the voting rights activists of Augusta, Georgia, who aroused my interest in the machinations of local legislative delegations. Many former colleagues from the Voting Section of the Civil Rights Division of the United States Department of Justice added their insights; I am especially indebted to Nancy Sardeson, Dianne Thompson, Peyton McCrary, and Sheila Delaney. For thoughtful comments on earlier drafts of this article, I thank Robert Dinerstein, Ruth Eisenberg, Laughlin McDonald, Nancy Polikoff, Jamin Raskin, Robert Vaughn, and Burton Wechsler. I greatly appreciate the unswerving encouragement offered by Ruth Eisenberg, my law school colleagues, and other friends. Brian Benjet, Michael Lieberman, Justine CoffeyCannistra, and Alicia Benson contributed able and enthusiastic research assistance; Lauren Taylor provided helpful editorial assistance; and Marlene Spletzer and Anne White added valuable administrative support. I gratefully acknowledge the generous summer research grants provided by The American University, Washington College of Law.

This article is dedicated to the Honorable Barrington D. Parker, Jr., who taught me so much, and who shared with me his passion for equal justice and the values that illuminate legal doctrine. 
C. The Post-Election Phase $\ldots \ldots \ldots \ldots \ldots \ldots \ldots \ldots \ldots \ldots \ldots \ldots$

III. RIGHTS AND REMEDIES: DELEGATION DILUTION

AND THE VOTING RIGHTS ACT $\ldots \ldots \ldots \ldots \ldots \ldots \ldots \ldots \ldots \ldots$

A. Method of Determining Delegations' Composition:

Reapportionment, Annexation, and Delegation Gerrymanders ...... 152

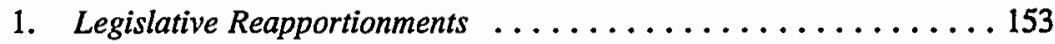

2. Fragmented and Submerged Counties: The Legacy

of the One-Person, One-Vote Principle . . . . . . . . . 154

3. Delegation Gerrymanders ................... 156

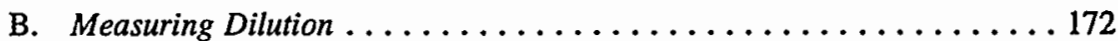

1. Traditional Measures ..................... 172

2. Applying Traditional Measures to Delegations . . . . . . . . . 175

3. Alternative Measures . . . . . . . . . . . . . . . . . . 179

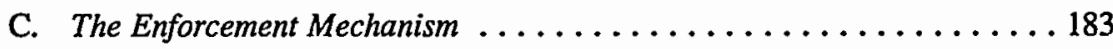

D. The Remedy ............................ 186

IV. Beyond DELEgations: Lessons for Legislative Functions $\ldots . . \ldots \ldots 189$

A. Delegation Rules and Procedures .................. 191

B. Who Has the Power? . . . . . . . . . . . . . . . . . . 196

C. After Presley ............................. 199

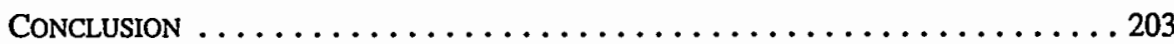

\section{INTRODUCTION}

Congress enacted the Voting Rights Act $^{1}$ as a radical measure to redistribute political power. ${ }^{2}$ This congressional intention should not be surprising, for at heart the struggle for voting rights has always been a battle for political power. ${ }^{3}$ Throughout this struggle, those who hold the reins of power have shared it only reluctantly, while consistently devising new, devious ways to remain in control. ${ }^{4}$ Indeed, a long line of voting rights cases attests to the

1. Voting Rights Act of 1965,42 U.S.C. $\& 1973$ (1988).

2. Pamela S. Karlan, Undoing the Right Thing: Single-Member Offices and the Voting Rights Act, 77 VA. L. REV. 1, 39 (1991) ("Voting Rights Act was intended to bring about a radical realignment of political control"). President Johnson heralded the passage of the Voting Rights Act as a "triumph for freedom as huge as any ever won on any battlefield." SENATE COMM. ON THE JUDICIARY, REPORT ON S. 1992, S. REP. No. 417, 97th Cong., $2 d$ Sess. 4 (1982), reprinted in 1982 U.S.C.C.A.N. 177, 181.

3. For a riveting account of the voting rights struggle, see JOHN HOPE FRANKLIN, FROM SLAVERY TO FREEDOM: A HISTORY OF NEGRO AMERICANS (1967); C. VANN WOODWARD, THE STRANGE CAREER OF JM CROW (2d rev. ed. 1966).

4. According to one commentator, "the focus of discrimination shifted [from preventing blacks from registering] to preventing blacks from using their eligibility to gain any significant political power." Armand 
intransigent, enduring nature of white resistance and illustrates the multiplicity of tactics politicians have employed to prevent blacks ${ }^{5}$ from gaining some measure of political authority. ${ }^{6}$

For most of this country's history, blacks were denied the right to cast a ballot. ${ }^{7}$ Once blacks gained the formal right to vote, however, the "white primary" and other disfranchising devices rendered it meaningless. ${ }^{8}$ After these blatant devices were invalidated by the Supreme Court, ${ }^{9}$ many cities and counties embraced new rules for elections intended to deny blacks any opportunity to prevail in election contests. ${ }^{10}$ Other municipalities sought to become white enclaves by fencing out black residents with artfully drawn jurisdictional boundaries. ${ }^{11}$ Finally, if black candidates did somehow succeed in winning elected office, whites sought as a last resort to render those offices politically impotent. $^{12}$

Derfner, Racial Discrimination and the Right to Vote, 26 VAND. L. REV. 523, 552-53 (1973). See also Perkins v. Matthews, 400 U.S. 379, 389 (1971) ("The history of white domination in the South has been one of adaptiveness, and the passage of the Voting Rights Act and the increased black registration that followed has resulted in new methods to maintain white control of the political process." (quoting director of United States Civil Rights Commission)).

5. In this article, I most often use the term "black," rather than the more general term "minority." The exclusive use of the term "minority" is unsatisfactory because it fails to convey the specific, historical discrimination against blacks and other people of color in the American political process. Although the Act extends rights to all racial minorities, as well as to non-English speakers or "language minorities," see David H. Hunter, The 1975 Voting Rights Act and Language Minorities, 25 CATH. U. L. REV. 250 (1976), I use the term "black" for several reasons. Local legislative delegations are most active in Southern states, where blacks are the largest racial minority group. Moreover, though "people of color" is more inclusive and might best capture the full range of protected groups, it is a cumbersome term to use in conjunction with "voter," and is a term found nowhere in the voting rights case law. However, by using the term "black," I do not mean to minimize the importance of the Act to members of other racial minority groups, or to suggest that the issues for all such groups are identical.

6. For an excellent history of voting discrimination, see generally Derfner, supra note 4.

7. J. Morgan Kousser, The Undermining of the First Reconstruction, in MNORITY VOTE DILUTION (Chandler Davidson ed., 1984).

8. See generally id. (describing literacy and property tests, poll taxes, and the white primary). Under the white primary system, only whites were permitted to vote in the Democratic primary. Id. at 33 \& n.24. Because victory in the primary was tantamount to election, the fact that blacks could vote in the general election was a hollow right. Terry v. Adams, 345 U.S. 461, 484 (1953) (Clark, J., concurring) (Democratic primary was "Iocus of effective political choice").

9. See infra notes $197-202$ and accompanying text.

10. Chandler Davidson \& George Korbel, At-Large Elections and Minority Group Representation, in MINORITY VOTE DILUTION, supra note 7, at 70-71 (describing changes in methods of election in southern cities in the 1940's and 1950's). It is no accident that a number of jurisdictions changed their election systems shortly after the white primary was abolished. Although these moves were cloaked in the garb of "good govemment," they often were thinly-veiled efforts to forestall the election of black candidates. Id. at 67-71. Ironically, the disfranchisement of black voters around the turn of the century through literacy tests, poll taxes, and other devices, was also heralded as a political "reform." See WoODWARD, supra note 3 , at 83 .

11. See Gomillion v. Lightfoot, 364 U.S. 339 (1960). In Gomillion, the city of Tuskegee, Alabama redrew its boundaries to exclude nearly every black resident from the city limits. The Court characterized this ploy as voting discrimination "cloaked in the garb of realignment of political subdivisions," $i d$. at 345 , accomplished "by fencing Negro citizens out of town so as to deprive them of their pre-existing municipal vote," id. at 341 .

12. See, e.g., Hardy v. Wallace, 603 F. Supp. 174 (N.D. Ala. 1985) (Alabama statute depriving blackcontrolled legislative delegation of certain powers and duties held subject to preclearance by Justice Department under Voting Rights Act). 
More than twenty-five years after the passage of the Voting Rights Act ("the Act"), and despite the fact that the political landscape has changed in important ways, ${ }^{13}$ significant barriers to full political participation for blacks still remain. These impediments have endured in the face of aggressive legislative and judicial action. The United States Congress has amended section 2 of the $\mathrm{Act}^{14}$ to emphasize that election systems that "result" in discrimination against racial minorities violate the Act, regardless of whether such devices were intended to discriminate. The amendment of section 2 has spawned successful challenges to discriminatory election practices in jurisdictions in every part of the United States, ${ }^{15}$ resulting in increased electoral success for minority-supported candidates. Recently, the Supreme Court has held that elections for candidates subject to popular election, including judges, must comply with the Act. ${ }^{16}$

Politics may no longer be a "whites only" club, ${ }^{17}$ but racial politicking still persists. As the more blatant barriers to full participation in the political process are removed, the challenge is to ensure that blacks are afforded the opportunity not only to vote, but also to govern. This goal has become more elusive because the Supreme Court, in Presley v. Etowah County Commission, ${ }^{18}$ promulgated a bright-line distinction between "voting" and "governance" for determining the scope of section 5 of the Act. ${ }^{19}$ Because Presley

13. Laughlin McDonald, The Quiet Revolution in Minority Voting Rights, 42 VAND. L. REV. 1249, 1250-52 (1989). One commentator has described this period as involving "wide-ranging federal regulation of the state political process." Daniel R. Ortiz, Federalism, Reapportionment, and Incumbency: Leading the Legislature to Police Itself, 4 J.L. \& POL. 653, 654 (1988).

14. Voting Rights Act Amendments of 1982, Pub. L. No. 97-205, § 2, 96 Stat. 131, 131-32 (codified at 42 U.S.C. \$ 1973 (1988)). For the text of amended section 2, see infra note 27.

15. See Katherine I. Butler \& Richard Murray, Minority Vote Dilution Suits and the Problem of Two Minority Groups: Can a "Rainbow Coalition" Claim the Protection of the Voting Rights Act, 21 PAC. L.J. 619,621 (1990) (plaintiffs victorious in "overwhelming majority" of cases decided under section 2). Prior to the amendment of section 2, most voting rights litigation was concentrated in the South; today, these lawsuits span the country. See, e.g., Buckanaga v. Sisseton Indep. Sch. Dist., 804 F.2d 469 (8th Cir. 1986) (lawsuit challenging at-large elections for South Dakota school district); Ketchum v. Byme, 740 F.2d 1398 (7th $\mathrm{Cir} .1984$ ) (challenge to racial gerrymander of Chicago city council wards), cert. denied, 471 U.S. 1135 (1985); Windy Boy v. County of Big Horn, 647 F. Supp. 1002 (D. Mont. 1986) (dilution challenge to atlarge elections); Campaign for a Progressive Bronx v. Black, 631 F. Supp. 975 (S.D.N.Y. 1986) (lawsuit by Hispanic voters challenging registration procedures).

16. Houston Lawyers' Ass'n v. Attomey Gen. of Tex., 111 S. Ct. 2376 (1991) (rejecting exception for "single-member offices" under section 2); Chisom v. Roemer, $111 \mathrm{~S}$. Ct. 2354 (1991) (judicial elections cognizable under section 2); Clark v. Roemer, 111 S. C. 2096 (1991) (judicial elections cognizable under section 5).

17. Prior to the reapportionment revolution, the typical southern legislature was "chiefly a body of Democratic, small-town or rural white men, a majority of whom represent a minority of the white population of the state." ROBERT G. DIXON, JR., DEMOCRATIC REPRESENTATION: REAPPORTIONMENT IN LAW AND Polmics 574 (1968) (quoting H.C. Nixon, The Southern Legislature and Legislation, 10 J. POL. 410, 412 (1948)).

18. 112 S. Ct. 820,832 (1992).

19. I share the widespread outrage that greeted the Presley opinion. In newspaper interviews, Professor Pamela Karlan's position was that "the ruling gives white elected officials a 'green light' to find a way to avoid sharing power with minority voters." Ruth Marcus, Court Relaxes Voting Act Restraints, WASH. POST, Jan. 28, 1992, at A6. Professor Lani Guinier stated that the opinion reflects "a very formal and shallow view of the right to vote." Linda Greenhouse, In Retreat, Supreme Court Limits Scope of '65 Voting Rights Act, 
has made it more difficult to challenge the allocation of power among different levels of government or between various government officials, safeguarding the right to vote at other stages of the political process has become even more important.

In this Article, I examine a group of powerful actors in the political process-local legislative delegations in state legislatures ${ }^{20}$ - that have largely escaped scrutiny under the Voting Rights Act. ${ }^{21}$ Local legislative delegations-sometimes referred to as legislative delegations, local delegations, or county delegations-are deliberative bodies composed of those state legislators elected from the legislative districts in the county. ${ }^{22} \mathrm{I}$ focus on delegations in Southern legislatures because the substantial decisionmaking powers conferred on Southern delegations make them especially influential. ${ }^{23}$ Because of their

N.Y. TMES, Jan. 28, 1992, at A1. See also Nat Hentoff, Clarence Thomas Joins the Wrecking Crew, WASH. POST, Feb. 15, 1992, at A27 (editorial describing case as "subversion of the Voting Rights Act"). The Court ignored earlier cases that conceived of the right to vote as part of an extended political process, see Terry v. Adams, 345 U.S. 461 , 469 (1953); United States v. Classic, 313 U.S. 299 (1941), as well as administrative and judicial precedent under section 5, see infra notes 249-57 and accompanying text. As the dissent in Presley noted at the outset, "this is a case in which a few pages of history are far more illuminating than volumes of logic and hours of speculation about hypothetical line-drawing problems." $112 \mathrm{~S}$. Ct. at 832-33 (Stevens, J., dissenting).

20. This Article explores an aspect of the political process that has received little scholarly attention. Although delegations undertake many legislative responsibilities, see infra notes 34-36, 97-124 and accompanying text, legislative delegations have received only passing reference in standard texts on state and local government. See, e.g., 1 CHESTER J. ANTIEAU, MUNICIPAL CORPORATION LAW (1991). With one exception, JAMES L. UNDERWOOD, THE CONSTITUTION OF SOUTH CAROLINA, VOL. II: THE JOURNEY TOWARD LOCAL SELF-GOVERNMENT (1989) (surveying South Carolina), the few published pieces in this area merely describe particular delegations, see Manning J. Dauer, Multi-Member Districts in Dade County: A Study of a Problem and a Delegation, 28 J. POL. 617 (1966); David R. Derge, Metropolitan and Outstate Alignments in llinois and Missouri Legislative Delegations, 52 AM. POL. SCI. REV. 1051 (1958). Perhaps this scholarly neglect derives from the fascination, or even the fixation, that many political scientists have with the United States Congress, see Lyn Ragsdale, Legislative Elections and Electoral Responsiveness, in HANDBOOK OF LEGISLATIVE RESEARCH 57 (Gerhard Loewenberg et al. eds., 1985) (hereinafter HANDBOOK], which leads these scholars to neglect the fertile field of local politics. In writing about delegations, I relied on both daily newspapers in Southern towns and interviews with local legislators and voters-two rich sources of information on local politics.

21. A recent lawsuit, Blanton v. Campbell, No. 2-91-3635-1 (D.S.C. amended complaint filed Dec. 12,1991 ), challenges the delegation system in South Carolina for reasons similar to some of those in this article. The federal district court has not yet ruled on the merits of the case. For a further discussion of Blanton, see infra notes 361-62, 461-464 and accompanying text.

22. Robert L. Morlan, Local Governments: An Embarrassment of Riches, in THE 50 STATES AND THEIR LOCAL GOVERMMENTS 505, 515 (James W. Fesler ed., 1967) [hereinafter 50 STATES]; see also GA. H. REP. R. 11. Counties are not the only political subdivisions represented by delegations. Some cities also have a legislative delegation that is a subset of the larger county delegation, including as members those legislators whose districts overlap with city boundaries. Cf. GA. H. REP. R. 11 (legislator eligible to vote if district "wholly or partially located within a political subdivision"). For an analysis recognizing city delegations as entities distinct from county delegations, see Jon $\mathrm{C}$. Teaford, Special Legislation and the Cities, 1865-1900, 23 AM. J. LEGAL HIST. 189, 207 (1979). See also infra notes 153-54 and accompanying text (comparing composition of delegations from Richmond County, Georgia and City of Augusta). For the sake of simplicity, and because both groups perform the same function, I refer to both types of delegations as legislative delegations.

23. See infra Part $\mathrm{I}(\mathrm{C})(1)$. In the nineteenth century, legislative delegations exercised broad authority in a number of states. Teaford, supra note 22. Although in some states the powers of delegations have diminished with the advent of home rule, UNDERWOOD, supra, note 20, at 199-200, 241, legislative delegations remain active in a number of southem states, including Alabama, see JAMES D. THOMAS \& WILLIAM H. STEWART, AlaBaMa GovernmeNT AND POLITICS 147-150 (1988); Florida, see Committee on Communi- 
extensive authority, delegations can have, and indeed have had, an especially adverse impact on minority voters. I conclude that a state's method of electing delegations should be cognizable under the Act. ${ }^{24}$

I use delegations as a lens for examining questions of voting power and the multiple ways in which politicians can manipulate and curtail it. ${ }^{25}$ These forms of manipulation are particularly significant in light of the current legislative reapportionments resulting from the 1990 census. The evidence establishes that legislatures have used reapportionment to discriminate against black voters by diminishing their influence in selecting the members of legislative delegations and by restricting the number of their chosen legislators who serve on those bodies. ${ }^{26}$ This pervasive discrimination effectively undermines many of the apparent gains black voters have made in electing black representatives to local governing bodies.

At the outset, I should note that my analysis of legislative delegations does not rely upon distinctions between sections $2^{27}$ and $5,{ }^{28}$ the two provisions

ty Affairs, Florida House of Representatives, Local Bill Policies and Procedures Manual (Dec. 2, 1991) (on file with author); Georgia, see EDWIN L. JACKSON \& MARY E. STAKES, HANDBOOK FOR GEORGIA LEGISLATORS 86-90 (10th ed. 1988); Mississippi, see United States v. Mississippi, 444 U.S. 1050, 1057 n.6 (1980) (mem.) (Marshall, J., dissenting), aff $g 490$ F. Supp. 569 (D.D.C. 1979); North Carolina, see MiCHAEL CROWELL, THE GENERAL ASSEMBLY OF NORTH CAROLINA: A HANDBOOK FOR LEGISLATORS 38-41 (5th ed. 1985); and South Carolina, see UNDERWOOD, supra note 20, at 199-200, 245. As a result, I focus on the way delegations operate in several Southern states-with a particular emphasis on Alabama, Georgia and South Carolina-to provide an overview of this phenomenon. In any event, a nationwide analysis of delegations would pose insurmountable difficulties because of the paucity of readily available information. See supra note 20 .

24. In voting rights terminology, "method of election" means the particular electoral mechanism by which a jurisdiction elects its officials-whether on an at-large basis, from districts, or by another variation. The method of election is simply one means of identifying the electorate that votes for a given office, see Presley v. Etowah County Comm'n, I12 S. Ct. 820, 828 (1992), and the term is also used to describe voting rules such as numbered place, majority vote, anti-single shot voting, and staggered term requirements. Here, I use the term to suggest that the means used to select delegations is a method of election in much the same way as are procedures used to elect formally constituted governing bodies. I also use the terms "structure" and "composition" when referring to methods of delegation selection.

25. My approach differs from a traditional doctrinal perspective that seeks to understand law exclusively through judicial opinions. As Professor Fischer notes with respect to the study of history, a synthesis of styles conveys the most powerful account of events. DAVID HACKETT FISCHER, ALBION's SEED vii-xi (1989) (comparative study of the use of narrative and political history). As a former voting rights attorney, I found that approaching theory "from the ground up" helped reveal both the richness and the failings of legal doctrine, as well as the way it works at its most basic level. As a clinical teacher, I encourage my students to take the same approach when representing clients. As scholarship, this approach follows in the footsteps of feminists and others who believe that law is best understood in context. See, e.g., Katherine T. Bartlett, Feminist Legal Methods, 103 HARV. L. REV. 829, 849-863 (1990) (explaining feminist practical reasoning); Patricia A. Cain, Feminist Jurisprudence: Grounding the Theories, 4 BERKELEY WOMEN's L.J. 191, 195-97 (1989-90) (describing relationship between feminist theory and feminist method).

26. See infra Part $\mathrm{II}(\mathrm{A})(3)$.

27. Section 2, Voting Rights Act of 1965, 42 U.S.C. $\$ 1973$ (1988). Section 2 provides:

(a) No voting qualification or prerequisite to voting or standard, practice, or procedure shall be imposed or applied by any State or political subdivision in a manner which results in a denial or abridgement of the right of any citizen of the United States to vote on account of race or color, or in contravention of the guarantees set forth in section $1973 b(f)(2)$ of this title [section $4(f)(2)$ of the original Act], as provided in subsection (b) of this section.

(b) A violation of subsection (a) of this section is established if, based on the totality of circumstances, it is shown that the political processes leading to nomination or election in the 
of the Act that are the major tools for voting rights enforcement. Although there are important differences between these statutory sections, ${ }^{29}$ a discussion of vote dilution's effect on local delegations does not implicate these distinguishing characteristics. ${ }^{30}$ Nor does the analysis depend on the much-discussed differences between discriminatory purpose and discriminatory effect. Sections 2 and 5 reach both types of discrimination, and delegations, like any other entity that implicates voting power, should be free from both forms of bias.

In Part I of this Article, I discuss the importance of legislative delegations in shaping the policies that govern the day-to-day lives of these legislators' constituents. While delegations perform a number of roles, their most critical function is their power to propose and pass local legislation. Delegations are the actual decisionmakers because legislatures rarely override delegation

State or political subdivision are not equally open to participation by members of a class of citizens protected by subsection (a) of this section in that its members have less opportunity than other members of the electorate to participate in the political process and to elect representatives of their choice. The extent to which members of a protected class have been elected to office in the State or political subdivision is one circumstance which may be considered: Provided, That nothing in this section establishes a right to have members of a protected class elected in numbers equal to their proportion in the population.

28. Section 5, Voting Rights Act of 1965, 42 U.S.C. $\$ 1973 \mathrm{c}$ (1988). Section 5 provides in pertinent part:

Whenever a State or political subdivision ... [covered under section 4] . . . shall enact or seek to administer any voting qualification or prerequisite to voting, or standard, practice, or procedure with respect to voting different from that in force or effect on ... [the applicable date of coverage] ... such State or subdivision may institute an action in the United States District Court for the District of Columbia for a declaratory judgment that such qualification, prerequisite, standard, practice, or procedure does not have the purpose and will not have the effect of denying or abridging the right to vote on account of race or color, or in contravention of the guarantees set forth in section $1973 \mathrm{~b}(\mathrm{f})(2)$... Iprotecting certain language minorities], and unless and until the court enters such judgment no person shall be denied the right to vote for failure to comply with such qualification, prerequisite, standard, practice or procedure: Provided, That such qualification ... may be enforced without such proceeding if the qualification ... has been submitted . . . to the Attorney General and the Attorney General has not interposed an objection within sixty days after such submission ....

29. The list of distinctions between the two provisions is long. For example, section 2 applies nationwide, while section 5 applies only to selected jurisdictions. Lani Guinier, No Two Seats: The Elusive Quest for Political Equality, 77 VA. L. REV. 1413, 1494 (1991). In contrast to section 2, under which litigants may challenge longstanding election arrangements, a jurisdiction covered by section 5 must change its voting practices to trigger the statute. See infra notes 437-41 and accompanying text. The burden of proof lies with the submitting jurisdiction proposing electoral changes under section 5, see City of Rome v. United States, 446 U.S. 156, 172 (1980), while plaintiffs in section 2 cases must show discrimination. Under the two sections, the measure of discriminatory effect differs, compare Beer v. United States, 425 U.S. 130 (1976) (section 5) with Thomburg v. Gingles, 478 U.S. 30 (1986) (section 2), although it has been argued that section 5 review requires jurisdictions to meet the mandates of both sections. Mark E. Haddad, Note, Getting Results Under Section 5 of the Voting Rights Act, 94 YALE L.J. 139 (1984).

30. The critical issue is whether delegations are functionally elected entities whose electoral practices merit the protective scrutiny of the Act. Regarding this question, section 2 and section 5 should be read in tandem. The Supreme Court relied on the "close connection" between the scope of the two sections in holding that judicial elections are covered under section 2, and noted that "[s]ection 5 uses language similar to that of $\S 2$ in defining prohibited practices...." Chisom v. Roemer, 111 S. Ct. 2354, 2367 (1991). See also Chisom v. Edwards, 839 F.2d 1056, 1064 (5th Cir.) ("[S]ection 5 and section 2, virtually companion sections, operate in tandem to prohibit discriminatory practices in voting, whether those practices originate in the past, present, or future."), cert. denied sub nom. Roemer v. Chisom, 488 U.S. 955 (1988). 
decisions. ${ }^{31}$ In order to demonstrate the ill effect of racial politics on legislative delegations, I first analyze three Voting Rights Act cases involving delegations. ${ }^{32}$ The first two consider the actions of present-day delegations, while the third discusses the functioning of a legislative delegation in the late nineteenth and early twentieth centuries. After tracing the historical origin of delegations and describing their current, wide-ranging power over local government, I explain the procedures local legislative delegations commonly follow and the "hands off" approach state legislatures have taken with respect to their operation. Then, I place these concepts in context through a case study of the delegation from Richmond County, Georgia.

In Part II, I analyze the development of voting rights jurisprudence as background for assessing the application of the Voting Rights Act to delegations. I examine three stages of the election process that have been challenged in voting rights litigation: (1) challenges at the pre-election and election-day stage to formal barriers to participation in the political process; (2) challenges at the vote dilution phase to electoral structures in which minority voters are unable to elect candidates to formal governing bodies; and (3) challenges at the post-election stage to governmental structures that impair the post-election influence of minority voters.

In Part III, I describe the discriminatory effect that methods of electing legislative delegations can have on black voters, given the vast power that the state legislature affords delegations. Based on the discussions of delegation powers in Part I and voting rights theory in Part II, I characterize delegations as elected governing bodies, or, alternatively, as integral players akin to legislative committees in the decisionmaking process of state legislatures. Because voting rights jurisprudence emphasizes formalism over functionalism, delegations do not seem to fit easily within existing formulations of voting rights. I conclude, however, that delegations are tantamount to superlegislatures for their local jurisdictions; that they fit squarely in the vote dilution stage; and that they should thus be considered cognizable under the Voting Rights Act.

To discuss the structure of legislative delegations, we must analyze the role of legislative reapportionments in the selection of delegation members, as well as the way the reapportionment revolution has affected the membership of delegations. ${ }^{33}$ Legislative reapportionments not only alter the composition

31. This relationship is particularly relevant to the question of whether delegations are elected entities whose structure can be examined under the Act.

32. McMillan v. Escambia County, 638 F.2d 1239 (5th Cir. Feb. 1981), cert. dismissed sub nom. Jenkins v. City of Pensacola, 453 U.S. 946 (1981) (dismissing city council petition only), vacated in part, 688 F.2d 960 (Former 5th Cir. 1982) (county commission), vacated and remanded, 466 U.S. 48 (1984); Brown v. Board of Comm'rs, 722 F. Supp. 380 (E.D. Tenn. 1989); Hardy v. Wallace, 603 F. Supp. 174 (N.D. Ala. 1985).

33. I borrow this term from GORDON E. BAKER, THE REAPPORTIONMENT REVOLUTION (1966). The term is used to describe the wide-ranging consequences stemming from the Supreme Court's mandate of one-person, one-vote through the process of revising legislative district lines. Reapportionment is by now a familiar part of the political landscape. Since Reynolds v. Sims, 377 U.S. 533 (1964), states are constitu- 
of the state legislature, but also modify the membership of each local delegation. Thus, delegation reapportionments may dilute the voting strength of minority voters, thereby implicating the Voting Rights Act. Empirical evidence from the recent round of legislative reapportionments suggests pervasive discrimination against black voters in the composition of delegations. Because existing doctrine does not adequately measure dilution in the delegation context, I propose a standard for measuring delegation dilution. I conclude Part III by discussing possible remedies for delegation dilution and the practical impact of taking delegations seriously under the Voting Rights Act.

In Part IV, I use delegations as a lens through which to examine more general questions of voting power. Like other elected bodies, delegations are assigned powers and duties, and they follow a set of rules and procedures. Through decisions to vest particular powers in delegations rather than local governments, or to divest delegations of jurisdiction, these bodies present numerous opportunities to manipulate legislative decisionmaking. A close look at both the rules governing delegation decisionmaking and the power-sharing relationship between delegations and state legislatures reveals that voting power can be frustrated as easily in the post-election stage as in the election stage of the political process. The doctrinal boxes that the Supreme Court has envisioned simply do not address the realities of practical politics, and are thus useless as vehicles for combatting voting discrimination. I conclude by suggesting that Congress should amend the Voting Rights Act so that the process of legislative decisionmaking can be examined, and reformed where necessary, by the courts.

\section{Legislative Delegations: A Functional ANAlysis}

Legislative delegations are deliberative bodies in state legislatures that introduce, consider, and either approve or disapprove local legislation for their respective counties. ${ }^{34}$ Local legislation is any legislative measure that applies only to a specific political subdivision within a state. ${ }^{35}$ In some states, local

tionally required to ensure that their legislative districts contain nearly equal numbers of people. Census counts measuring population shifts ensure that legislative reapportionments will occur at regular intervals. Thus, as a practical matter, states reapportion their legislative bodies every ten years after the decennial census, even though the Constitution does not require reapportionment after any particular period.

34. The procedures for considering local legislation differ from those for general legislation. See, e.g., JACKSON \& STAKES, supra note 23, at 85-86; see also infra notes $135-42$ and accompanying text. Furthermore, although delegations are primarily legislative entities, they also exercise nonlegislative powers.

35. Karl A. Bosworth, Policy Making, in 50 STATES, supra note 22, at 297, 307-08; see also DUANE LOCKARD, THE POLITICS OF STATE AND LOCAL GOVERNMENT 117 (2d ed. 1969) (describing history of local legislation). Local legislation is also referred to by a number of other terms, including "local acts," JACKsON \& STAKES, supra note 23, at 86; "Iocal laws," THOMAS \& STEWART, supra note 23, at 148; or "local bills," CROWELL, supra note 23 , at 38 . In some states, local legislation may affect more than one political subdivision, but must have less than statewide application. See, e.g., N.C. SEN. R. 39.1; N.C. H. REP. R. 35(b) (defining local legislation as legislation affecting fewer than fifteen counties). Local legislation should be distinguished from special legislation, which applies to private individuals or entities, not to political subdivisions. JACKSON \& STAKES, supra note 23, at 85; see also Bosworth, supra, at 308 (describing benefits and disadvantages of special legislation). Researching lecal legislation poses unique difficulties 
legislation comprises a significant portion of the laws adopted by the state. ${ }^{36}$ The structure of these delegations is thus critical to the success or failure of local initiatives.

A county's local legislative delegation is composed of those legislators whose districts include any portion of the county. ${ }^{37}$ Hence, membership on legislative delegations is determined by two factors: county boundaries and legislative district lines. ${ }^{38}$ Because county boundaries are virtually fixed, ${ }^{39}$ district lines, which change at regular intervals, are the critical factor in determining which legislators sit on a given delegation. ${ }^{40}$ If the county is entirely included within a single legislative district, then the delegation will consist of only one legislator. If the county is split between two legislative districts, on the other hand, two legislators will sit on the delegation. In short, each delegation consists of as many members as there are legislative districts in the political subdivision; ${ }^{41}$ as a result, some delegations are quite large. ${ }^{42}$

because, in many instances, facts can be unearthed only by reviewing session laws. In a few states, the legislature indexes local legislation by county and subject matter. See, e.g., STATE OF ALABAMA LOCAL LAWS INDEX (1986 \& annual updates); GA. CODE ANN. (Michie 1982 \& Supp. 1991) (local legislation index); S.C. CODE ANN. (Law. Co-op. 1976) (index to local laws).

36. JACKSON \& STAKES, supra note 23 , at 87 (reporting that more than half of all bills passed by Georgia legislature between 1970 and 1988 were local laws); CROWELL, supra note 23, at 38 (reporting that fifteen percent of bills currently introduced in North Carolina legislature are local laws). According to an earlier study of committee activity in the Alabama legislature between 1959 and 1965, the committees in the house of representatives responsible for local legislation considered more legislation and reported out a higher percentage of bills than any other committee; the same was true in the senate from 1961 through 1965. LEgISLATIVE REFORM STUDY COMMITTEE, IMPROVING THE ALABAMA LEGISLATURE 14-16 (1970).

37. See GA. SEN. R. 187; CROWELL, supra note 23, at 39; see also Duncan v. County of York, 228 S.E.2d 92 (S.C. 1976) (discussing composition of legislative delegations before and after the 1967 reapportionment required by Supreme Court eliminated South Carolina's one-county, one-senator system); infra notes 153-54 and accompanying text (discussing composition of Richmond County, Georgia delegation). Although each county has its own delegation, some legislators serve on more than one. Where a legislative district comprises more than a single county, the district's representative will serve on the delegations of as many counties as are included within the confines of the district. In 1991, for example, Georgia Senator Culver Kidd served on seven delegations. List of Local Legislative Delegations in Georgia (on file with author).

38. Similarly, the two determinants of city delegations are municipal boundaries and legislative district lines. See supra note 22.

39. Richard Briffault, Our Localism: Part I-The Structure of Local Government Law, 90 COLUM. L. REV. 1, 73 n.309 (1990) ("[T] lo location of county lines has remained virtually unchanged for decades."). Although a county can change its boundaries by merging or consolidating with an adjoining county, this is rare. See infra note 271 for an example of such an occurrence. A merger of a county with a city is a more common form of consolidation, but such mergers change only city boundaries while leaving county boundaries unchanged. For a general discussion of city-county consolidation, see LEE S. GREENE ET AL., THE STATE AND THE METROPOLIS 121-27 (1968). City boundaries are a more dynamic factor than county boundaries in determining delegation membership because of the greater potential for change in city boundaries. Cities can change their boundaries through consolidation, incorporation or annexation. Gayle Binion, Incident Survey and Analysis, 54 U. DET. J. URB. L. 695, 698 (1977).

40. See infra Part III(A)(3) (discussing discriminatory potential of this method of electing delegations). Because their membership is determined by legislative district lines, the composition of these delegations may be altered dramatically by the state legislative reapportionments required after the 1990 census.

41. The above analysis assumes a state that elects its members from single-member districts. For multimember district systems, the number of members elected from each district must be considered in computing the size of the delegation. 
This relationship between legislative district lines and delegation membership creates the opportunity for discrimination, while the critical role of delegations in local governance makes this discrimination profitable. This issue, racial politics in the exercise of delegation power, is addressed in the next Section.

\section{A. Racial Politics}

As the facts of Hardy v. Wallace $e^{43}$ powerfully demonstrate, legislative delegations have often been the objects of intense racial maneuvering aimed at undercutting their authority. At the same time, they have themselves perpetrated acts of racial discrimination, as is evident in McMillan v. Escambia County ${ }^{44}$ and Brown v. Board of Commissioners. ${ }^{45}$

Hardy concerned, among other things, greyhound racing in Greene County, Alabama. Until 1983, the three-member legislative delegation from Greene County was all white. ${ }^{46}$ One of the delegation's major powers was to appoint the county racing commissioners, who oversee greyhound racing at the local track. The racing commission, the county's largest employer, generated a majority of the county's tax revenue. ${ }^{47}$ Three days after a federal court approved a reapportionment plan that placed Greene County in two new legislative districts with black majorities-thereby creating the possibility of an entirely black delegation - the lame-duck delegation advertised local legislation transferring the authority to appoint the racing commission to then-Governor George Wallace. ${ }^{48}$ The legislature approved this change in procedure several

42. For instance, the delegation for Fulton County, Georgia (which includes Atlanta) has nineteen members; Beas Cutts, Clash Assured on House Remap, ATLANTA CONST., Aug. 26, 1981, at 1A; the delegation for Jefferson County, Alabama (which includes Birmingham) has eighteen members; Thomas B. Edsall, Racial Forces Battering Southern Democrats, WASH. POST, June 25, 1989, at A6.

43. 603 F. Supp. 174 (N.D. Ala. 1985).

44. 638 F.2d 1239 (5th Cir. Feb. 1981), cert. dismissed, 453 U.S. 946 (1981) (dismissing city council petition only), vacated in part, $688 \mathrm{~F} .2 \mathrm{~d} 960$ (5th Cir. 1982) (county commission), vacated and remanded, 466 U.S. 48 (1984).

45. 722 F. Supp. 380 (E.D. Tenn. 1989).

46. Political control of local government in Greene County had shifted from whites to blacks twelve years earlier, see David W. Coombs, et al., Black Political Control in Greene County, Alabama, 42 RURAL Soc. 398 (Fall 1977), and black leaders had persuaded investors to establish a greyhound racing track shortly thereafter, id. at 403. This shift of political control was "unprecedented" and "unique because it represents the first case of a total shift in [local] political decision-making power to blacks." Id. at 398. Despite black gains at the local level, whites controlled the delegation until 1983 because black voters were divided by legislative districting lines. Hardy, 603 F. Supp. at 179 (Appendix A) (reprinting Letter from William Bradford Reynolds, Assistant Attorney General, Civil Rights Division, United States Department of Justice, to Charles A. Graddick (June 18, 1984)). See Burton v. Hobbie, 561 F. Supp. 1029, 1032 n.8, 1033 (M.D. Ala. 1983).

47. Hardy, 603 F. Supp. at 175-76. In 1984, the county's unemployment rate was 18 percent and the revenue from the race track amounted to 63 percent of the county's budget. Id. at 176. In 1981, black leaders charged that the commission's hiring practices were racially discriminatory and protested the hiring of a commissioner with a poor record of employing blacks. UPI, Jan. 17, 1981, available in LEXIS, Nexis Library, UPI File (untitled).

48. Hardy, 603 F. Supp. at 176. See also Burton, 561 F. Supp. 1029 (approving Alabama reapportion- 
months later. After holding elections under the new reapportionment plan, the legislature rejected the newly elected black legislators' efforts to repeal the legislation. ${ }^{49}$

The court in Hardy held that the reallocation of authority to appoint racing commissioners from the delegation to the governor was cognizable under section 5 of the Voting Rights Act. The court reasoned that transfers of authority over an "agency of unique importance" to county voters from the delegation to the governor "substantially dilutes the power of the voters in Greene County by effectively eliminating [their power] over the Commission." exercised significant control over the commission through the delegation, but as less than one half of one percent of the state's residents, they could exercise relatively little influence on the governor. In effect, the maneuver transferred authority over regional matters from local voters to the electorate of the entire state..$^{51}$

The plaintiffs in Brown and McMillan, on the other hand, challenged the electoral structures adopted by their respective delegations. In McMillan, black voters challenged the method of electing the Escambia County school board. ${ }^{52}$ No black candidate had ever won election to the board, the members of which had been elected on an at-large basis since $1947 .^{53}$ In 1973 , the school board became embroiled in a controversy over the use of the nickname "Rebel" for the high school athletic teams. When black students challenged the nickname

ment). See infra note 133 for an explanation of the requirement of advertising local legislation.

49. Hardy, 603 F. Supp. at 176-77. The senate committee refused to report the bill introduced by the black legislators, an action that the district court described as "virtually without precedent." Id. at 177. The court noted that under the prevailing practice of "legislative courtesy," the Alabama legislature would "pass perfunctorily" all local bills to which members of the relevant delegations agreed. Id. at 176. For a more extensive discussion of the legislative courtesy rule, see infra notes 136-51 and accompanying text.

50. Hardy, 603 F. Supp. at 179 . The court did not actually find that the reallocation of authority discriminated against black voters because the court was not empowered to reach this question, since the statute vests authority for that decision in the United States Attorney General or in the United States District Court for the District of Columbia. See NAACP v. Hampton County Election Comm'n., 470 U.S. 166, 181 (1985). Under section 5, the Alabama federal district court had jurisdiction solely to determine whether the change was covered by section 5 .

51. Hardy, 603 F. Supp. at 179. The court distinguished the type of change in Hardy from the more typical case, noting that "[t]he most relevant attribute of the challenged act is its effect on the power of the voters rather than any aspect of the electoral process." Id. at 178. Although the majority in Presley did not cite Hardy, the Supreme Court effectively overruled Hardy's conclusion that voting power can be compromised by reallocating governmental authority. Presley v. Etowah County Comm'n, 112 S. Ct. 820, 829-30 (1992).

52. McMillan v. Escambia County, 638 F.2d 1239 (5th Cir. Feb. 1981), cert. dismissed sub nom. Pensacola v. Jenkins, 453 U.S. 946 (1981). Plaintiffs also challenged the method by which the Pensacola city council and the county commission were elected. Although the district court found all three systems to be unconstitutional, $i d$. at 1240 , the appellate court initially upheld these findings only with respect to the school board and the city council, id. at 1245, 1248-49. The court of appeals subsequently vacated the portion of its opinion concerning the county commission, 688 F.2d 960 (Former 5th Cir. 1982), and ultimately found that the commission's method of election violated the Voting Rights Act. 748 F.2d 1037 (Former 5th Cir. 1984), on remand from 466 U.S. 48 (1984), vacating 688 F.2d 960 (Former 5th Cir. 1982).

53. McMillan, 638 F.2d at $1240-41,1245$. 
by intervening in a pending school desegregation lawsuit, ${ }^{54}$ white students and parents intervened in defense of the nickname. After a protracted court battle, the board ultimately terminated use of the nickname "Rebel."

The local delegation responded by introducing local legislation in the state legislature designed to "pack" the school board. Among other things, the bill increased the size of the board from five to seven members and reduced the members' salaries.$^{56}$ In affirming the district court's finding that the county's entire system for electing board members was discriminatory, the court of appeals quoted the district court's finding that the delegation intended the board-packing episode to make the board "'more responsive to the white majority on a particular racially polarized issue [and to render] black voters politically impotent to the desires of the white majority."

Brown v. Board of Commissioners ${ }^{58}$ involved the efforts of the legislative delegation for Chattanooga, Tennessee to limit the growing influence of black voters in city elections during the late nineteenth and early twentieth centuries. During Reconstruction in Tennessee, as in the rest of the South, blacks obtained and exercised the right to register, vote, and run for public office..$^{59}$ Blacks were elected to the city's board of aldermen, and served as justices of the peace, constables, deputy sheriffs, and as members of the school board and the police and fire departments. In the early 1880 's, Chattanooga whites lobbied the legislative delegation to replace the city charter with a new document creating a "taxing district," most of whose officeholders would be appointed by the governor. As a compromise, the delegation instead imposed a poll tax, more restrictive voter registration procedures, and changes in the method of electing city aldermen. ${ }^{60}$

After these changes in the voting process failed to prevent black candidates from being elected to the board of aldermen, and when two blacks were elected to the state legislature during the 1880 's, the delegation turned to other discrim-

54. Augustus v. School Board, 361 F. Supp. 383 (N.D. Fla. 1973), modified in part, 507 F.2d 152 (5th Cir. 1975).

55. As described in McMillan, the district court enjoined the school board from using the name, and the court of appeals directed the district court to allow the school board to devise a solution. The school board decided to reinstate the term if two-thirds of the students voted in favor of it. When only a simple majority of students voted for the nickname, the school board resisted community pressure to revive the nickname. McMillan, 638 F.2d at 1246, n.13.

56. Id. at 1246. The bill had the delegation's unanimous support and passed overwhelmingly in a county referendum. The court of appeals explained the key role of the legislative delegation: "[C]hanges in local governments are submitted to the Florida Legislature through the local delegation, generally based on a resolution by the local government. As a practical matter, local legislation will pass the legislature if it has the unanimous support of the local delegation." Id. at 1246, n.14.

57. $I d$. at 1247 (quoting district court order). In many respects, the delegation was simply continuing a long tradition of discrimination. In 1959, the delegation had switched to at-large elections for the city council in order to prevent the election of black candidates. Id. at 1247-48.

58. 722 F. Supp. 380 (E.D. Tenn. 1989).

59. Kousser, supra note 7, at 28-30; WoODWARD, supra note 3, at 105-06.

60. Brown, 722 F. Supp. at 385-86. These revisions were accomplished through changes in the city charter intended to limit the electoral strength of black voters. 
inatory strategies over the next few decades. To reduce black political influence, the delegation increased the number of aldermanic wards in the city, created a bicameral city government, and gerrymandered the ward lines twice. ${ }^{61}$ Finally, in 1911, the county's legislative delegation passed a local bill adopting a commission form of government with commissioners elected on an at-large basis. ${ }^{62}$ The court in Brown found that the delegation, in adopting the commission form of government, was motivated in part by a discriminatory purpose ${ }^{63}$ and had as "an important goal ... the elimination of the last vestiges of black electoral power."

Although local delegations have operated as the moving force behind many discriminatory electoral structures, from at-large methods of election to suspect reapportionment plans, they have acted free of any real legal constraints. Unlike those of other governing bodies, the electoral structures of legislative delegations have not been challenged legally, ${ }^{65}$ and the true breadth of their powers has been largely ignored. The origins, powers and manner of operation of delegations are the subjects of the remainder of Part II.

\section{B. Origins of Delegations}

Local legislative delegations are the products of two closely related factors: the limited power of local governments and the historical emphasis on counties as the basic unit of representation in state legislatures. As state power over local governments grew, so did the states' corresponding need to find a mechanism for regulating local affairs. ${ }^{66}$ Although it is impossible to identify the precise moment at which legislative delegations came into existence, they had already become an important vehicle for state authority over localities by the late nineteenth century. ${ }^{67}$ Moreover, it is likely that racial factors also played a role in their creation. ${ }^{68}$

61. Id. at 386-87. At the time, the local newspaper announced that, as a result of one gerrymander, "the negroes of Bushtown, Stanleyville and Churchville are about the nearest disfranchised they could possibly be." Id. at 387 .

62. Id. at 387. The local newspaper predicted that the success of the movement for commission government would cause the political downfall of Hiram Tyree, a prominent black leader ("his light promises to go out forever.") Id. By making it illegal to pay another voter's poll tax and eliminating "ward workers," the charter change further disfranchised black voters. Id.

63. Id. at $389,397$.

64. Id. at 387. No black candidate was elected to the City Commission until 1971, 60 years after the commission form of government was adopted. Id. at 387-88.

65. The sole exception is apparently the recently-filed litigation in South Carolina, discussed supra note 21 .

66. See Terrance Sandalow, The Limits of Municipal Power Under Home Rule: A Role for the Courts, 48 MINN. L. REV. 643, 647 (1964).

67. Discussions of these early legislative delegations can be found in Brown, 722 F. Supp. at 386 (discussing Chattanooga, Tennessee delegation in early 1880's) and Jackson v. Edgefield County Sch. Dist., 650 F. Supp. 1176, 1180 (D.S.C. 1986) (discussing South Carolina delegations in 1890's).

68. See infra notes $94-95$ and accompanying text. 
When states have limited the "home rule" authority of local governing bodies to enact legislation, ${ }^{69}$ they usually have developed procedures that leave the responsibility for introducing, considering, and passing local legislation to legislative delegations. The role of delegations is thus influenced in large part by the limits of home rule. ${ }^{70}$

Because local governments ${ }^{71}$ derive their limited, delegated powers entirely from the states, they exercise authority as agents of the states, ${ }^{72}$ which grant home rule to local jurisdictions through state constitutions and implementing legislation. Localities, in turn, amend their charters to reflect the expansion of state-granted powers. The local governments may then enact laws and ordinances and provide for administrative and executive functions free from state interference. ${ }^{73}$ The degree of home rule that states afford to localities thus circumscribes state involvement in local affairs. ${ }^{74}$ Although all states provide for some measure of home rule, the degree of control retained by state govern-

69. The term "home rule" delineates the division of power between state and local governments and the discretion exercised by local government without interference from the state. See, e.g., Briffault, supra note 39, at 6-11; Robert L. Morlan, Local Governments-The Cities, in 50 STATEs, supra note 22, at 467; LOCKARD, supra note 35 , at $120,122$.

70. See JACKSON \& STAKES, supra note 23, at 86; LOCKARD, supra note 35, at 117; THOMAS \& STEWART, supra note 23, at 150; Bosworth, supra note 35, at 307-08; Richard Briffault, Our Localism: Part Il-Localism and Legal Theory, 90 CoLUM. L. REv. 346, 358 (1990) (describing home rule as constraint on legislative involvement in local affairs).

71. The term "local government" includes towns, cities, counties and special district governments. Morlan, supra note 22, at 517-31. Although most of the literature on home rule discusses municipalities, see LOCKARD, supra note 35, at 116-24, the discussion in this Section does not distinguish between home rule for municipalities and other political subdivisions. In the South, counties are the basic unit of local government. Id. at 102. Historically, states have played an active role in the formation and expansion of local governments. Briffault, supra note 70, at 357-58. Two extreme examples of the reverse phenomenon are provided by the Alabama and Tennessee legislatures, which abolished the cities of Mobile and Memphis in the 19th century. Allan R. Richards, The Heritage of the Eighteenth and Nineteenth Centuries, in 50 STATES, supra note 22 , at 67.

72. For an excellent general discussion of this principle, see Briffault, supra note 70; see also LOCKARD, supra note 35, at 116-24; Harvey C. Mansfield, Intergovernmental Relations, in 50 STATES, supra note 22, at 178. In fact, the Supreme Court relied on the exercise of these delegated powers by local governing bodies as the basis for extending the one-person, one-vote principle to local legislative elections. See Avery v. Midland County, 390 U.S. 474, 478-79 (1968).

73. C. DALlas SANDS ET AL., LOCAL GOVERNMENT LAW $\$ 4.07$ (1991 \& Supp.).

74. States, of course, retain the power to change the terms of self-government granted to localities. Hunter v. Pittsburgh, 207 U.S. 161 (1907). Georgia is a case in point. In 1945, Georgia adopted a new constitution providing for mandatory home rule. The legislature passed, repealed, and later re-adopted enabling legislation for the home rule provisions. The state supreme court found the enabling legislation adopted by the legislature unconstitutional. A new constitutional provision providing for home rule was adopted in 1954, but legislation implementing this provision was not adopted until 1966. LOCKARD, supra note 35, at 121; J. DEVEREAUX WEEKS, INVENTORY OF GENERAL HOME RULE \& REVENUE POWERS OF MUNICIPAL CORPORATIONS IN GEORGIA 1 (1984). The Constitution was again revised in 1972 to give cities and counties additional powers. Id. 
ments varies substantially. ${ }^{75}$ When states have limited the authority of local government to act, it typically has been in the legislative arena. ${ }^{76}$

Legislative delegations also derive from the historical emphasis on counties as the basic unit of representation in state legislatures. ${ }^{77}$ Before the one-person, one-vote principle ${ }^{78}$ became the basis for apportioning state legislatures in the early 1960's, legislators in most states were elected from legislative districts consisting of a single county, or a larger district that included two or more counties in their entirety. ${ }^{79}$ Regardless of the apportionment structure used, districts generally did not cross county lines. ${ }^{80}$ Under this arrangement, each county was effectively guaranteed representation in the state legislature on matters of statewide concern. ${ }^{81}$

Counties also provided a ready mechanism for states to exercise the powers states retained over local matters. ${ }^{82}$ Because legislative district lines generally

75. See generally ANTIEAU, supra note 20 , at ch. 3 . For example, states diverge concerning the authority accorded cities over their charters. In some states, cities may adopt their own charters; in others, state law either assigns charters to cities depending upon the class of the city or provides the locality with a choice between several alternative charters. LOCKARD, supra note 35, at 116-17, 121.

76. See Ellen J. Alexander, Home Rule Expansion But at What Cost?, 13 URB. LAW. 765 (1981) (reviewing state court challenges to legislative acts of local governments); George D. Vaubel, Toward Principles of State Restraint Upon the Exercise of Municipal Power in Home Rule, 20 STETSON L. REV. 845, 853-59 (1991) (describing division of legislative power between state and local governments).

77. Donald O. Bushman \& William R. Stanley, State Senate Reapportionment in the Southeast, 61 ANNALS Ass'N AM. GEOGRAPHERS 654,655-56 (1971); Paul T. David, Issues and Problems in Redistricting State Legislatures, in EVOLVING IsSUES AND PATTERNS OF STATE LEGISLATIVE REDISTRICTING IN LARGE METROPOLITAN AREAS 105 (Morris W.H. Collins, Jr. et al. eds., 1966).

78. See infra notes $282-95$ and accompanying text for the impact of equal population principles on the structure of delegations.

79. Robert Dixon's classic work provides an account of legislative reapportionment in the period before equal apportionment was the rule. DIXON, supra note 17. In the 19th century, states allocated seats to political subdivisions, while giving some recognition to the principle that more populous counties deserved a greater number of seats in the legislature. $I d$. at 82 . In the 20 th century, states moved towards a "federal" principle of apportionment that emphasized county equality in one house of the legislature and population apportionment in the other house. Id. at 82,86 (showing in chart 4 apportionment formula for state legislatures as of Juiy 1, 1961); NATIONAL MUNICIPAL LEAGUE, APPORTIONMENT IN THE NINETEEN SLTIIES (1970) (summarizing status of state and congressional legislative apportionments following one-person, onevote); THE INSTITUTE OF GOVERNMENT, REAPPORTIONMENT IN GEORGLA (1970) (describing Georgia's reapportionment scheme); Preston W. Edsall, North Carolina: People or Pine Trees, in THE POLmics of REAPPORTIONMENT 98 (Malcolm E. Jewell ed., 1962) (describing North Carolina's apportionment scheme).

80. See Davis v. Mann, 377 U.S. 678, 686 (1964) (noting "tradition of respecting the integrity of the boundaries of cities and counties in drawing district lines"). In many instances, state constitutions contained prohibitions against creating legislative districts that crossed county lines. See, e.g., ALA. CoNST. art. IX, $\S 200$; IND. CONST. art. 4, § 6 (repealed 1984). Rarely were counties divided into more than one district. In Southern states, it was common for counties entitled to elect more than one senator or representative to elect these legislators on a countywide basis, MALCOLM E. JEWELL, LEGISLATIVE REPRESENTATION IN THE CONTEMPORARY SOUTH 39-40 (1967) [hereinafter JEWELL, CONTEMPORARY SOUTH] (giving as examples Florida, Alabama, Louisiana, North Carolina, South Carolina and Tennessee), rather than from singlemember districts. See also Davis, 377 U.S. at 686; Malcolm E. Jewell, How Many Members?, 57 NAT'L. CIVIC REV. 75 (1968).

81. Malcolm E. Jewell, Political Patterns in Reapportionment, in THE POLITCS OF REAPPORTIONMENT, stpra note 79, at 8; Bill Kovach, Some Lessons of Reapportionment, 37 REPORTER, Sept. 21, 1967, at 26, 31-32.

82. Reynolds v. Sims, 377 U.S. 580,581 (1964) (observing that preservation of political subdivision boundaries makes enactment of local legislation easier). 
conformed to county boundaries, ${ }^{83}$ a close "fit" between membership on a delegation and connection to county affairs was almost automatic. ${ }^{84}$

County-based representation was an especially common phenomenon in the South. ${ }^{85}$ In many Southern states, delegations operated as a kind of superlegislature for their respective counties, their powers enhanced by their operating procedures. Rather than having the state legislature as a whole consider issues that interested very few people outside of the affected county, the states delegated this responsibility to the county legislative delegations. ${ }^{86}$ State legislators elected from a county sat as members of its delegation and reviewed local legislation affecting the region. A delegation typically approved legislation if its members unanimously supported it. ${ }^{87}$ The customary practice of state legislatures was to enact legislation passed by the delegations and to decline to adopt local bills that lacked delegation approval. This practice became known as "local (or legislative) courtesy." 88

South Carolina best illustrates the operation of local legislative delegations in a setting where local jurisdictions had little home rule authority and counties were the basic unit of representation in the state legislature. Although legislative delegations in many Southern states historically have exercised broad powers, the dominance of South Carolina delegations over local government was

83. This system stands in sharp contrast to contemporary legislative delegations, in which district lines often resemble a jigsaw puzzle. See infra Part III(A)(2).

84. In multi-county districts, most common in state senates, the delegation member often resided outside of the affected county, but nonetheless decided matters of purely local concern. In the South, this awkward arrangement was tempered by the use of rotation agreements, in which each county in a multicounty district took a tum at electing the senator from the district. DIXON, supra note 17, at 514; JEWELL, CONTEMPORARY SOUTH, supra note 80, at 23-24 (noting that Alabama, Kentucky, Tennessee and North Carolina employed rotation agreements). Voters could only cast ballots in the primary when it was their turn to select officials. CULLEN B. GOSNELL \& C. DAVID ANDERSON, THE GOVERNMENT AND ADMINISTRATION OF GEORGIA 51 (1956). Because winning the primary was tantamount to election at that time, these gentlemen's agreements in effect guaranteed each county a resident senator at regular intervals. Rotation agreements are no longer used and would likely violate one-person, one-vote standards. Toombs v. Fortson, 205 F. Supp. 248, 257 (N.D. Ga. 1962) (holding rotation agreements unconstitutional); DIXON, supra note 17, at 514. The implications of multicounty districts for the analysis of present day delegations is discussed infra notes 300 02,434 and accompanying text.

85. Bushman \& Stanley, supra note 77, at 655-56. Georgia demonstrated an especially high regard for county representation through its peculiar county unit system. DIXON, supra note 17, at 173-74 (describing Gray v. Sanders, 372 U.S. 368 (1963)); THE INSTITUTE OF GOVERNMENT, supra note 79, at 7; William G. Cornelius, The County Unit System of Georgia: Facts and Prospects, 14 W. PoL. Q. 942 (1961); Jewell, supra note 81 , at 21.

86. GOSNELL \& ANDERSON, supra note 84, at 31; LOCKARD, supra note 35 , at 118 ; Teaford, supra note 22 , at $190,192,196-99$.

87. Carrollton Branch of NAACP v. Stallings, 829 F.2d 1547 (11th Cir. 1987), cert. denied sub nom. Duncan v. City of Carrollton, 485 U.S. 936 (1988). The so-called "unanimity" rule is now the exception rather than the rule. See infra notes 148-51 and accompanying text for the implications of this change.

88. See Morlan, supra note 22, at 515; Sandalow, supra note 66, at 656 . For an interesting account of the operation of the local courtesy rule in Alabama, see HALLIE FARMER, THE LEGISLATIVE PROCESS IN ALABAMA 248 (1949) ("[C]ourtesy and usage of the House or Senate leave [legislators] no alternative but to support any measure which has the endorsement and sanction of the local member.") (quoting former state legislator Emmet $\mathrm{O}^{\prime} \mathrm{Neal}$ ). This practice remains substantially unaltered today. See infra notes 135-47 and accompanying text. 
unique. ${ }^{89}$ Before the implementation of home rule in $1975,{ }^{90}$ South Carolina's local legislative delegations performed most governmental functions for counties and municipalities. ${ }^{91}$ The delegations enacted "local supply bills" which levied taxes on county residents and set each county's budget. The county treasurer disbursed funds only after receiving a letter from the delegation signed by the county's state senator and a majority of the county's state representatives. ${ }^{92}$ Each delegation also appointed the members of its county's local governing body, whose duties were primarily administrative and ministerial. ${ }^{93}$

In addition to concerns about home rule and county representation, racial factors also may have played a role in creating and developing local legislative delegations. In South Carolina, for example, evidence suggests that Governor Tillman, an avowed white supremacist, replaced local government structures with delegations to limit growing black political strength. ${ }^{94}$ Certainly, many political developments in the South can be traced to a desire to ensure blacks' political impotence. ${ }^{95}$ But because delegations have received little attention from scholars, the historical record is incomplete.

Delegations, by empowering the state in local matters while still allowing for local administration, could also serve as tools for discrimination. By delegating to local state legislators virtually plenary authority over administrative decisions and bills of local import, the state kept control over those issues out

89. COLUMBUS ANDREWS, ADMINISTRATIVE COUNTY GOVERNMENT IN SOUTH CAROLINA 34-46 (1933); WALTER BASS \& JACK DEVRIES, THE TRANSFORMATION OF SOUTHERN POLITICS: SOCIAL CHANGE AND POLITICAL CONSEQUENCE SINCE 1945, at 276-81 (1976); V.O. KEY, JR., SOUTHERN POLITICS IN STATE AND NATION 151-52 (new ed. 1984); Peyton McCrary \& J. Gerald Hebert, Keeping the Courts Honest: The Role of Historians as Expert Wimesses in Southern Voting Rights Cases, 16 S.U. L. REV. 101, 113 (1989). The role of legislative delegations in South Carolina during this period is discussed in a number of cases filed under the Voting Rights Act. See, e.g., McCain v. Lybrand, 465 U.S. 236 (1984); Jackson v. Edgefield County, 650 F. Supp. 1176 (D.S.C. 1986); County Council of Sumter County v. United States, 555 F. Supp. 694 (D.D.C. 1983) (dismissing summary judgment motion), 596 F. Supp. 35 (D.D.C. 1984) (opinion after trial on merits); Blanding v. Dubose, 509 F. Supp. 1334 (D.S.C. 1981), rev'd on other grounds, 454 U.S. 393 (1982) (per curiam); Woods v. Hamilton, 473 F. Supp. 641 (D.S.C. 1979); Horry County v. United States, 449 F. Supp. 990 (D.D.C. 1978).

90. The Home Rule Act, S.C. CODE ANN. \& 5-9-10 (Law. Co-op. 1976), gave counties increased authority over local affairs and permitted county voters to hold a referendum to select one of five altemative forms of local government. See County Council of Sumter, 596 F. Supp. at 37.

91. Blanding, 454 U.S. at 395; Woods, 473 F. Supp. at 643. These functions included legislative, executive, and taxing powers. Horry County, 449 F. Supp. at 993.

92. Horry County, 449 F. Supp. at 993.

93. McCain, 465 U.S. at 239 (explaining that Edgefield County Board of Commisioners had "limited administrative and ministerial powers"); Blanding, 509 F. Supp. at 1335 (describing Sumter County Board of Supervisors as "ministerial and supervisory body").

94. See Laughlin McDonald, An Aristocracy of Voters: The Disfranchisement of Blacks in South Carolina, 37 S.C. L. REV. 557, 569-70 (1986). Similar developments occurred after Reconstruction in Virginia, Kousser, supra note 7, at 36, and in Alabama, where elective local govemment in several black belt counties was replaced with appointive government, J. Morgan Kousser, How to Determine Intent: Lessons from L.A., 7 J.L. \& POL. 591, 709 (1991) [hereinafter Kousser, How to Determine Intent]. As one Alabama legislator exhorted, "[w]hen we saw the life, liberty and property of the Causcasians were at stake, we struck down in Dallas County the Negro and his cohorts. We put men of the Caucasian race there to try them." Kousser, supra note 7, at 36 (quoting state legislator James Jefferson Robinson).

95. See generally, Kousser, supra note 7. 
of the hands of local governmental officials. Although blacks stood little chance of gaining any elective office whatsoever during this period of suffrage restrictions, such a victory was more likely at the local level than in the statewide arena. ${ }^{96}$ Furthermore, if by some chance blacks (or their sympathizers) achieved electoral success in a state legislature, the legislature could nevertheless control a renegade delegation by ignoring local courtesy and overruling such a panel's decisions. These maneuvers could effectively suppress any stirrings of black political activity while permitting delegations, rather than the state itself, to manage the affairs of local government.

\section{Contemporary Developments}

\section{Local Government Powers}

Legislative delegations in many Southern states continue to exercise a wide variety of prerogatives over the affairs of local government. As superlegislatures for their cities and counties, delegations introduce and enact local legislation; they serve as the de facto decisionmakers because state legislatures routinely affirm their decisions. ${ }^{97}$ Although issues vary from state to state, local legislation is particularly significant in six general areas: the structure of local government; changes in the boundaries of political subdivisions (through annexation, incorporation, and consolidation); election administration; education; appointments of public officials; and revenue-raising. ${ }^{98}$ Local legislation also often governs a variety of other local matters, including the creation of the local bureaucracy and the compensation of its members, ${ }^{99}$ the distribution of license plates, ${ }^{100}$ mass transit ${ }^{101}$ and racing. ${ }^{102}$

96. Id. at 39. Even today, most black officeholders are elected at the local level. See JOINT CENTER FOR POLITICAL AND ECONOMIC STUDIES, BLACK ELECTED OFFICIALS: A NATIONAL ROSTER (1990).

97. The delegations' authority in the legislative process is further explained infra notes $135-42$ and accompanying text.

98. Typically, limitations on the content of local legislation are expressed negatively as descriptions of what local legislation cannot address, rather than descriptions of the permissible scope of local legislation. For a representive sample of such limitations, see ALA. CONST. art. IV, § 104; GA. CoNST. art. 3, § 6, § 4; MISs. CONST. art. 4, § 90; N.C. CONST. art. II, $\$ 24$; S.C. CONST. art. 3, $\$ 34$. For a general description of limits on the scope of local legislation, see Edward M. Kresky, Local Government, in SALIENT ISSUES OF CONSTITUTIONAL REvision 150, 155-56 (John P. Wheeler, Jr. ed., 1961). Moreover, some state constitutions permit "local" constitutional amendments that set forth limits on the scope of legislation for particular counties and their subdivisions. See, e.g., ALA. CONST. amends. 140, 144, 255. As with general constitutional amendments, these amendments may be repealed. See ALA. CoNST. amend. 337 (repealing amend. 184).

99. See ALA. CONST. amend. 297; THOMAS \& STEWART, supra note 23, at 149; WEEKS, supra note 74, at 3; Judge Okays Raises for Seminole Officials, UPI, Jan. 26, 1986, available in LEXIS, Nexis Library, UPI File (legislative delegation controls salaries of local probate judge, clerk of court, and tax commissioner); Tax Protests Costly, UPI, Mar. 25, 1983, available in LEXIS, Nexis Library, UPI File (state court judges plan to ask Cobb County, Georgia delegation to eliminate state court judgeship and create two superior court judgeships).

100. See UPI, Apr. 30, 1985, available in LEXIS, Nexis Library, UPI File (untitled) (discussing Georgia license plate distribution program). 
With respect to the structure of local government, the form of government and method of election for local governing bodies ${ }^{103}$ must be established by local legislation in states that have not granted counties and municipalities the authority to make such decisions themselves. ${ }^{104}$ For example, county voters wishing to change the method for electing the county governing body from atlarge to single-member district elections must seek the approval of the legislative delegation. ${ }^{105}$ Similarly, to switch from an appointed to an elected school board would require local legislation. ${ }^{106}$ In addition, local legislation is needed to effect changes in the boundaries of political subdivisions. ${ }^{107}$ Municipal boundaries are altered by annexation and incorporation, as well as by the merger of city and county governments through consolidation. ${ }^{108}$ Such changes often require the approval of the relevant legislative delegations.

Delegations also play a role in the appointment of individuals to public office. Their authority often includes the power to appoint "local" members of

101. See UPI, Feb. 26, 1981, available in LEXIS, Nexis Library, UPI File (untitled) (Birmingham, Alabama (Jefferson County) bus system shut down when delegation refused to fund system); see also Greenville Exempted from Transit Bill, UPI, June 5, 1985, available in LEXIS, Nexis Library, UPI File (fare increases for local transportation systems in South Carolina).

102. See Rogers Continues to Push Sunday Racing Bill, UPI, June 23, 1987, available in LEXIS, Nexis Library, UPI File (Jefferson County, Alabama delegation introduced bill to permit horse racing on Sunday); UPI, Jan. 17, 1981, available in LEXIS, Nexis Library, UPI File (untitled) (Greene County, Alabama delegation appointed member to local racing commission).

103. For a definition of method of election, see supra note 24.

104. Duncan v. County of York, 228 S.E.2d 92, 96 (S.C. 1976). This area has particular significance for the Voting Rights Act because governmental structures can have a significant impact on the ability of black voters to influence the political process. Chandler Davidson, Minority Vote Dilution: An Overview, in MENORITY VOTE DLUTION, supra note 7, at 5-9 (idenifying structures that dilute minority voting strength). In fact, home rule is sometimes equated with the ability of a political subdivision to define its form of government. See City of Lockhart v. United States, 460 U.S. 125, 127 (1983). In many states, local governments have only limited authority to change their forms of government and methods of election. See Richards, supra note 71 , at 67 n.32.

105. Newspaper reports convey a clear picture of the crucial importance of delegations in this process. In Blakely County, Georgia, the attorney representing black plaintiffs in a lawsuit challenging the at-large method of electing the city council condemned the legislative delegation for "intentionally [choosing] to retain the discriminatory system." Blacks Challenge Voting System They Call Discriminatory, UPI, Apr. 30, 1990, available in LEXIS, Nexis Library, UPI File. In Gwinnett County, Georgia, the local district attorney requested the delegation to change the county manager's appointed position into an elected office. Gwinnett DA Asks for Elected County CEO, UPI, Dec. 13, 1988, available in LEXIS, Nexis Library, UPI File (alleging that county commissioners violated ethical rules in appointing current county manager). In Lee County, Alabama, the delegation refused the request of local blacks to increase the county commission from four to five members in order to make it possible to elect a black member to the commission. Alabama News Briefs, UPI, Feb. 20, 1986, available in LEXIS, Nexis Library, UPI File. See infra notes 162-73, 18893 and accompanying text for the controversy surrounding the Richmond County, Georgia delegation's proposal to switch from at-large to ward voting for the city council.

106. J.L. Chestnut, a black activist from Selma, Alabama, discusses the disturbing role of a local allwhite delegation in fashioning a method of school board selection that perpetuated white control. J.L. ChestNuT, JR. \& JULIA CASS, BLACK IN SELMA 291 (1990).

107. See, e.g., Opinion of the Justices No. 268, 381 So. 2d 632, 634 (Ala. 1980); Abbott v. Town of Highlands, 277 S.E.2d 820, 824 (N.C. Ct. App. 1981). See infra notes $159-93$ and accompanying text for a discussion of the Richmond County delegation's efforts to merge the city of Augusta with Richmond County by local legislation. The petition method is an alternative way to annex territory. See infra note 174 and accompanying text.

108. Binion, supra note 39 , at 698 . 
various state boards, ${ }^{109}$ as well as members of local boards and commissions. ${ }^{110}$ In the area of elections, for example, delegations are often responsible for appointing members to local election commissions. ${ }^{111}$ These election officials in turn appoint poll officials to supervise the polling places and to conduct election day activities for general elections in the county. ${ }^{112}$ Through the power to select election commissioners, delegations can significantly influence the conduct of elections in each county. Delegations can also establish judicial offices ${ }^{113}$ and participate in the appointment of individuals to midterm judicial vacancies. ${ }^{114}$

109. Palmetto Perspective, UPI, Feb. 14, 1982, available in LEXIS, Nexis Library, UPI File (discussing South Carolina State Highway Commission).

110. See, e.g., S.C. CoDE ANN. \$ 4-27-520 (Law. Co-op. 1986) (county planning commissions); Opinion of the Justices, 373 So. 2d 1051 (Ala. 1979) (waterworks board); Dekalb Orders Budget Cuts Up to 24 Percent, UPI, May 20, 1987, available in LEXIS, Nexis Library, UPI File (committee to study county budget); Woman Rewarded for Contributions, UPI, May 1, 1984, available in LEXIS, Nexis Library, UPI File (members of local airports authority); UPI, Jan. 5, 1983, available in LEXIS, Nexis Library, UPI File (untitled) (panel to study alternatives to weekend closing of University of South Alabama Medical Center); UPI, Mar. 19, 1982, available in LEXIS, Nexis Library, UPI File (untitled) (members of civic center authority); $c f$. S.C. CODE ANN. § 43-3-10 (Law. Co-op. 1986) (members of county boards of social services appointed by governor upon recommendation by delegation majority). The role of delegations in making appointments to these bodies varies from state to state, and in some instances, from county to county. For South Carolina counties that have adopted the county board of commissioners form of government, all appointments to boards, committees, and commissions in the county are made by the governor on the recommendation of the legislative delegation. S.C. CODE ANN. § 4-9-1100 (Law. Co-op. 1986). For a discussion of delegation authority to appoint school board members, see infra note 119.

111. See, e.g., S.C. CODE ANN. \& 7-13-70 (Law. Co-op. 1976 \& Supp. 1991) (delegations recommend county election commissioners for appointment by governor); State GOP Supports State-Run Primaries, UPI, Feb. 18, 1985, available in LEXIS, Nexis Library, UPI File (delegations given appointment authority in legislative proposal to add two members to each county election commission). Even where delegations only have the formal power to recommend individuals for appointment, they often, as a practical matter, possess the actual authority over these local appointments. See S.C. CODE ANN. § 4-11-30 (Law. Co-op. 1986) (delegation selection automatic in certain South Carolina counties where governor fails to act within 10 days). A governor typically would have little interest in overriding a delegation's recommendation.

112. See, e.g., S.C. CODE. ANN. \$ 7-13-70 (Law. Co-op. 1976 \& Supp. 1991) (specifying duties of election commissioners); S.C. CODE. ANN. \$\$ 7-13-1420 to 7-13-1460 (Law. Co-op. 1976) (specifying duties of various poll officials). In South Carolina, election commissioners also have duties in municipal annexation proceedings. S.C. CODE ANN. \$\$ 5-3-50 to 5-3-80 (Law. Co-op 1976 \& Supp. 1991). Because most elections-including federal and state elections-are conducted at the county level, the conduct of these election officials is a critical component of the electoral process. See Jackson v. Edgefield County Sch. Dist, 650 F. Supp. 1176, 1182-83 (D.S.C. 1986) (explaining importance of minority poll officials to minority political participation).

113. 1984 GA. LAws 776 (authorizing chief magistrate for Bryan County); 1988 S.C. ACTS 758 (authorizing magistrates for Aiken County, South Carolina); Tax Protests Costly, UPI, Mar. 25, 1983, available in LEXIS, Nexis Library, UPI File (elimination and creation of Georgia judgeship); Joan Kirchner, Legislature: Freeways and Funding Grab Annexation's Glory in 1986, AUGUSTA CHRON., Jan. 5, 1986, at $\mathrm{IE}, 4 \mathrm{E}$ (same). In South Carolina, delegations also determine other aspects of magistrate positions. For example, the Aiken County delegation is involved in choosing the office location for magistrates. 1988 S.C. Acts 758. For a listing of local laws relating to magistrates, see S.C. CODE ANN. \& 22-1-10 (Law. Co-op. 1989) (listing related local laws).

114. 1976 S.C. ACTS 528 (vacancy on Union County court filled by governor on recommendation of legislative delegation). 
Delegations also play an important role in financing local government. ${ }^{115}$ Local tax increases (of school taxes, special sales taxes, and other taxes) ${ }^{116}$ and the imposition of certain business license fees are implemented through local legislation. In other instances, delegations control the disbursement of funds for local projects. ${ }^{117}$

The pervasive influence of local legislative delegations is often most visible in their control over local education. In addition to possessing the authority to determine how local school boards are selected, ${ }^{118}$ some delegations choose the members of appointed school boards. ${ }^{119}$ The delegations' involvement in local education is often even more extensive, however. In some jurisdictions, county boards of education cannot alter or divide school districts without the written approval of their respective legislative delegations. ${ }^{120}$ In others, school districts have no taxing authority, and school district revenue is raised through local legislation. ${ }^{121}$

In addition to their formal responsibility for enacting legislation, delegations also play a less formal role similar to that of interest groups or caucuses in the

115. The exercise of revenue-raising powers through local legislation in Georgia is described in WEEks, supra note 74, at 6-10. See also Abbott v. Town of Highlands, 277 S.E.2d 820, 824 (N.C. App. 1981) (quoting Lutterloh v. Fayetteville, 62 S.E. 758, 760 (N.C. 1908)).

116. See, e.g., Charlotte Groups Protest Tax Proposal, UPI, Nov. 30, 1988, available in LEXIS, Nexis Library, UPI File (bill authorizing 50\% seat tax for Charlotte, North Carolina); Gasoline Tax to be Voted, UPI, Feb. 20, 1985, available in LEXIS, Nexis Library, UPI File (bill authorizing gasoline tax referendum in Jackson County, Alabama); These Businesses Tax Themselves, GEORGLA TREND (Jan. 1989), \$1, at 17 (bill authorizing special tax district in Cobb County, Georgia). See infra note 121 and accompanying text for a discussion of delegations' role in financing education.

117. See, e.g., Hoyt Coffee, House Debates Raising Bingo Fees, UPI, March 11, 1987, available in LEXIS, Nexis Library, UPI File (South Carolina recreational programs); Linda Kuntz Logan, UPI, July 10, 1981, available in LEXIS, Nexis Library, UPI File (South Carolina road projects).

118. For an instance of control by an all-white delegation over a school board, see supra note 106.

119. See S.C. CODE ANN. \$ 59-15-10 (Law. Co-op. 1976) (providing that members of certain county education boards are appointed by govemor following delegation recommendation). As of 1986, thirteen South Carolina school boards were appointed by majority-white delegations. Dudley Clendinen, White Grip on Southern Schools: Keeping Control, N.Y. TMMES, June 23, 1986, at A10. Only three of these school boards had a black majority. Id. Moreover, delegations' powers are not limited to local education. County delegations in South Carolina appoint members of the State Board of Education from their respective judicial circuit, S.C. CODE ANN. \$ 59-5-10 (Law. Co-op. 1976), and the governor appoints members to the State Commission on Higher Education on the recommendation of legislative delegations, S.C. CODE ANN. \$ 59103-10 (Law. Co-op. 1976 \& Supp. 1991).

120. See, e.g., S.C. CODE ANN. \$ 59-17-20, \2(a) (Law. Co-op. 1976). In Alabama, delegation approval is necessary to put the question of the merger of city and county school systems before the voters for a referendum, as well as to authorize a referendum on increasing the number of county schools. Marshall County May Consolidate Schools, UPI, Sept. 21, 1987, available in LEXIS, Nexis Library, UPI File.

121. In some South Carolina counties, the legislative delegation has sole control over school finances and taxes. UNDERWOOD, supra note 20 , at 247. See also Computers and Technology in the Schools, S.C. BUs. J., Jan. 1, 1989, available in LEXIS, Nexis Library, Omni File (describing delegations as school funding source); State Developments, BNA DAILY REP. FOR EXECUTIVES, Dec. 18, 1987, available in LEXIS, Nexis Library, Omni File (thirty-nine school districts must seek financial relief from county councils or legislative delegations). In such counties, disagreement among delegation members can block passage of the school budget. See UPI, Sept. 13, 1983, available in LEXIS, Nexis Library, UPI File (untitled); UPI, Sept. 3, 1983, available in LEXIS, Nexis Library, UPI File (untitled). In some instances, city school districts must seek similar relief from delegations. See, e.g., ALA. CoNST. amend. 456 (1990) (addressing city school taxes). 
legislative process. ${ }^{122}$ Delegations lobby for general legislation having statewide application but local interest-such as amendments to the state constitution that would permit delegations to pass legislation authorizing special tax districts ${ }^{123}$ or counties to implement special sales taxes. ${ }^{124}$

Although there is some resemblance between local delegations and state delegations in the United States House of Representatives, local delegations possess significantly more formal decisionmaking authority. ${ }^{125}$ State congressional delegations are informal caucuses whose members are those representatives elected from the congressional districts in each state. ${ }^{126}$ These delegations often meet at regular intervals to discuss pending or proposed legislation, ${ }^{127}$ but are not granted autonomy by Congress. ${ }^{128}$

\section{Procedures for Passing Local Legislation}

Local legislation follows a winding path through state legislatures, and the respective roles of delegations and the legislature as a whole are carefully delineated. In exercising the functions described above, delegations follow one set of procedures while the state legislature, in turn, employs another. In some states the procedures are highly formalized; in others, they more closely resemble customs or practices than rules of law. ${ }^{129}$ In both types of systems,

122. For a discussion of the role that interest groups play in the legislative process, see Keith $\mathrm{E}$. Hamm, Legislative Committees, Executive Agencies and Interest Groups, in HANDBOOK, supra note 20, at 573.

123. These Businesses Tax Themselves, supra note 116, at 17 (Georgia).

124. Craig A. Aronoff, Private Firms to Spend Millions Bringing Bus Service to Cobb, ATLANTA BUS. CHRON., May 26, 1986, \$2, at 2B.

125. State delegations play a less important role in the United States Senate, although they have a limited role in making certain federal appointments. By custom, the Senators of the majority party approve United States Attomeys and candidates for federal judgeships in their states. See, e.g., LAWRENCE BAUM, AMERICAN COURTS: PROCESS AND POLICY 111-13 (1986) (senatorial courtesy for federal judgeships).

126. State delegations differs in composition from county delegations in another significant respect. Because congressional districts do not cross state lines, state delegations do not include members from different states. 2 U.S.C. $\$ \S 2 a, 2 c$ (1988); David R. Mayhew, Congressional Representation: Theory and Practice in Drawing the Districts, in REAPPORTIONMENT IN THE 1970's, at 249, 252-53 (Nelson W. Polsby ed., 1971). The significance of this distinction for county delegations is discussed infra notes 298-99 and accompanying text.

127. See RANDALl B. RIPLEY, PARTY LEADERS N THE HOUSE OF REPRESENTATIVES 169-175 (1967).

128. Nevertheless, membership in a state delegation can be a source of voting cues once legislation reaches the floor. See, e.g., Barbara Deckard, State Party Delegations in the United States House of Representatives-An Analysis of Group Action, 5 POLTTY 311 (1973); Barbara Deckard, State Party Delegations in the United States House of Representatives-A Comparative Study of Group Cohesion, 34 J. POL. 199 (1972). In addition, committee assignments are often made on the basis of membership in a particular delegation. Charles J. Bullock, III, The Influence of State Party Delegations on House Committee Assignments, 15 MDWEST J. POL. SCI. 525 (1971); Nicholas A. Masters, Committee Assignments in the House of Representatives, 55 AM. POL. SCI. REV. 345-357 (1961). For case studies of state delegations in the United States House of Representatives, see Alan Fiellin, The Functions of Informal Groups in Legislative Institutions: A Case Study, 24 J. POL. 72 (1962); John H. Kessel, The Washington Congressional Delegation, 8 MIDWEST J. POL. SCI. 1 (1964).

129. Compare GA. H. REP. R. 11 (describing delegation decision rules) and N.C. H. REP. R. 27 (establishing local legislation committees) with CROWELL, supra note 23, at 39 (describing legislative courtesy as custom). 
however, the state legislature gives delegations virtual plenary control over local legislation. It is this autonomy that raises the question of whether the composition of delegations can be cognizable under the Voting Rights Act. ${ }^{130}$

Although there is no uniform legislative process for considering local legislation, many aspects of the process are similar across states. ${ }^{131}$ At the beginning of every legislative session, the local delegation meets to discuss the legislation its members will introduce that year. Legislative proposals are received from a wide variety of sources-individuals, city or county governing bodies, political groups, and other constituencies - and approved or rejected by the delegation. ${ }^{132}$ Before proposed legislation can be introduced, it must be advertised in the local newspaper within certain specified time periods. ${ }^{133}$ After advertisement, the delegation member who "authored" the bill formally introduces it in the legislature. The bill is then referred to the committee that has jurisdiction over local legislation ${ }^{134}$ and, if approved by that body, is subsequently placed on the calendar for floor consideration. The bill is read the requisite number of times before the legislature votes on it, and is passed once it reaches the floor if a majority of voting legislators approve it. The bill is then introduced in the other house of the legislature, in which similar procedures are followed. The local legislation becomes law once the governor signs it.

This description of how local bills are enacted resembles the standard textbook account of the legislative process. ${ }^{135}$ However, legislative norms, particularly the tradition that the delegation is the locus of all decisionmaking of local import, distinguish the process employed in considering local bills from the process for considering general legislation. ${ }^{136}$ This powerful norm is re-

130. See infra notes $267-69$ and accompanying text.

131. MALCOLM E. JEWELl, REPRESENTATION IN STATE Legislatures 7 (1982). The citations to legislative procedures in this Section do not purport to be exhaustive, but are instead intended to describe a model with characteristics common to many states. The internal rules and handbooks of particular legislatures are the most useful source of information about specific state procedures. See, e.g., CROWELL, supra note 23; JACKSON AND STAKES, supra note 23; THE LEGISLATIVE PROCESS: A HANDBOOK FOR AlABAMA LegiSlators (Robert L. McCurley, Jr. ed., 4th ed. 1987) [hereinafter AlaBAMa HaNDBOoK].

132. For a discussion of the interactions between delegations, constituents, and other interest groups, see JEWELL, supra note 131 , at $56,136$.

133. Typically, this requirement is mandated by state law. See, e.g., GA. CoNsT. art. 3, § 5, § 9. Notice of intent to introduce the local act must be published in the local newspaper in the section where other legal notices are printed, and an affidavit or copy of the published notice must accompany the bill when it is introduced. See, e.g., JACKSON \& STAKES, supra note 23, at 89 . State courts have strictly construed these requirements and have invalidated local acts where the requirements were not satisfied. See, e.g., Smith v. City Council of Augusta, 47 S.E.2d 582 (Ga. 1948); Smith v. McMichael, 45 S.E.2d 431 (Ga. 1947).

134. In some states, a single committee in each legislative house considers all local legislation without regard to substance, see, e.g., JACKSON \& STAKES, supra note 23, at 132, 134 (describing Georgia General Assembly); S.C. SEN. R. 19. In others, several committees share the workload, see, e.g., CRowEL, supra note 23, at 39 n.3 (describing North Carolina); ALABAMA HANDBOOK, supra note 131, at 65.

135. For a general description of the procedures whereby state legislatures consider legislation, see Malcolm E. Jewell \& SAMUEl C. PATterson, THE Legislative PROCESS IN THE UNITEd STATES (4th ed. 1986).

136. Norms are "informal rules, frequently unspoken because they need not be spoken, which may govem more effectively than any written rule. They prescribe "how things are done around here." BARBARA HINCKLEY, STABILITY AND CHANGE IN CONGRESS 59 (2d ed. 1978). The tradition of legislative deference 
ferred to by the catch-all phrase "local courtesy,"137 which essentially means that the legislature's involvement in considering local legislation as an institution-from introduction to passage-is merely pro forma. ${ }^{138}$ In the deliberative process, the stage at which the delegation votes on the legislation is critical. ${ }^{139}$ The committee responsible for local bills will only approve legislation supported by the requisite number of members of the legislative delegation. ${ }^{140}$ Committees typically play a very minor role in considering local legislation, simply reporting out of committee all legislation that has the backing of the relevant delegation. ${ }^{141}$ Upon reaching the floor, legislation approved by a delegation is almost always enacted, while conversely, legislation lacking the approval of the delegation is rarely-if ever-approved. Local courtesy is reinforced by other legislative procedures that limit the consideration local legislation receives from the legislature as a whole. ${ }^{142}$

to delegation decisions has the status of an informal rule. See Kousser, How to Determine Intent, supra note 94, at 714 (distinguishing formal and informal rules).

137. JACKSON \& STAKES, supra note 23, at 89 . Another term that is sometimes used is "legislative courtesy." See CROWELL, supra note 23 , at 39 ; THOMAS \& STEWART, supra note 23, at 149. Although the local courtesy rule originated many years ago, its use today continues unabated.

138. The practice of legislative deference to delegations is identified in accounts describing state legislatures, see, e.g., JACKSON \& STAKES, supra note 23, at 89; THOMAS \& STEWART, supra note 23, at 149-50, and by courts in the context of deciding Voting Rights Act claims, see, e.g., Rogers v. Lodge, 458 U.S. 613,626 (1982) (noting that "legislature defers to [delegation's] wishes on matters of purely local application"); City of Mobile v. Bolden, 446 U.S. 55, $74 \mathrm{n.21}$ (1980); McMillan v. Escambia County, 638 F.20 1239, 1246 n.14 (5th Cir. Feb. 1981), Hardy v. Wallace, 603 F. Supp. 174, 176 (N.D. Ala. 1985), Buskey v. Oliver, 565 F. Supp. 1473, 1477 (M.D. Ala. 1983) (approval by delegation "unwritten prerequisite" to passage by legislature). See also The Other Side of Edwards' Case for a Casino, TMMES PICAYUNE (New Orleans), Aug. 23, 1992, at B6 (letter of State Rep. Mitch Landrieu) ("The longstanding and well-respected tradition in the legislature is to honor the wishes of a local delegation on issues of major importance."). The local courtesy rule is supported by the rationale that matters of purely local concern should be decided by representatives of those citizens most affected by the legislation. When a legislative delegation agrees on the need for a legislative enactment that affects only its locality, other members of the legislature defer to its judgment. Members of the legislature expect that the same consideration will in turn be extended to legislation that affects their localities. See JACKSON \& STAKES, supra note 23, at 89-90; JEWELL, supra note 131, at 7, 131; LOCKARD, supra note 35, at 118 .

139. In City of Mobile v. Bolden, the Court noted that delegation's opposition to a local bill will prevent it from reaching the floor for debate. 446 U.S. $55,74 \mathrm{n} .21$ (1980). Other decisions do not identify the point in the legislative process at which the delegation's support or opposition is decisive. See, e.g., McMillan, 638 F.2d 1239; Buskey, 565 F. Supp. at 1477.

140. See generally Local Bill Policies and Procedures Manual, supra note 23.

141. See S.C. SEN. R. 19 (establishing role of committee with jurisdiction over local legislation as relatively inactive).

142. Local legislation receives fewer legislative readings, is considered on an expedited basis, and is often placed on a separate calendar. Local legislation in Georgia, for example, is read once before a floor vote is taken whereas general legislation is read three times. JACKSON \& STAKES, supra note 23, at 89, 130. These readings are constitutionally mandated. GA. CONST. art. 3, § 5, \ 8 (local legislation); GA. CoNST. art 3, $\$ 5$, I 7 (general legislation). Uncontested local legislation is placed on a separate local bill calendar and is voted upon as a package. JACKSON \& STAKES, supra note 23, at 89. Legislative rules for South Carolina also establish separate calendars for local legislation, S.C. SEN. R. 33; S.C. H. REP. R. 6.3 (7), (11A) \& (13A), and set strict time limits for its consideration. S.C. H. REP. R. 6.3(14)(e). 
The Supreme Court's opinion in City of Mobile v. Bolden ${ }^{143}$ provides the most comprehensive discussion of the local courtesy rule in a case decided under the Voting Rights Act. In Bolden, a plurality of the Court established a subjective intent standard for vote dilution claims under the Constitution and section 2 of the Voting Rights Act. ${ }^{144}$ In discussing the relevance of evidence suggesting discriminatory intent, the Court acknowledged that local courtesy was the prevailing practice by defining the intent of Mobile's legislative delegation as the critical factual inquiry in the case. ${ }^{145}$ The Court noted that several proposals to alter Mobile's form of government had been defeated in the state legislature, where the senators and representatives constituting the Mobile delegation exercised effective veto power over local bills while "[u]nanimous approval of a local measure by the city delegation, on the other hand, virtually assures passage." 146 The Court emphasized that the motivations of these state legislators, rather than those of city officials, were relevant to whether Mobile's form of government had been maintained with the intent to discriminate against black voters. ${ }^{147}$

Another correlative aspect of the local courtesy rule involves the conventions governing the number of delegation members who must agree for local legislation to be approved. The unanimity requirement in force until the 1960's has been replaced by a majority rule in most instances. ${ }^{148}$ For legislation to be adopted, some majority of delegation members-ranging from a simple

143. 446 U.S. 55 (1980). The Supreme Court also addressed local courtesy in Rogers v. Lodge, where it upheld the district court's determination that the at-large system for electing the county commission in Burke County, Georgia had been maintained by the legislative delegation for the purpose of diluting black voting strength. 458 U.S. $613,621-27$ (1982).

144. A majority of the Court could not agree on the legal standard for proving racial purpose, and there were six separate opinions. See infra notes $145-47$ and accompanying text.

145. 446 U.S. at $74 \& \mathrm{nn}$. 20,21 . The dissenters also emphasized the role of the legislative delegation. Id. at 99 (White, J., dissenting) (in considering redistricting bills for the city commission, "a major concern [of county delegation members] has centered around how many, if any, blacks would be elected" (quoting Bolden v. City of Mobile, 423 F. Supp. 384, 397 (S.D. Ala. 1976)); id. at 139 (Marshall, J., dissenting) (explaining relevance of legislative delegation's actions or inaction). Voting rights historians also concur that the intent of local legislators, rather than the state legislature, is the appropriate focus when local courtesy is in force. See Kousser, How to Determine Intent, supra note 94, at 714; McCrary \& Hebert, supra note 89 , at 113 .

146. Bolden, 446 U.S. at 74 n.21.

147. The plurality, however, held that the plaintiffs had not established the requisite discriminatory intent, $i d$. at 65 , and reversed and remanded the case to the district court to determine whether Mobile's election system purposefully discriminated against blacks. On remand, the district court found that the atlarge system had been adopted and maintained for racial reasons. Bolden v. City of Mobile, 542 F. Supp. 1050,1068 (S.D. Ala. 1982). In describing the modifications that the delegation adopted in 1965, the court observed that these changes took place "during th[e] period that the bus boycott occurred in Montgomery, the police dogs and fire hoses were used in Birmingham against blacks, a black church was bombed in Birmingham resulting in the death of blacks, and the Selma to Montgomery march took place. Anything to increase black representation just would not fly." $I d$.

148. It is possible that this switch occured because black candidates were running for elected office. A "diverse" delegation could no longer operate under the "gentlemen's agreements" that pervaded early delegation rule. See Kovach, supra note 81 , at 31 . Because delegations have been the subject of virtually no scholarly study, no firm conclusions can be reached. 
majority (one-half plus one) to a supermajority-must agree to the bill. ${ }^{149}$ In some jurisdictions, these rules of decisionmaking are determined by the legislature as a whole, and the degree of consensus required for delegation approval is mandated by statute, legislative rule, or legislative custom. ${ }^{150}$ In other cases, delegations are permitted to establish their own decision criteria. ${ }^{151}$

Despite some variation in these rules, the local courtesy norm is consistent. The success of local bills depends almost entirely upon the approval of the appropriate county delegation. In this sense, the delegation exercises nearly complete autonomy in considering local legislation.

\section{The Richmond County, Georgia Delegation}

A case study ${ }^{152}$ of the deliberations of Richmond County, Georgia's delegation illustrates the range of powers exercised by legislative delegations and the procedures they follow. Richmond County is located in central east Georgia. In 1983, eight state legislators sat on the Richmond County legislative delegation. Six were elected to the Georgia House of Representatives, while two were

149. Under supermajority voting rules, a decision is not approved unless, at a minimum, one more vote is obtained than that necessary for a simple majority. Karlan, supra note 2, at 11 n.35; Edward P. Schwartz \& Warren F. Schwartz, Decisionmaking by Juries Under Unanimity and Supermajority Voting Rules, 80 GEO. L. J. 775 (1992). For cases discussing the various decision rules applicable to delegation deliberations, see City of Mobile v. Bolden, 446 U.S. 55, $74 \mathrm{n.21}$ (1980) (two-thirds of senate delegation and majority of house delegation in Mobile, Alabama); Buskey v. Oliver, 565 F. Supp. 1473, 1477 (M.D. Ala. 1983) (four-fifths of Montgomery, Alabama delegation). See also S.C. CoDE ANN. § 59-15-10 (Law. Co-op. 1976) (senate member and at least one-half of house members for appointment of county school boards); GA. SEN. R. 187 (majority, with special provision if senators evenly divided); GA. H. REP. R. 11 (unanimous, unless delegation adopts its own rules). Moreover, these rules are not static but can change during each legislative session. See infra notes $472-78,489-95$ and accompanying text for the potential for discrimination in such changes.

150. See generally 50 STATES, supra note 22 .

151. See GA. H. REP. R. 11 (establishing unanimity rule but allowing delegations to adopt their own decision rules); CrowELL, supra note 23, at 39 (describing variation in delegation decision rules in North Carolina). Of the 159 county delegations in the Georgia House of Representatives, U.S. DEPT. OF COMMERCE, COUNTY AND CITY DATA BOOK 1988 (1988) (Appendix B-1) (listing number of counties in Georgia), 16 adopted their own rules for the 1991 legislative session. Of these, 3 adopted supermajority decision rules (copies of decision rules on file with author).

152. This case study is based on my experiences as an attorney in the Voting Section of the Civil Rights Division, United States Department of Justice. I represented the United States in a lawsuit challenging the method of election for the Augusta city council. United States v. City of Augusta, No. CV 187-004 (S.D. Ga. consent judgment filed July 22, 1988) (on file with author). The Augusta litigation is discussed in Frank R. Parker, Voting Rights Enforcement in the Reagan Administration, in ONE NATION INDIVISIBLE: THE CIVL RIGHTS CHALLENGE FOR THE 1990s 381 (Reginald C. Govan \& William L. Taylor eds., 1989) (report of the Citizens' Commission on Civil Rights). Augusta is the Richmond County seat and the fourth largest city in Georgia. Through this case study, I seek to emphasize the importance of the day-to-day activities of legislative delegations. Although my account is neither a narrative nor a story, I borrow from both techniques. Scholars in a number of fields have utilized narrative and storytelling. See, e.g., DERRICK BELL, AND WE ARE NOT SAVED (1987) (critical race theory); JAMES MCPHERSON, BATTLE CRY OF FREEDOM: THE CIVIL WAR ERA ix-x (1988) (historiography); PATRICIA WILLIAMS, THE ALCHEMY OF RACE AND RIGHTS (1991) (critical literary and legal theory); Kathryn Abrams, Hearing the Call of Stories, 79 CAL. L. REV. 971 (1991) (feminist legal scholarship); Richard Delgado, Campus Antiracism Rules: Constitutional Narratives in Collision, 85 Nw. U. L. REV. 343 (1991); Lucie E. White, Subordination, Rhetorical Survival Skills, and Sunday Shoes: Notes on the Hearing of Mrs. G., 38 BUFF. L. REV. 1 (1990) (lawyering). 
elected to the Georgia Senate. The delegation included two black members (Representatives Charles Walker and George Brown) and six white members (Representatives Travis Barnes, Donald Cheeks, A. Jack Connell, and Michael Padgett, and Senators Jimmy Lester and Majority Leader Thomas Allgood). ${ }^{153}$ The same individuals served on the legislative delegation for the city of Augusta, with the exception of Representatives Barnes and Padgett, whose districts did not include any portion of the city. ${ }^{154}$ The city's house delegation thus had two white members and two black members.

The Richmond County delegation had broad power over local legislation and enjoyed a high degree of autonomy in the state legislature. ${ }^{155}$ The city and the county delegations followed the same procedures for passing local legislation. The signatures of a majority of the house delegation were required for passage of local bills. Following approval by the house delegation, a bill was enacted by the house; it then required the signature of both senators before it would be enacted by the senate. Once the bill passed both sections of the delegation in this manner, it was enacted by the legislature and signed by the governor. The last two steps were usually mere formalities because local legislation was almost always enacted in Georgia once it had delegation support.

Augusta blacks outnumbered whites for the first time after the 1980 census count. ${ }^{156}$ In order to negate black voting power, Richmond County's legislative delegation addressed the question of whether to eliminate the City of Augusta by consolidating it with Richmond County, or instead to enlarge the city by annexing adjoining suburbs. In a 1981 runoff election, the city elected

153. Chris Peacock, Black Leaders Push for Renewed Action, AugusTA CHRON., July 24, 1983, at 1B, 2B (describing racial composition of delegation); John H. Sorrells, Jr., Allgood Unveils Consolidation Bill; Existing Services Left Untouched, AUGUSTA CHRON., Jan. 21, 1983, at 1A, 2A (listing delegation members). In 1984, two members of the delegation changed but the racial composition of the delegation remained the same. Representative Barnes was replaced by Dick Ransom and Senator Lester was replaced by Frank Albert. Margaret Twiggs, DeVaney to Present City's Needs Tomorrow, AuguSTA CHRON., Nov. 18, 1984, at 3B.

154. John S. Sorrells, Jr., House Approves Bill Halving City Council, Requiring Ward Vote, AugusTA CHRON., Feb. 12, 1983, at 1A. Controversy later arose when the city annexed portions of both districts, making the districts' representatives eligible to vote on city matters. See infra notes 174-83 and accompanying text.

155. For a more detailed account of the interaction between legislative delegations and state legislatures, see supra notes 130-52 and accompanying text.

156. COUNTY AND CITY DATA BOOK, supra note 151, at 634 (blacks $53.5 \%$ of Augusta's population). Whites, however, retained a majority of voting age residents. BUREAU OF THE CENSUS, U.S. DEP'T OF COMMERCE, Series PC80-1-B 12, 1980 CENSUS OF POPULATION, GENERAL POPULATION CHARACTERISTICS: GEORGIA, at 53 (Table 25) (1980) [hereinafter 1980 CENSUS OF POPULATION]. According to the 1990 census, blacks currently comprise 56\% of Augusta's total population, BUREAU OF THE CENSUS, U.S. DEP'T OF COMMERCE, Series 1990 CPH-1-12, 1990 CENSUS OF POPULATION AND HOUSING, SUMMARY POPULATION AND HOUSING CHARACTERISTICS: GEORGIA, 53 (Table 3) (1990) [hereinafter 1990 CENSUS OF POPULATION AND HousING], and 50.7\% of its voting-age population. Bureau of the Census, U.S. Dep't of Commerce, General Population Charactertistics, at Table 61 (unpublished census table, on file with author) (Age and Sex by Race and Hispanic Origin: 1990). 
Edward McIntyre as its first black mayor. ${ }^{157}$ Following the election of Mayor McIntyre, white residents pushed to consolidate Augusta with the remainder of unincorporated Richmond County. This consolidation, designed to avert black control of city government, would abolish the city as an independent legal entity and replace it with a new solidly white political subdivision. ${ }^{158}$

In 1983, Senator Allgood and Representative Connell proposed consolidation legislation to the delegation. ${ }^{159}$ Black leaders swiftly opposed the consolidation plan because it would have made whites a strong majority in the new metropolitan government. ${ }^{160}$ Mallory Millender, editor and publisher of the local black newspaper, attacked the consolidation plan as "an effort to keep black people "where we belong' . . . impotent and out of politics." 161 Representative Walker, one of the two black members of the delegation, then introduced a competing bill which preserved the city as a legal entity, and which would have substituted ward voting for at-large voting and reduced the number of councilmembers from sixteen to eight. ${ }^{162}$ Ward voting would likely have led to black control of four of the eight seats on the newly-constituted city council, ${ }^{163}$ thereby effectively ending the veto power white voters held because of their slim voting majority in the city.

The Walker bill needed the support of three of the four house members eligible to vote on city matters, as well as the approval of both senators, in

157. Rick Rountree, McIntyre Wins Mayoral Runoff; First Black Voted Mayor of Augusta, AUGusTA CHRON., Oct. 29, 1981, at $1 \mathrm{~A}$. In the runoff election, $100 \%$ of the city's black residents voted for Mr. McIntyre, while 87\% of white voters supported his opponent. Deposition of Allan J. Lichtman, United States v. Augusta, No. CV 187-004 (S.D. Ga. Aug. 17, 1987) (Table 1, Racial Bloc Voting in Augusta, Ga., Black v. White Contests, Ecological Regression Estimates, 1979-1986). In the election that led to the runoff, even fewer whites supported Mr. McIntyre, with $94 \%$ of white voters casting a ballot for his white opponent. ld.

158. Blacks comprised a significantly smaller percentage of the population in the county as a whole, making up only $37.4 \%$ of county residents. 1980 CENSUS OF POPULATION, supra note 156, at 13 (Table 14). Consolidation is often viewed as a means of reducing minority political power. See, e.g., Donald G. Hagman, Introduction and Summary, 54 U. DET. J. URB. L. 681, 683 (1977) ("[M]inority leaders oppose consolidation because they view it as a move by the white community to retain political control."); Lawrence B. Garcia, Consolidation: The Racial Implications, 54 U. DET. J. URB. L. 717, 717 (1977) (discussing ethnic trends and minority control of cities).

159. John H. Sorrells, Jr., Bill Introduced to Merge Augusta, Richmond County, AugusTa CHRON., Feb. 9, 1983, at 1A, 2A. The bill also would have created a nine-member governing body, with each elected from individual districts and one of the members chosen as mayor-chairman. Id.

160. See id. at IA (unification legislation criticized for diluting black political strength). Although three of the nine seats were from majority-black districts, blacks opposed consolidation because it ensured that whites would elect a majority of councilmembers. J.S. Wright, Notes Ministers Against Unification, AUGUSTA CHRON., Feb. 21, 1983, at 4A (letter to editor from Reverend J.S. Wright, chairman of political action committee of Black Ministers Moming and Evening Conferences). Absent consolidation, the possibility that black voters might outnumber white voters in the city loomed on the horizon.

161. Marjorie Mayfield, Blacks' Role in Unification Sparks Debate, AUGUSTA CHRON., Feb. 4, 1983, at 18 .

162. Sorrells, House Approves Bill, supra note 154, at 1B.

163. John H. Sorrells, Lester Signs Merger Bill; Senate Passage Assured, Augusta CHRON., Jan. 25, 1983, at IA; Richmond Legislators to Discuss Local Bills They Plan to Introduce, AUGUSTA CHRON., Jan. 18,1983 , at $2 \mathrm{~B}$. In contrast to at-large voting, ward (or district) voting typically enhances the ability of minority voters to elect the representatives of their choice. 
order to pass. Though three of the four representatives signed the bill, ${ }^{164}$ the fourth, Representative Connell, who was white, invoked a "seldom-used" procedure to request that the bill be voted on separately so that his opposition could be recorded. ${ }^{165}$ Senator Allgood then employed another parliamentary tactic to eliminate the Walker bill and to substitute his consolidation bill in its place. ${ }^{166}$ This maneuver killed the ward voting proposal, even though neither the substitute bill nor any of the ensuing compromises gained delegation support. ${ }^{167}$

In 1984, the same conflict reemerged within the legislative delegation. In October of that year, Representative Walker proposed a new ward voting package linked to annexation. He stated that the role of blacks must be expanded to allow participation in the "social and political, as well as the economic side"" of life in Augusta. ${ }^{168}$ The proposed annexation would increase the population of Augusta from approximately 47,000 to at least 106,000 , while retaining approximately the same black-white ratio. ${ }^{169}$ The second portion of the package implemented ward voting for the city council. In response, Senator Allgood reiterated his support for total consolidation. ${ }^{170}$

In the 1985 legislative session that followed, Senator Allgood engineered a change in the senate rules to allow a full senate vote on disputed local legislation. ${ }^{171}$ This change also replaced the rule requiring both Richmond County senators to agree on a local bill before it passed (the unanimity rule) with a rule requiring only one senator to sign the bill. By altering the forum for considering local legislation, Senator Allgood, as the senate majority leader, could use his influence to circumvent the other local senator and exercise more

164. Sorrells, House Approves Bill, supra note 154, at 1B. The bill was signed by representatives Brown, Cheeks, and Walker.

165. Id. If a bill passed the delegation, the members who had not signed it rarely voiced opposition during floor consideration.

166. John H. Sorrells, Jr., Unification Plan Substituted for Bill, AUGUSTA CHRON., Feb. 19, 1983. Senator Allgood's move circumvented the normal procedure through which local legislation is first introduced in the house.

167. Chris Peacock, Legislators Plan Meetings Over Summer, Augusta CHRON., May 26, 1985, at 1B. In decrying the related proposal to implement ward voting for the county commission, the local newspaper opined: "The Richmond County legislative delegation should resist the siren calls of the Walker bill, knowing that the best solution for Black representation on the County Comm[i]ssion is for the best qualified black citizens to offer for election." Nix District Voting, AUGUSTA CHRON., Feb. 9, 1984, at 4A (editorial). Voting rights activists understand the term "well-qualified" black candidate to be a euphemism for a candidate who can appeal to white voters. See James U. Blacksher \& Larry T. Menefee, From Reynolds v. Sims to City of Mobile v. Bolden: Have the White Suburbs Commandeered the Fifteenth Amendement?, 34 HASTINGS L.J. 1, 37 n.255 (1982) (describing white efforts to "put in office the 'best' citizens from all-white business and professional classes").

168. Chris Peacock, Proposal to Double Augusta Population, Augusta CHron,, Oct. 9, 1984, at 1B (quoting Walker).

169. Id.

170. Chris Peacock, Views Vary on Proposal by Walker, AugusTA CHRON., Oct. 21, 1984, at IB.

171. Joan Kirchner, Legislature: Freeways and Funding Grab Annexation's Glory in '86, AUGUSTA CHRON., Jan. 5, 1986, at 1A; Chris Peacock, Forcible Annexation Won't Pass, Albert Says, AugusTA CHRON., May 17, 1985, at 2B. 
power over the local legislative agenda. ${ }^{172}$ Nonetheless, despite Senator Allgood's influence, the delegation remained deadlocked and neither the annexation nor the consolidation proposal made headway during the 1985 session. ${ }^{173}$

As a result of the deadlock within the delegation, the city organized a petition drive to annex the territory. ${ }^{174}$ In 1985 , Charles DeVaney, the newly elected white mayor of Augusta, ${ }^{175}$ presented an annexation plan to the city council. The resolution passed a racially divided city council despite charges that the annexations were racially selective. ${ }^{176}$

The city adopted ordinances implementing the plan in November of 1985. ${ }^{177}$ Two of these annexations added two additional house districts to the city's boundaries, house district 86 and house district $90 ;{ }^{178}$ the districts added two white members to the city delegation, Representatives Michael Padgett and Dick Ransome. ${ }^{179}$ The majority of territory in both legislators' districts re-

172. Peacock, supra note 171, at $2 \mathrm{~B}$; Peacock, supra note 167 , at $1 \mathrm{~B}$ (noting Allgood's "veto power over local bills").

173. Peacock, supra note 167, at 1B. Despite meetings called by Senator Allgood over the summer recess to break the deadlock on consolidation and annexation, the delegation remained splintered. Chris Peacock, Delegation Airs Disputes, AUguSTA ChroN., July 23, 1985, at 1B.

174. Don Rhodes, Augusta Annexation Efforts Die in Legislative Debate, Augusta CHRoN., Dec. 29, 1985, at 1A [hereinafter Rhodes, Annexation Efforts Die]. "Petition" is an alternative method by which Georgia cities may annex territory. The petitions must contain signatures of at least $60 \%$ of the property owners in the area to be annexed. See Don Rhodes, Committee Backs Annexation Plan, AUGUSTA CHRON., Aug. 16, 1985, at 1A. Typically, the petition method is more costly and cumbersome than the legislative method. Note, The Right to Vote in Municipal Annexations, 88 HARV. L. REV. 1571, 1607 n.193 (1975). In Augusta, the petition drive had a better chance of success than did the legislative proposals because of strife within the local delegation.

175. In 1984, Mayor McIntyre was convicted of extortion and sentenced to a five-year prison term. Ex-Mayor of Augusta Sentenced in Kickbacks, N.Y. TMES, July 10, 1984, at A12. Many members of the black community were outraged by the conviction. Mayor of Augusta Weighs Resignation After Guilty Verdict, N.Y. TMIES, May 1, 1984, at A23. Some believed that the mayor had been set up by powerful interests. Chris Peacock, McIntyre Supporters Rally, Raise Funds, AUGUSTA CHRON., Dec. 30, 1983, at 1B (black elected officials "charged law enforcement officials with a new type of racism"); Mike Vogel, Black Leaders Back McIntyre Despite Arrest, AUGUSTA CHRON., Dec. 25, 1983, at 1B (community had "doubts about the fairness of the investigation"). During the past decade, it has been widely alleged that a number of black politicians have been targeted for racially selective investigation and prosecution. See Mark Curriden, Selective Prosecution: Are Black Officials Investigative Targets?, 78 A.B.A. J. 54 (Feb. 1992).

176. Minutes of the Augusta City Council, Aug. 19, 1985, at $347-49$ (on file with author). All of the white members voted in favor of the annexations while three of the four black members voted against them. Id. at 350-51. See Don Rhodes, Augusta Council Vote Brings 1,747 Acres into City Limits, AugusTA CHRON., Aug. 20, 1985, at 1A (black councilmembers I.E. Washington, William H. Mays, III, Kathleen Beasley, and Margaret Armstrong voted against plan, while all white members voted in favor of it).

177. Minutes of the Augusta City Council, Nov. 4, 1985, at 402-05 (on file with author); Chris Peacock, Annexation Adds Acreage and Augustans, AUGUSTA CHRON., Nov. 5, 1985, at 1B. Racial divisions remained intact, with black members continuing to oppose the annexations. Black leaders asserted that a portion of predominantly black Albion Acres was excluded because "the majority of white city government leaders were interested only in making the city more white." Rhodes, Annexation Efforts Die, supra note 174, at 1 A.

178. John Winters, Voting Mix-Up Leaves Reduction of Panel in Limbo, AUGUSTA HERALD, June 21, 1986, at $1 \mathrm{~A}$.

179. John Winters, City Can File Suit Or Ignore Bill, Attorney Says, AuguSTA HERALD, June 22, 1986, at IA; Winters, supra note 178, at IA. Later, when the delegation reduced the size of the city council over the city's objection, a local columnist commented that legislators' power ranks alongside "taxation without representation." Margaret Twiggs, Walker's Bill Targets City Council, AUGUSTA CHRON., Feb. 9, 1986, at 
mained outside of the city limits. ${ }^{180}$ After the annexations were precleared by the Justice Department, ${ }^{181}$ black leaders alleged that the purpose of the 86th district annexation was to make it more difficult for black members of the delegation to prevail in delegation deliberations. ${ }^{182}$ The delegation also adopted a formal rule permitting only those representatives whose districts included a portion of the city to vote on city legislation and requiring a majority vote for delegation approval of legislation. ${ }^{183}$

At the same time, efforts to achieve annexation through legislation continued. ${ }^{184}$ The delegation held a public meeting to gauge the reaction to Senator Allgood's latest annexation plan. At this heated meating, Christine Bagwell, a white county resident, bluntly assessed the city's motivation for expansion: "the niggers are going to take over Augusta and they have done it."185 In the weeks following the meeting, Senator Allgood and Representative Padgett declared the annexation initiative dead. ${ }^{186}$ Senator Allgood summed up the year with the comment, "I'm not proud of it (the failure to pass annexation legislation), and I'm not proud of our delegation."187

In four years, the delegation had profound disagreements concerning ward voting, annexation and consolidation. During that time, two white members had been added to a racially divided delegation. Delegation rules had been manipulated to promote legislation favored by white leaders, and legislative obstacles had been placed in the way of ward voting. The delegation repeatedly frustrated the desires of black voters in Richmond County.

The epilogue to the Augusta story is a mixed one. The city's efforts to annex portions of white Richmond County in the mid-1980's failed when the

3E. The columnist was apparently referring to the fact that state legislators whose districts included only a portion of the city could nonetheless determine the outcome of city legislation.

180. See Winters, supra note 178, at 1A (annexations of house districts 86 and 90 comprised 57 actes and 1800 acres, respectively).

181. Letter from William Bradford Reynolds, Assistant Attorney General, Civil Rights Division, United States Department of Justice, to Paul H. Dunbar, III, Augusta City Attomey, Feb. 4, 1986 (on file with author) (preclearing annexations); Letter from Paul H. Dunbar, III, Augusta City Attorney, to Gerald W. Jones, Chief, Voting Section, Civil Rights Division, United States Department of Justice, Dec. 5, 1985 (on file with author) (submitting annexations adopted on November 4, 1985).

182. My review of the Department of Justice's public file revealed no evidence suggesting that the impact of the annexations on the delegation was raised during section 5 review.

183. Winters, supra note 178 . Although the record is not entirely clear, it appears that the rule simply formalized the delegation's existing practice that only legislators whose districts included the city limits could vote on city legislation. See Richmond Legislators to Discuss Local Bills They Plan to Introduce, AUGUSTA CHRON., Jan. 18, 1983, at 2B (delineating delegation members who may vote on ward voting proposal); see also Chris Peacock, Views Vary on Proposal by Walker, AUgUSTA CHRON., Oct. 21, 1984, at $1 \mathrm{~B}$ (discussing voting eligibility for matters affecting specific portions of county).

184. See Peacock, supra note 177 , at $1 \mathrm{~B}$.

185. Chris Peacock, Flared Tempers Mark Annexation Discussion, AUGUSTA CHRON., Oct. 18, 1985 , at 1B. When Representative Cheeks accused Senator Allgood of "telling falsehoods," the Senator responded, "I'm going to ignore your remark because I think that's the only way we can have a delegation." Id. Delegation Chairman Padgett banged his gavel in vain during the heated exchange.

186. Chris Peacock, DeVaney, Walker Debate Annexation, AugusTA CHRON., Nov. 14, 1985, at 1A.

187. Rhodes, Annexation Efforts Die, supra note 174, at 1A. 
Justice Department deemed the city's annexation policy to be racially selective. ${ }^{188}$ In 1988, the city settled the section 2 lawsuit challenging its at-large method of election and implemented ward voting as a condition of the settlement. ${ }^{189}$ Not long afterward, the Richmond County delegation adopted consolidation legislation that would have eliminated the city as a legal entity and, simultaneously, wiped out the gains made through ward elections. ${ }^{190}$ After the population growth reflected in the 1990 census made the consolidated government's election districts unenforceable ${ }^{191}$ the delegation failed to agree on replacement consolidation legislation in 1992 and thus returned the city to its original status. ${ }^{192}$ During the same period, the delegation added a white member to its numbers by attaching a minuscule portion of unpopulated Richmond County to a district centered on neighboring counties. ${ }^{193}$

Now that a clear picture of the powers of delegations has emerged, a discussion of voting rights jurisprudence is necessary to provide context for the issue of how delegations fit within this framework.

\section{THEMES IN VOTING RIGHTS JURISPRUDENCE}

Voting rights doctrine provides a starting point for assessing discrimination in the structure of delegations. As currently articulated, the doctrine involves three stages of inquiry: the first (the "election procedures" phase) looks at preelection and election day activities; the second (the "vote dilution" stage) examines how election structures affect the composition of the electorate and

188. Letter from William Bradford Reynolds, Assistant Attomey General, Civil Rights Division, United States Department of Justice, to Charles DeVaney, Mayor, Augusta, Georgia 1 (July 27, 1987) (on file with author).

189. United States v. City of Augusta, No. 187-004 (S.D. Ga. consent judgment filed July 22, 1988). See also supra note 152 .

190. The Justice Department initially objected to the timing of the city's decision to hold a special election deciding the consolidation question. See Letter from William Bradford Reynolds, Assistant Attomey General, Civil Rights Division, United States Department of Justice, to Linda Beazley, Executive Director, Richmond County Board of Elections 1 (July 15, 1988) (on file with author). The city responded by agreeing to hold the referendum during the 1988 general election. After voters approved consolidation in the referendum, the United States Department of Justice objected to the consolidation plan. See Letter from James P. Tumer, Acting Assistant Attorney General, Civil Rights Division, United States Department of Justice, to Linda Beazley, Executive Director, Richmond County Board of Elections 4-5 (May 30, 1989) (on file with author). The city then sought preclearance of the consolidation plan in federal district court. City Council of Augusta v. United States, No. 90-0171 (D.D.C. Jan. 24, 1990).

191. Motion of Defendants-Intervenors to Dismiss for Mootness, Lack of Case or Controversy, and Failure to Prosecute, City Council of Augusta v. United States, No. 90-0171, at 1-2 and Exhibit A (Joint Status Report) at 3 (D.D.C. Feb. 11, 1992) (districts severely malapportioned).

192. Plaintiffs' Notice of Disposition of Consolidation Bill at 2, City Council of Augusta v. United States, No. 90-0171 (D.D.C. Apr. 8, 1992). After the legislature failed to enact new legislation, the federal district court dismissed the city's challenge as moot. Order, City Council of Augusta v. United States, No. 90-0171 (D.D.C. Aug. 24, 1992). Had local legislation been passed, the legislation would have been submitted for section 5 review, and the process would have begun anew.

193. For a discussion of the Richmond County delegation gerrymander and its resolution see infra notes 330-35 and accompanying text. For a general discussion of delegation gerrymanders, see infra Part III(A)(3). 
thus the ability of minority voters to elect candidates. ${ }^{194}$ Taken together, these two aspects of the doctrine address discrimination in the first level of political competition, beginning with pre-election day activities and ending with the election itself. ${ }^{195}$

A third approach, appearing in the last quarter century of voting rights jurisprudence, recognizes that election outcomes should not define the end of the inquiry into equality. This post-election stage considers the way in which electoral power is used in office after election day. ${ }^{196}$ Although the viability of post-election stage litigation has been eclipsed by the Presley decision, this approach remains important both as a critique of that decision and as an argument for amending the Voting Rights Act.

\section{A. Election Procedures: Formal Barriers to Participation}

Black voters have attacked formal barriers to participating in elections as violations of the Voting Rights Act as well as the Fourteenth and Fifteenth Amendments to the Constitution. ${ }^{197}$ Formal impediments to voting include absolute denials of the franchise, procedures making it more difficult actually to cast a vote, and rules affecting other pre-election activities. Cases decided

194. Although the term "vote dilution" is used with great frequency by commentators and the courts, no single definition is accepted in all contexts. Davidson, supra note 104, at 4. Most often the term is used to describe election laws and practices-such as at-large elections-that make it more difficult for minority groups to elect candidates to office without restricting the ability of minority voters to cast a ballot. Id. This definition may be too narrow in some contexts because it fails to acknowledge that any action that limits the practical political power of minority voters could properly be viewed as resulting in "vote dilution"-that is, making the votes of minority voters worth less than those of their white counterparts. See Frank R. Parker, The Mississippi Congressional Redistricting Case: A Case Study in Minority Vote Dilution, 28 How. L.J. 397, 397 (1985) (quoting a speech by Reverend Jesse Jackson comparing vote dilution to "yellow rain"). Nonetheless, in deference to common usage, I use the term "vote dilution" in this section in its narrower sense to refer to those mechanisms that determine the composition of the electorate voting for a given office.

195. Other commentators have traced similar themes in the development of voting rights jurisprudence, although they have labeled the relevant categories somewhat differently. See Davidson, supra note 104, at 3 (identifying relevant types of discrimination as disfranchisement, candidate diminution and vote dilution); Kathryn Abrams, "Raising Politics Up:" Minority Political Participation and Section 2 of the Voting Rights Act, 63 N.Y.U. L. REV. 449, 453 (1988) (identifying themes of political opportunity and electoral success); Guinier, supra note 29, at 1415-18; Lani Guinier, The Triumph of Tokenism: The Voting Rights Act and the Theory of Black Electoral Success, 89 MICH. L. REv. 1077, 1093-94 (1991) [hereinafter Guinier, Triumph of Tokenism] (describing first and second generation voting rights litigation).

196. See, e.g., Guinier, Triumph of Tokenism, supra note 195, at 1126 (describing prejudice in the postelection phase as a "third-generation" problem); Alan Howard \& Bruce Howard, The Dilemma of the Voting Rights Act-Recognizing the Emerging Political Equality Norm, 83 COLUM. L. REV. 1615, 1654 (1983) (criticizing remedies that provide a "bye" into the second level of political competition); Pamela S. Karlan, Maps and Misreadings: The Role of Geographic Compactness in Racial Vote Dilution Litigation, 24 HARV. C.R.-C.L. L. REv. 173, 237 (1989) (describing remedies to "enhance the practical political power and inclusion of minority representatives").

197. Most litigants making statutory challenges to direct impediments to voting rights have alleged violations of section 5. See infra notes 203-07 and accompanying text. The amendment of section 2 also has spawned litigation challenging such barriers. See, e.g., Operation Push v. Allain, 674 F. Supp. 1245 (N.D. Miss. 1987), aff d, 932 F.2d 400 (5th Cir. 1991) (applying section 2 to dual registration system and prohibition on satellite registration); Harris v. Graddick, 601 F. Supp. 70 (M.D. Ala. 1984); 615 F. Supp. 239 (M.D. Ala. 1985) (appointment of poll officials). 
under the Constitution involve challenges to the white primary, ${ }^{198}$ literacy tests, ${ }^{199}$ poll taxes, ${ }^{200}$ and manipulations of city boundaries. ${ }^{201}$ Although the Supreme Court was shamefully slow to recognize that these devices infringed upon protected voting rights, ${ }^{202}$ there is no doubt that the practices disfranchised blacks by making it more difficult for them to cast a ballot.

In recent years, section 5 of the Voting Rights Act has provided an effective weapon for striking down more subtle impediments to voting. ${ }^{203}$ When the Supreme Court first addressed the scope of section 5, in Allen v. State Board of Elections, ${ }^{204}$ the Court applied that section to changes in candidate qualifications, procedures for casting write-in votes, changes from elective to appointive offices, and changes from single-member districts to at-large elections. ${ }^{205}$ Later, the Court found that section 5 reached changes in the location of polling places ${ }^{206}$ and personnel rules governing leaves of absence for prospective candidates. ${ }^{207}$

The constitutional cases, coupled with the decisions under section 5, afford broad protections for voting rights in the pre-election and election day phase. The doctrine protects a broad span of political participation, ranging from

198. Terry v. Adams, 345 U.S. 461 (1953). See also Smith v. Allwright, 321 U.S. 649 (1944); Nixon v. Condon, 286 U.S. 73 (1932); Nixon v. Herndon, 273 U.S. 536 (1927). The white primary is described supra note 8.

199. In South Carolina v. Katzenbach, 383 U.S. 301, 333-34 (1966), the Court recognized that under Lassiter v. Northampton County Bd. of Elections, 360 U.S. 45, 53 (1959), literacy tests were not per se unconstitutional but could be applied in a discriminatory fashion. The cases holding literacy tests unconstitutional dealt with statutes that exempted certain groups from taking the test ("the grandfather clause cases"), see Guinn v. United States, 238 U.S. 347 (1915), and Myers v. Anderson, 238 U.S. 368 (1915), or imposed procedural hurdles to passing the test, see Lane v. Wilson, 307 U.S. 268 (1939) (finding cause of action under Fifteenth Amendment in suit against literacy requirements).

200. See Harper v. Virginia Bd. of Elections, 383 U.S. 663 (1966) (overruling Breedlove v. Suttles, 302 U.S. 277 (1937)) (Fourteenth Amendment).

201. See Gomillion v. Lightfoot, 364 U.S. 339 (1960). The Gomillion case is discussed in more detail supra note 11.

202. The Court's halfhearted efforts to enforce the Fifteenth Amendment prior to the enactment of the Voting Rights Act are well-documented. See, e.g., JOEL WILLIAMSON, THE CRUCIBLE OF RACE: BLACKWHITE RELATIONS IN THE AMERICAN SOUTH SINCE EMANCIPATION (1984); Emma C. Jordan, The Future of the Fifteenth Amendment, 28 How. L.J. 541 (1985). The Court's more recent efforts are no less troubling. See Emma C. Jordan, Taking Voting Rights Seriously: Rediscovering the Fifteenth Amendment, 64 NEB. L. REv. 389 (1985).

203. The Supreme Court upheld the constitutionality of section 5 in South Carolina v. Katzenbach, 383 U.S. 301 (1966). The Department of Justice, in its role as chief enforcer of section 5, reviews many changes that affect the pre-election and election-day activities of voters. Between 1965 and October 1991, the Department reviewed nearly 200,000 voting changes. United States Department of Justice, Civil Rights Division, Voting Section, Number of Changes by State and Calendar Year, 1965-1991 (Oct. 9, 1991) (on file with author). See infra notes $437-50$ for a description of the administrative and judicial mechanism for section 5 review.

204. 393 U.S. 544 (1969). The Court held that section 5 applies to any measure that could "undermine the effectiveness of voters," id. at 570-71, and should be given "the broadest possible scope," id. at 567 .

205. The method of election change is more properly considered a vote dilution device, rather than a formal barrier. See supra note 194 (defining vote dilution).

206. Perkins v. Matthews, 400 U.S. 379, 388 (1971) ("[Polling place] locations at distances remote from black communities or at places calculated to intimidate blacks from entering, or failure to publicize changes adequately" could affect voters' ability to exercise franchise.).

207. Dougherty County Bd. of Educ. v. White, 439 U.S. 32 (1978). 
election day activities to earlier points at which, for example, a restrictive personnel rule can discourage candidates from running for office. This "interactive" view of the political process looks backward from election day, encompassing the various steps along the way that make the election of candidates to office possible.

\section{B. Vote Dilution: The Electoral Phase}

In the wake of court decisions striking down formal restrictions on the right to vote, plaintiffs developed new theories to address other less obvious-but equally insidious - forms of voting discrimination. These approaches looked at existing electoral structures, under which minority candidates were consistently defeated, and asserted that the minority voters' votes were worth less - that is, their votes were diluted-when compared to those of white voters. ${ }^{208}$

The starting point for an examination of vote dilution litigation is Reynolds v. Sims. ${ }^{209}$ In that case, suburban residents of Alabama's large cities alleged their votes were worth less than those of rural voters because legislative districts containing vastly different numbers of people were given the same numbers of representatives. ${ }^{210}$ The Court, equating vote dilution with mathematical inequality, noted that legislative apportionments that were not population-based deprived voters in overpopulated districts of the right to vote no less than would policies that prohibited them from voting, permitted other voters to cast more votes, or multiplied the votes of others by some factor. ${ }^{211} \mathrm{~A}$ voter, the Court held, is deprived of the right to vote if the district in which he or she resides elects fewer representatives than a district with an equal or greater number of residents, or elects the same number of representatives as does a district with fewer residents. ${ }^{212}$

208. Vote dilution is defined supra note 194, but the line between direct impediments to voting and vote dilution mechanisms is not always so clear. For instance, although poll taxes are commonly categorized as formal barriers to participating in elections, see Davidson, supra note 104 , at 3 , others define poll taxes as vote dilutive, see BELL, supra note 152, at 89 . Even though annexations and deannexations are analogous to other voting restrictions in that they impose barriers to voting, they also might be considered vote dilutive because they operate as gerrymanders by determining the boundaries of voting districts. See Frank R. Parker, Racial Gerrymandering and Legislative Reapportionment, in MINORITY VOTE DILUTION, supra note 7, at 85.

209. 377 U.S. 533 (1964). The impact of Reynolds' theory of population-based representation on the structure of legislative delegations is discussed infra Part II(A)(2).

210. For a view of Reynolds as a case about enhancing the political power of white suburbanites, see Blacksher \& Menefee, supra note 167.

211. Reynolds, 377 U.S. at 562.

212. The Reynolds theory of vote dilution has been characterized as the quantitative prong of vote dilution theory. See Karlan, supra note 196, at 176 (describing quantitative and qualitative theories generally). The Reynolds approach, which focused on vote counting rather than on articulating a theory about the relationship of voting to the political process, has been criticized from its inception. See Blacksher \& Menefee, supra note 167 , at 4,11-12 (asserting that Reynolds addresses numbers at expense of representational considerations). 
Reynolds moved from the existing theory of voting rights, which prohibited absolute barriers to participation, to an approach based upon equalizing the power of different groups of voters who could otherwise register and vote freely. As the Court saw it, "the right of suffrage can be denied by a debasement or dilution of the weight of a citizen's vote just as effectively as by wholly prohibiting the free exercise of the franchise."213

In the aftermath of Reynolds, plaintiffs challenged election structures on the grounds that they submerged-or diluted-the votes of black voters. These cases became known as racial vote dilution cases. ${ }^{214}$ These plaintiffs claimed not that they were prevented from registering and voting, or that their votes were miscounted, but that their votes were less effective than those cast by white voters. As a numerical majority, the preferences of white voters invariably prevailed. ${ }^{215}$

In White $v$. Regester, ${ }^{216}$ the Supreme Court defined the test for racial vote dilution under the Constitution for the first time. ${ }^{217}$ White involved the validity of a reapportionment plan for the Texas House of Representatives. ${ }^{218}$ In sustaining the district court's finding of racial vote dilution, the Court articulated a "totality of the circumstances" test for determining the existence of this

213. Reynolds, 377 U.S. at 555 (emphasis added).

214. Smith v. Paris, 257 F. Supp. 901 (M.D. Ala. 1966), a case from Barbour County, Alabama, resulted in the first published opinion in a racial vote dilution case. See Karlan, supra note 196, at 184 n.45. Racial vote dilution cases actually lie in the middle of the spectrum of vote dilution litigation, which had its origins in the one-person, one-vote logic of Reynolds and has since been found to include claims of political vote dilution. See Davis v. Bandemer, 478 U.S. 1 (1986). The racial vote dilution cases developed along two separate lines: the constitutional cases litigated under the Equal Protection Clause prior to the amendment of section 2 of the Voting Rights Act, see infra notes 216-30 and accompanying text, and the statutory cases litigated after the amendment of section 2, see infra notes 231-44 and accompanying text.

215. Racial vote dilution theory differed from the Reynolds approach in one important respect. The one-person one-vote mandate has a quantitative dimension because it assures an individual right to have one's district represented in the legislature in proportion to its population, see supra note 212 and accompanying text, while the principles forbiding discriminatory racial apportionments have a qualitative dimension: racial groups have a right to equal influence in the outcome of elections vis-à-vis the majority group. Karlan, supra note 196 , at 176.

216. 412 U.S. 755 (1973).

217. The legislative history of amended section 2 describes White as "the leading pre-Bolden vote dilution case." S. REP. No. 417, 97th Cong., 2d Sess. 2 (1982), reprinted in 1982 U.S.C.C.A.N. 177, 179 [hereinafter SENATE REPORT]. By identifying an aggregate of factors, White offered more guidance than did earlier decisions on how electoral structures should be measured against Equal Protection standards. Compare White, 412 U.S. at 766-69, with Whitcomb v. Chavis, 403 U.S. 124, 149 (1971) (asking whether blacks were afforded an equal opportunity "to participate in the political processes and to elect legislators of their choice"); Burns v. Richardson, 384 U.S. 73, 88 (1966) (asking whether "a particular multi-member scheme effects an invidious result"); Fortson v. Dorsey, 379 U.S. 433, 439 (1965) (asking whether structure "minimize[s] or cancel[s] out the voting strength of racial or political elements of the voting population").

218. The State used multimember districts when electing members to the house of representatives for the eleven counties that included large metropolitan areas, but used single-member districts in the remainder of the state. The issue culminating in White concerned only the racially discriminatory aspects of multimember districts in Dallas and Bexar counties, 412 U.S. at 756, although the Court also considered whether the plan as a whole satisfied one-person, one-vote requirements. Id. On remand, the district court heard evidence that the remaining nine multimember districts were racially discriminatory. Graves v. Barnes, 378 F. Supp. 640 (W.D. Tex. 1974). 
phenomenon. ${ }^{219}$ The Court catalogued a number of political, social, and electoral factors supporting the finding that multimember districts discriminated against blacks in Dallas County, and Mexican-Americans in Bexar County. ${ }^{220}$ These factors included the history of de jure discrimination against blacks and Mexican-Americans in Texas, the lack of success of black and Mexican-American candidates in state legislative elections, the use of numbered place and majority vote requirements, ${ }^{221}$ appeals to race in the candidate slating and campaign processes, and the nonresponsiveness of the state legislative delegation. The ultimate question was whether the minority voters enjoyed "less opportunity than did other residents to participate in the political processes and to elect legislators of their choice."222 The election of representatives to office was one aspect of "effective participation in political life."223

Following White, the lower courts assessed vote dilution under this "results" test, but focused primarily on whether minority voters could elect candidates to office. The touchstone was whether minority voters were aggregated in a district or districts in high enough numbers that their votes were sufficient to elect one or more candidates. ${ }^{224}$ Where black voters and white voters vote differently, ${ }^{225}$ a districting plan that disaggregated minority voters by dividing

219. White, 412 U.S. at 769.

220. White, 412 U.S. at 766-69. These factors were catalogued more concisely in Zimmer v. McKeithen, 485 F.2d 1297, 1305 (5th Cir. 1973), aff $d$ sub nom. East Carroll Parish Sch. Bd. v. Marshall, 422 U.S. 636 (1976), in which the court held that minority votes can be diluted by "an aggregate of ... factors," including "a lack of access to the process of slating candidates, the unresponsiveness of legislators to [minority voters] particularized interests, a tenuous state policy underlying the preference for multi-member or at-large districting, or .... the existence of past discrimination in general [that] precludes the effective participation in the election system. ..." (footnote omitted). These factors are "enhanced by a showing of the existence of large districts, majority vote requirements, anti-single shot voting provisions and the lack of provision for at-large candidates running from particular geographic subdistricts." Id. These factors are now referred to as "primary" and "enhancing" factors.

221. Numbered place (or post) laws require candidates in multimember districts to fill designated seats, and voters to vote for one candidate for each seat. Davidson, supra note 104, at 7. Majority vote requirements mandate that only candidates receiving more than $50 \%$ of the votes cast will be declared winners, and require a runoff election between the top two candidates if neither receives a majority. Karlan, supra note 2, at 26-27. Both requirements can impair the voting strength of black voters. Laughlin McDonald, The Majority Vote Requirement: Its Use and Abuse in the South, 17 URB. LAw. 429 (1985) (acknowledging that majority vote requirements dilute black voting strength but concluding that abolition of such requirements would be counterproductive); Davidson, supra note 104, at 7 (numbered place laws).

222. White, 412 U.S. at 766. This test was later codified in section 2 of the Voting Rights Act, as amended. See infra notes 231-34 and accompanying text.

223. White, 412 U.S. at 769. The suggestion in White that participation includes access to a more extended political process, including the post-election activities of legislators themselves, is further explored infra Part IV.

224. In White, the Court focused on whether multimember districts provided black and MexicanAmerican voters with the opportunity to elect candidates, 412 U.S. at 765-66, although it reiterated its prior holding that the lack of proportional representation would not by itself sustain a racial vote dilution claim. Much of the early vote dilution litigation challenged at-large structures for the election of local governing bodies. See, e.g., Kirksey v. Board of Supervisors, 554 F.2d 139 (5th Cir.), cert. denied, 434 U.S. 968 (1977); Zimmer v. McKeithen, 485 F.2d 1297 (5th Cir. 1973) (en banc) (at-large elections for police jury and school board), aff $d$ sub nom. East Carroll Parish School Bd. v. Marshall, 424 U.S. 636 (1976) (per curiam).

225. Voting patterns in which "black voters and white voters vote differently," Thornburg v. Gingles, 478 U.S. 30,53 n.21 (1986), are called "racially polarized voting" or "racial bloc voting." In the absence 
them among different districts or submerging them in a larger district failed to satisfy this standard. ${ }^{226}$

Constitutional vote dilution theory took a sharp turn in Mobile $v$. Bolden. ${ }^{227}$ The plurality in Bolden rejected the "results" approach of earlier cases, and held that a finding of discriminatory intent is necessary to prove that an election system unconstitutionally dilutes the weight of minority votes. ${ }^{228}$ Although the totality of circumstances test might be used as evidence of discriminatory motive, it could not by itself establish intent. The only real issue was what was in the minds of the legislators-in this case, the legislative delegation-who were responsible for the election system. ${ }^{229}$ The Court thus reversed the district court's finding of discrimination and remanded the case for further proceedings. ${ }^{230}$

Congress responded to Bolden by amending section 2 of the Voting Rights Act in 1982 to clarify that discriminatory purpose was not an essential element of a vote dilution claim. ${ }^{231}$ Instead, an electoral system or other "standard,

of racial bloc voting, districting lines would have little relevance to whether candidates preferred by minority voters were successful.

226. At that time, elections for state and local offices shared features that diluted black voting strength. Elections for county and municipal office were held on either an at-large or a district basis, with some jurisdictions adopting election systems that included features of both. At the time, the "winner-take-all" feature of at-large elections was a well-known means of ensuring that the majority could always outvote the minority. See EDWARD C. BANFIELD \& JAMES Q. WILSON, CITY POLITICS 87-96, 307-09 (1965). Even in the absence of at-large elections, artfully drawn districts could fragment existing concentrations of minority voters. State legislators were elected from single-member districts, multimember districts, or a combination of both. Bernard Grofman, Alternatives to Single-Member Plurality Districts: Legal and Empirical lssues, 9 POL'Y STUD. J. 875, 889 n.1 (1981). While single-member districts could fragment minority voters, multimember districts could submerge minority votes in the same fashion as at-large elections. An at-large district is simply the largest possible multimember district for that jurisdiction, with the boundaries of the district identical to the jurisdiction's boundaries. Id. at 875 .

227. 446 U.S. 55 (1980). Under the city commission form of government, which Mobile had used since 1911 , the city was governed by three commissioners, elected by Mobile voters at large. Although the city's population was more than 35\% black, no black candidate had ever been elected to serve on the city commission. Id. at 97-98 (White, J., dissenting). The relevance of the Mobile decision to the powers of legislative delegations is discussed supra notes 143-47.

228. The plurality read White as "strongly indicating that only a purposeful dilution of the plaintiffs' vote would offend the Equal Protection Clause," id. at 69, in contrast to Zimmer, which was "quite evidently decided upon the misunderstanding that it is not necessary to show a discriminatory purpose in order to prove a violation of the Equal Protection Clause-that proof of a discriminatory effect is sufficient." Id. at 71. The plurality decision in Bolden was harshly criticized in the academic and legal communities. See, e.g., Kousser, How to Determine Intent, supra note 94, at 700 (plurality received "perhaps the most vociferous protest of any Supreme Court civil rights opinion since Brown"); Frank R. Parker, The "Results" Test of Section 2 of the Voting Rights Act: Abandoning the Intent Standard, 69 VA. L. REV. 715 (1983); Aviam Soifer, Complacency and Constitutional Law, 42 OHIO ST. L.J. 383 (1981). But see, e.g., James F. Blumstein, Defining and Proving Race Discrimination: Perspectives on the Purpose vs. the Results Approach from the Voting Rights Act, 69 VA. L. REV. 633 (1983).

229. 446 U.S. at 74 (describing "[d]iscrimination by white [city] officials" as "the most tenuous and circumstantial evidence" of discriminatory purpose).

230. After remand, the district court held that racial discrimination motivated the city to change its form of government in 1911, Bolden v. Mobile, 542 F. Supp. 1050, 1076 (S.D. Ala. 1982), that the system had been maintained for racial reasons, and that its effect was to deny blacks access to the political system. Id. at 1077.

231. SENATE REPORT, supra note 217, at 214-15 (noting that intent standard is "unnecessarily divisive" in requiring proof of racism; requires an "inordinately difficult" burden of proof; and "asks the wrong 
practice or procedure" that "results in a denial or abridgement" of the right to vote of members of racial or language minorities was prohibited. ${ }^{232} \mathrm{~A}$ violation of the statute is established where the "totality of circumstances" demonstrates that minority voters "have less opportunity than other members of the electorate to participate in the political process and to elect representatives of their choice.,233 The statutory language was taken directly from White $v$. Regester, whose definition of vote dilution was codified by the amendment. ${ }^{234}$

Finally, in Thornburg $v$. Gingles, ${ }^{235}$ the Supreme Court further defined the statutory test for one type of vote dilution, an "ability to elect" claim. ${ }^{236}$ In reviewing a challenge to North Carolina's multimember districts for electing state legislators, the Court stated that, "[t]he essence of a $\S 2$ claim is that a certain electoral law, practice or structure interacts with social and historical conditions to cause an inequality in the opportunities enjoyed by black and white voters to elect their preferred representatives."237 The Court found that of the seven factors identified in the senate report, the most significant for a claim of vote dilution in a multimember district was "the history and extent of

question"). In amending section 2, Congress stated that proof of discriminatory intent had never been an element of the statutory claim, noting that the amendment "restate[d] Congress' earlier intent that violations of the Voting Rights Act, including section 2, could be established by showing the discriminatory effect of the challenged practice." H.R. REP. No. 227, 97th Cong., 1st Sess. 29 (1981) (footnotes omitted). See also Thornburg v. Gingles, 478 U.S. 30 (1986); SENATE REPORT, supra note 217, at 179.

232. 42 U.S.C. $\S 1973($ a) (1988).

233. Id. $\$ 1973(\mathrm{~b})$. The statute provides that "[t]he extent to which members of a protected class have been elected to office . . . is one circumstance which may be considered . . ., "42 U.S.C. $\$ 1973(b)$, although this language was accompanied by the disclaimer that "nothing in this section establishes a right to have members of a protected class elected in numbers equal to their proportion in the population." Id. This latter proviso, known as the Dole Compromise, is explained in SENATE REPORT, supra note 217, at 363-64 (additional views of Senator Dole).

234. SENATE REPORT, supra note 217 , at 16,27 . A complete list of the factors derived from White's analytical framework is provided in the senate report. These "typical" factors include:

1. [T] he extent of any history of official discrimination in the state or political subdivision that touched the right of the members of the minority group to register, to vote, or otherwise to participate in the democratic process;

2. the extent to which voting in the elections of the state or political subdivision is racially polarized;

3. the extent to which the state or political subdivision has used unusually large election districts, majority vote requirements, anti-single shot provisions, or other voting practices or procedures that may enhance the opportunity for discrimination against the minority group;

4. if there is a candidate slating process, whether the members of the minority group have been denied access to that process;

5. the extent to which members of the minority group in the state or political subdivision bear the effects of discrimination in such areas as education, employment and health, which hinder their ability to participate effectively in the political process;

6. whether political campaigns have been characterized by overt or subtle racial appeals;

7. the extent to which members of the minority group have been elected to public office in the jurisdiction.

SENATE REPORT, supra note 217 , at 206-07 (footnotes omitted).

235. 478 U.S. 30 (1986).

236. Id. at 46. The plaintiffs' theory of the case was that the legislature's choice of multimember districts, rather than single-member districts, submerged concentrations of black voters and impaired their ability to elect their candidates of choice.

237. Id. at 47 . 
minority electoral success and of racial bloc voting."238 In addressing the plaintiffs' theory that the redistricting diluted the votes of black voters through "submergence in multimember districts," focused on electoral outcomes under the challenged system: "a bloc voting majority must usually be able to defeat candidates supported by a politically cohesive, geographically insular minority group."240 The Court took what it called a "functional" view of the political process, and suggested that this standard might vary with the type of dilution claim asserted. ${ }^{241}$

Since Gingles, the section 2 "results" test has provided the cornerstone for protecting and enforcing voting rights. ${ }^{242}$ Litigation under amended section

238. Id. at 49 n.15 (citation omitted). The Court has been criticized for articulating a test that bypasses the remaining factors listed in the senate report. See Abrams, supra note 195, at 464-65.

239. Gingles, 478 U.S. at 48.

240. Id. at 49 (emphasis in original). Gingles thus appeared to hold that in order to make out a claim of vote dilution in a multimember district, a minority group must be able to show "that [it] is sufficiently large and geographically compact to constitute a majority in a single-member district." Id. at 50 n.16. In the wake of Gingles, some courts have treated geographic compactness as a threshhold requirement of a claim. See, e.g., McGhee v. Granville County, 860 F.2d 110, 117 (4th Cir. 1988); McNeil v. Springfield Park Dist., 666 F. Supp. 1208, 1211 (C.D. III. 1987), aff d, 851 F.2d 937 (7th Cir. 1988), cert. denied, 490 U.S. 1031 (1989). But see Dillard v. Baldwin County Bd. of Educ., 686 F. Supp. 1459, 1465-66 (M.D. Ala. 1988). Professor Karlan has argued persuasively that Gingles should not be read to impose geographic compactness as a threshold requirement for a finding of vote dilution. See Karlan, supra note 196, at 199213.

241. 478 U.S. at $48 \mathrm{n}$.15. Although the Court did not attempt an exhaustive list of all the possible forms of vote dilution, it specifically identified two other means of dilution in addition to multimember district submergence: the use of multimember districts to impair the ability of a minority group to influence elections (in a district where the group would form a substantial proportion but not a majority of the district's population), id. at $46-47 \mathrm{n} .12$, and splitting a concentration of minority voters between two or more districts so that the group constituted a majority in neither district. Id. The Court's cautious view of the application of its standards to these factual situations is somewhat puzzling, given the obvious similarities between a gerrymander case and the claim asserted by the Gingles plaintiffs, see Paige v. Gray, 538 F. 2d 1108, 1110 n.l (5th Cir. 1976) ("[C]ourts have not hesitated to apply recent [at-large] dilution cases to solve redistricting problems.") (citations omitted), and the Court's own suggestion that a geographic compactness requirement would probably apply to a gerrymander case. Gingles, 478 U.S. at 50 n.16. See Karlan, supra note 196, at 199-204 for an incisive criticism of the Court's failure to provide guidance conceming the application of its holding in other factual contexts.

242. Jeffers v. Clinton, 730 F. Supp. 196, 202 (E.D. Ark. 1989) (three-judge court) ("[Gingles] is the pole star of the law."), aff $d, 111 \mathrm{~S}$. Ct. 662 (1991). Although Section 2 also forbids intentional discrimination, Garza v. County of Los Angeles, 918 F.2d 763, 766 (9th Cir. 1990), cert. denied, 111 S. Ct. 681 (1991), a court would rarely reach the constitutionality of a challenged election structure because courts are admonished to resolve constitutional issues only if other grounds are unavailable, Escambia County v. McMillan, 466 U.S. 48 (1984) (per curiam); Hagans v. Levine, 415 U.S. 528, 546-47 (1974). Because the results test of section 2 typically is easier to meet than an intent test, most cases are resolved without considering the purpose behind the election system. See McDonald, supra note 13, at 1279-81 (describing acceleration of litigation and increased success by plaintiffs under section 2). But see Garza v. County of Los Angeles, 756 F. Supp. 1298, 1303-04 (C.D. Cal.) (finding districting plan discriminatory both in purpose and effect), aff d, 918 F.2d 763, 771 (9th Cir. 1990), cert. denied, 111 S. Ct. 662 (1991). Moreover, discriminatory intent has the same meaning under section 2 as under the Constitution. Garza, 756 F. Supp. at 1349; Brown v. Board of Comm's, 722 F. Supp. 380, 383 (E.D. Tenn. 1989). Although Gingles did not discuss Congress' authority to enact civil rights statutes such as section 2 that provide protections beyond those afforded by the Constitution, it is well-established that Congress may do so. See Karlan, supra note 2, at 14 (Morgan power supports constitutionality of amended section 2); see also Stephen L. Carter, The "Morgan" Power and the Forced Reconsideration of Constitutional Decisions, 53 U. CHI. L. REV. 819 (1986) (arguing that the Morgan power is best understood as form of moral discourse). The continuing importance of section 5 to the resolution of voting rights questions is discussed supra notes 437-51 and 
2 since Gingles has centered on the "ability to elect" aspect of vote dilution. ${ }^{243}$ If a state or locality chooses to make an office an elected office, ${ }^{244}$ then the method of election for that position may be examined in terms of its effect on the ability of minority voters to elect candidates to that office.

In Gingles, the Court faced far less sweeping issues than it had in earlier decisions. The critical issue in Gingles was the impact of congressional action on the standard for measuring vote dilution in the familiar context of multimember districts. ${ }^{245}$ Although the answer to this question was neither easy nor unimportant, there was little question that multimember districting plans could impair black voting strength under some circumstances. ${ }^{246}$ The Court was not required to define either the starting or ending point of political participation, or to assess how to measure dilution at a different stage.

accompanying text.

243. Although the language of section 2 speaks broadly of the opportunities for minority voters to participate in the political process, see supra text accompanying note 233 , few cases filed under section 2 have challenged electoral practices other than discriminatory election systems. Whitfield v. Democratic Party of Arkansas, 890 F.2d 1423, 1427 (8th Cir. 1989) ("IV]irtually all of the cases decided under section 2 deal with at-large elections or legislative districting matters."), rev' $g$ 686 F. Supp. 1365 (E.D. Ark. 1988), aff $d$ on reh'g en banc by an equally divided court, 902 F.2d 15 (8th Cir. 1990), cert. denied sub nom. Whitfield v. Clinton, 111 S. Ct. 1089 (1991). Claims that electoral participation has been abridged may be more difficult to assert after Chisom v. Roemer, 111 S. Ct. 2354 (1991), where the Court noted that section 2 claims must allege an abridgement of the opportunity "to participate in the political process and to elect representatives of one's choice," id. at 2365 (emphasis in original), and that to separate these two aspects of section 2 would require "radical surgery." Id. This language implies that section 2 does not protect the opportunity of minority groups to participate in the political process in the absence of an impact on election results. This interpretation is at odds with the prevailing view that Congress intended to protect a broad spectrum of political rights, not just the ability to elect candidates. See, e.g., Abrams, supra note 195, at 458-59, 475-76; Guinier, Triumph of Tokenism, supra note 195, at 1094-95; Karlan, supra note 196, at 19699.

244. For a discussion of the parameters of an elected office, see infra notes $386-88$ and accompanying text. The applicability of section 2 does not depend on the function performed by the elected officials, Chisom, 111 S. Ct. at 2366; Houston Lawyers' Ass'n v. Texas, 111 S. Ct. 2376 (1991). Before the Court in Houston Lawyers' rejected the so-called "single-member office theory," $111 \mathrm{~S}$. Ct. at 2381 , several courts had used this theory to exclude from section 2 coverage any elected position in which the officeholder served as a member of a single-member rather than a multimember body. See, e.g., United States v. Dallas County Comm'n, 850 F.2d 1430, 1432 n.1 (11th Cir. 1988) (judicial aspect of office of probate judge), $r e h^{\prime} g$ denied, 858 F.2d 746 (11th Cir. 1988), cert. denied, 111 S. Ct. 681 (1991); Butts v. City of New York, 779 F.2d 141, 148 (2d Cir. 1985) (mayor), cert. denied, 478 U.S. 1021 (1986). But see Carrollton Branch of NAACP v. Stallings, 829 F.2d 1547 (11th Cir. 1987), cert. denied sub nom. Duncan v. Carrollton, 485 U.S. 936 (1988) (single-commissioner county government subject to section 2 challenge where purpose alleged). For a penetrating criticism of the single-member office exception, see Karlan, supra note 2.

245. See Abrams, supra note 195, at 451-52 (vast majority of voting rights cases during first two decades following passage of Act dealt with elections for multimember bodies).

246. In Chisom, $111 \mathrm{~S}$. Ct. at 2361 , the Court recently reiterated that section 2 protects political participation beyond the formal right to vote, stating that "there is no question that [the language of section 2 is] broad enough to encompass the use of multimember districts to minimize a racial minority's ability to influence the outcome of an election." Even before Chisom was decided, most commentators agreed with this interpretation of section 2, see, e.g., Abrams, supra note 195, at 453-55; Karlan, supra note 196, at 18385, but there were dissenters, see, e.g., ABIGAIL THERNSTROM, WHOSE VOTES COUNT?: AFFIRMATTVE ACTION AND MINORTTY VOTING RIGHTS (1987) (section 2 only guarantees formal right to enter voting booth); Abigail Themstrom, The Odd Evolution of the Voting Rights Act, 55 PUB. INTEREST 49 (1979). 


\section{The Post-Election Phase}

In contrast to the stages involving electoral participation and the actual election of candidates, the post-election phase looks to the way electoral power is used, rather than to the way it is gained. Because the post-election phase considers the process by which legislative decisions are reached, this stage examines the powers and duties of elected bodies (and individual elected officials), as well as legislative structures such as legislative rules and procedures, committee assignments and the like. ${ }^{247}$ How do these legislative functions $^{248}$ hinder representatives elected by minority voters, and thus restrict the ability of these voters to cast meaningful ballots?

Before the recent Supreme Court decision in Presley, section 5 clearly reached the post-election phase but questions remained about the scope of a voting powers analysis premised on the allocation of power among various governmental actors. The language of the Act suggested an expansive interpretation of the right to vote, ${ }^{249}$ as did the views of several commentators. ${ }^{250}$ The federal courts ${ }^{251}$ and the Justice Department ${ }^{252}$ concurred that section

247. Put simply, powers and duties are what the legislature does, whereas rules and procedures are how the legislature goes about doing what it does.

248. The term "legislative function" suggests that powers, duties, and rules and procedures are simply different aspects of the decisionmaking process. They are conceptually intertwined in the sense that rules and procedures affect the powers and duties of legislators by including (or excluding) them from the decisionmaking process.

249. Section 14(c)(1) defines "vote" and "voting" to include "all action necessary to make a vote effective ... with respect to candidates for public or party office." 42 U.S.C. $\$ 1973$ l (c)(1) (1988). Section 5 carries out this mandate by scrutinizing "any voting qualification or prerequisite to voting, or standard, practice, or procedure with respect to voting." 42 U.S.C. $\$ 1973 \mathrm{c}$.

250. See, e.g., Guinier, supra note 29 , at 1504 ("'C]hanges that affect the minority representatives' authority and power to decide particular legislative issues should be scrutinized under section 5"); Karlan, supra note 196, at 180 (urging courts to "look beyond the voting booth to the council chamber and the 'voting' (decision-making) that occurs there").

251. The courts held in four cases that section 5 reached the change in question. Robinson v. Alabama State Dep't of Educ., 652 F. Supp. 484 (M.D. Ala. 1987) (three-judge court) (transfer of authority over city schools from elected county school board to appointed city school board), aff $d, 918$ F.2d 183 (11th Cir. 1990); Hardy v. Wallace, 603 F. Supp. 174 (N.D. Ala. 1985) (three-judge court) (transfer of appointment power over county racing commission from legislative delegation to governor); County Council v. United States, 555 F. Supp. 694 (D.D.C. 1983) (three-judge court) (transfer of authority from state legislature, govemor, and legislative delegation to county council); Horry County v. United States, 449 F. Supp. 990 (D.D.C. 1978) (three-judge court) (transfer of administrative functions from chairperson elected at large to administrator appointed by city council). In a fifth case, the court held that the transfer of road supervision authority from individual commissioners to the holdover commissioners was covered, while changes which altered the spending authority of individual commissioners and transferred road operations to the county engineer were not. Mack v. Russell County Comm., No. 89-T-459-E (M.D. Ala. Aug. 1, 1990) (three-judge court) (transfers of decisionmaking authority), aff'd sub nom. Presley v. Etowah County Comm., $112 \mathrm{~S}$. Ct. 820 (1992) (no appeal taken from ruling that road supervision change covered). In a sixth case, Rojas v. Victoria Independent School District, No. V-87-16, 1988 WL 92053 (S.D. Tex. Mar. 29, 1988) (threejudge court), aff $d, 490$ U.S. 1001 (1989) (mem.), the court found that the "de minimis import" of the agenda policy at issue placed it outside of section 5 , id. at *2, but expressly declined to exempt all actions that "[lie] beyond the actual election process" from section $5 . I d$. at *1.

252. Comments, Final Rule, Revision of Procedures for the Administration of Section 5 of the Voting Rights Act of 1965, 52 Fed. Reg. 486, 488 (1987) [hereinafter Comments]; 28 C.F.R. § 51.15 (1991) (enabling legislation for political subunits covered under section 5). Before Presley, the Justice Department 
5 covered actions taking place after election day, although they drew different distinctions between changes that implicated voting and those that did not. ${ }^{253}$ Although the Supreme Court had not reached the question prior to Presley, one decision, City of Lockhart $v$. United States, ${ }^{254}$ suggested an interpretation of section 5 that would include powers and duties, while a second decision, McCain v. Lybrand, ${ }^{255}$ remained neutral.

reviewed numerous submissions involving reallocations of the authority of individual officeholders and elected bodies and objected to changes of this type on at least eight occasions. Brief for the United States as Amicus Curiae Supporting Appellants at 16-17 and n.6, Presley v. Etowah County Comm'n, $112 \mathrm{~S} . \mathrm{Ct}$. 820 (1992) (Nos. 90-711 and 90-712) [hereinafter Brief for the United States]. These decisions spanned a fourteen-year period, with the most recent decision rendered on May 7, 1990 (San Patricio, Texas: transfer of voter registration duties from county clerk to county tax authority) and the earliest on March 2, 1976 (Mobile, Alabama: transfer of administrative functions from city commission to individual commissioners). In some instances, these changes implicated home rule because authority was transferred from one level of government to another. See, e.g., Hillsborough County, Florida (Aug. 29, 1984) (transfer of power over municipalities from legislative delegation to county commission; objection withdrawn after change revoked); City of Brunswick and Glynn County, Georgia (Aug. 16, 1982) (transfer of power from separate city and county commissions to consolidated commission); Colleton County, South Carolina (Sept. 4, 1979) (transfer of school taxing authority from legislative delegation to county council); Edgefield County, South Carolina (Feb. 8, 1979) (transfer of increased taxing power to county council); Charleston County, South Carolina (June 14, 1977) (transfer of taxing authority from legislative delegation to county council). Brief for the United States, supra, at 16 n.6.

253. In its amicus brief in Presley, the Department offered the following test: "[T]ransfers of authority that implicate an elected official's decisionmaking authority are covered by Section 5," while "[c]hanges that do not affect an offical's power to make decisions generally have no such potential to dilute the power of a citizen's vote." Brief for the United States, supra note 252, at 17-18. The courts have applied several tests in evaluating these changes. See, e.g., Mack v. Russell County Comm., No. 89-T-459-E, slip op. at 19 (M.D. Ala. Aug. 1, 1990) (appropriate standard is whether changes "effect a significant relative change in the powers exercised by govemmental officials elected by, or responsible to, substantially different constituencies"); Hardy, 603 F. Supp. at 179 (describing relevant attributes of modifications of governmental duties that fall within reach of section 5); Horry County, 449 F. Supp. at 995 (change that "reallocates governmental powers among elected officials voted upon by different constituencies" is covered by section 5).

254. 460 U.S. 125 (1983). The City of Lockhart, Texas, changed its form of govermment from a commission, consisting of a mayor and two commissioners, to a city council, consisting of a mayor and four councilmembers. The commission was elected at large, using a "numbered-post" system in which each candidate filed for a separate seat. See supra note 221 for a discussion of numbered posts. Under the new system, these officials continued to be elected at-large from numbered posts, but the city expanded its governing body and added staggered terms to which councilmembers were elected in alternate years. The city conceded that the increase in the body's size and the addition of staggered terms were covered changes, but argued that the two "continuing" council seats could not be reviewed for discrimination because they had not changed: there were two "numbered" at-large seats under both the new and old systems.

The Court rejected this argument, and instead evaluared the relative position of the numbered post seats under the old and new system in terms of their relationship to the governing body: "In moving from a three-member commission to a five-member council, [the city] has changed the nature of the seats at issue. . . . For example, [the two old seats] now constitute only $40 \%$ of the council, rather than $67 \%$ of the commission." 460 U.S. at 131. In effect, the change reallocated the authority of the individuals holding the at-large seats. Although their formal powers had not changed, they functionally possessed different powers on a three-member body than on a five-member body.

255. 465 U.S. 236 (1984). McCain does not undercut the argument that reallocations of governmental authority are covered by section 5 . The question before the Court was whether the Attorney General had precleared the changes incorporated in a 1966 South Carolina statute. Because the parties had stipulated that the statute incorporated voting changes, the Court simply observed that "several changes are suggested," including "the basic reallocation of authority from the state legislative delegation to the [county council]." Id. at $250 \mathrm{n} .17$. The Court held that preclearance had not been obtained, id. at 254, 257-58, and remanded the case to the district court to identify the covered changes. 
Although the question of whether a particular change is covered requires a case-by-case determination, ${ }^{256}$ all decisions applying section 5 standards to changes in the political system's distribution of power assume that the power of a person's vote is dependent upon the power held by his or her elected representatives. ${ }^{257}$ To strip a representative of all power renders the vote for that office meaningless, while a diminution or transfer of these powers can reduce the effectiveness of constituents' votes. Whatever the limits of this analysis, the few decisions that concern reallocations of authority apply a concept of voting rights that looks beyond the voting booth.

Presley, however, effectively blocked the use of section 5 against discrimination in the post-election stage by holding that "[c]hanges which affect only the distribution of power among officials are not subject to $\S 5$ because such changes have no direct relation to, or impact on, voting.

In Presley, the Court considered changes in the powers and duties of elected members serving on the county commissions of Etowah and Russell Counties, Alabama, whose "principal function [was] to supervise and control the maintenance, repair, and construction of the county roads."259 In Etowah County, each individual county commissioner traditionally determined how to spend the road funds allocated to his or her district. But nine months after the county's first black commissioner took office, the four holdover members altered this longstanding practice via the "Common Fund Resolution," which transferred spending authority for road funds to the Commission as a whole. The Russell County Commission also abolished individual road districts and, through a "Unit System," transferred the responsibility of individual commissioners for road operations to the appointed county engineer. The federal district court found these changes to be outside the scope of section $5,{ }^{260}$ and the Supreme Court affirmed.

The Court read its previous section 5 holdings as presenting only four categories of voting changes: changes in "the manner of voting"; changes in

256. The Justice Department has declined to specify all possible covered changes, noting that "we do not believe that a sufficiently clear principle has yet emerged distinguishing covered from noncovered reallocations to enable us to expand our list of illustrative examples [of covered changes] in a helpful way." Comments, supra note 252, at 488.

257. See, e.g., Robinson v. Alabama State Dep't of Educ., 652 F. Supp. 484, 485-86 (M.D. Ala. 1987) (three-judge court), aff d, 918 F.2d 183 (11th Cir. 1990); Hardy v. Wallace, 603 F. Supp. 174, 178 (N.D. Ala. 1985) (three-judge court). These cases should be viewed as the logical successors to Reynolds v. Sims, 377 U.S. 533 (1964), in which the right to vote also was considered a right to equal voting power. Although the Court did not expressly use the term "power" when describing the protected right, its concept of "oneperson, one-vote" reflects a concern with voting power. All Alabama voters literally cast the same number of votes, but the plaintiffs" votes were "undervalued." Id. at 563. The only difference is that Reynolds looked at voting power from the perspective of election day, whereas these cases look beyond election day to the duties actually performed by elected officials.

258. Presley v. Etowah County Comm'n, I12 S. Ct. 820, 830 (1992).

259. Id. at 824.

260. Mack v. Russell County Comm'n, No. 89-T-459-E (M.D. Ala. Aug. 1, 1990). The parties did not appeal the district court's holding that a resolution precluding two newly-elected commissioners from exercising road supervision authority was covered by section 5 . 
"candidacy requirements and qualifications"; changes in "the composition of the electorate that may vote for candidates for a given office"; and finally, changes "affecting the creation or abolition of an elective office." Court found that the changes at issue fell outside this description because "[t]hey had no impact on the substantive question whether a particular office would be elective or the procedural question how an election would be conducted," and thus could not be considered rules governing voting. ${ }^{262}$

Presley leaves little room to argue that voting power is compromised by changes in the individual or collective powers and duties of elected officials, or by changes in the internal operating procedures of governing bodies. Unless a transfer of decisionmaking authority eviscerates an official's responsibilities, ${ }^{263}$ the logic of Presley affords no remedy under the Voting Rights Act for post-election stage discrimination. ${ }^{264}$ In Part IV, I revisit the post-election phase to consider the real world implications of Presley in the context of legislative delegations and to suggest other avenues of relief.

\section{RIGHTS AND REMEDIES: Delegation DILUTION AND THE Voting RIGHTS ACT}

Legislative delegations have played a behind-the-scenes role in Voting Rights Act litigation. They were responsible for establishing Mobile, Alabama's unconstitutional election system ${ }^{265}$ and were the object of racial maneuvering in Greene County, Alabama. ${ }^{266}$ Despite the fact that delegations have been responsible for many discriminatory election practices, the methods and factors determining a delegation's composition, whether they be reapportionment or annexation, have not been examined. A thorough examination of delegations

261. Presley, 112 S. Ct. at 828.

262. Id. at 832 . Although the Court said it was not "implying that the four typologies exhaust the statute's coverage," $i d$. at 828 , this caveat seems more reflexive than sincere. The Court relied heavily on this typology in excluding changes in the power of elected bodies, id. at 829-30, and reiterated it in excluding the specific changes at issue. $I d$. at 832 . Thus, the opinion should be read as limiting the reach of section 5 to this four-part typology.

263. The Court left open the possibility that, under some circumstances, the transfer of duties from an elected to an appointed official might amount to a de facto substantive decision replacing an elected office with an appointed one, $112 \mathrm{~S}$. Ct. at 831 , but the decision suggests that this would be the exceptional case.

264. The Court suggested that other legal theories might apply: "Nothing we say implies that the conduct at issue in these cases is not actionable under a different remedial scheme. The Voting Rights Act is not an all-purpose antidiscrimination statute." Presley, $112 \mathrm{~S}$. Ct. at 832 . The decision in Presley stands in sharp contrast to earlier decisions in which the Court made courageous leaps of faith in articulating new theories to combat impairments of voting power. In Reynolds the Court boldly created new conceptions of voting equality, see supra notes 209-13 and accompanying text. In White, the Court drew on Reynolds to articulate a theory combating the opinion's otherwise majoritarian thrust and furthering minority representation. See Blacksher \& Menefee, supra note 167, at 5, 37 (describing Reynolds as majoritarian).

265. See supra notes $143-47$ and accompanying text.

266. See supra notes $46-51$ and accompanying text. 
demonstrates that their structure should be held accountable to the demands of the Voting Rights Act.

An analysis of delegations also helps reveal the limits of the standard vote dilution theory developed in other contexts. As described in Part II, vote dilution theory traditionally holds that discrimination occurs when black voters enjoy less opportunity to elect candidates of their choice than do their white counterparts. Voting rights doctrine would treat delegations differently depending on whether they are considered to be "superlegislatures," and hence similar to elected bodies, or simply parts of the legislative process, akin to legislative committees. ${ }^{267}$ For delegations to fit into the electoral phase of standard voting rights jurisprudence, they must be characterized as formal governing bodies, analogous to city councils and county commissions.

Although a complete understanding of the status of delegations must await the more detailed analysis later in this Part, it is worthwhile at this juncture to note that a functional view of the political process does suggest the framework of an answer. This perspective yields a striking image of delegations as elected bodies that are the functional equivalents of local governing bodies. ${ }^{268} \mathrm{Like}$ other governmental entities, delegations have defined memberships as well as jurisdiction over legislation affecting their counties. Each delegation meets as a group to determine its position concerning a local bill. Delegations are granted a large degree of autonomy within the legislature, and their decisions are rarely overridden. In effect, the legislature has delegated its control over local matters to the legislators from each locality.

Under this functional view, legislative delegations share with the local governing body responsibility for legislation concerning local matters. The extent to which they share responsibility depends upon the relative degree of home rule allowed by the state. Where cities and counties enjoy little home rule, delegations exercise more control over local matters; where home rule is more extensive, on the other hand, delegations play a less important role in local governance. However, delegations operate in either scenario as de facto

267. Presley cited changes in committee structure as an example of an "enactment ... having nothing to do with voting." $112 \mathrm{~S}$. Ct. at 829 . Despite the enormous literature on legislative committees, political scientists have offered few helpful definitions. See Heinz Eulau \& Vera McCluggage, Standing Committees in Legislatures, in HANDBOOK, supra note 20, at 395-96 (describing committees as a "collective unit of action" that mediates roles of legislator as individual member, as committee member, and as part of legislature as whole).

268. Delegations are often described as if they were formal bodies. See, e.g., CHESTNUT \& CASS, supra note 106, at 291 (stating that "[t]here were no blacks in our local delegation then"); Robert B. McNeil, States News Service, Oct. 20, 1989, available in LEXIS, Nexis Library (untitled) (describing State Sen. Hank Sanders and State Rep. Lucius Black as first "black legislative delegation" from western Alabama). Even a cursory reading of most local newspapers in the South reveals that day-to-day deliberations of delegations often receive more attention than activities of the state legislature as a whole. 
legislatures for local jurisdictions. ${ }^{269}$ What, then, is the potential for discrimination in the selection of delegation members?

\section{A. Method of Determining Delegations' Composition: Reapportionment, Annexation, and Delegation Gerrymanders ${ }^{270}$}

The major determinant of who sits on legislative delegations is the legislative reapportionment process. As we have seen, a delegation comprises those legislators whose districts include some portion of the county. By changing legislative district lines, the legislature influences not only who is elected to the state legislature, but also who serves on the legislative delegation for each city and county in the state. Although annexations can affect the membership of city delegations, they rarely have an impact on county delegation membership. ${ }^{271}$ Because legislative reapportionment is the only structural change that has great potential to affect both city and county delegations, the impact of reapportionment on delegation membership is the major focus of this section. ${ }^{272}$

If legislative delegations are akin to local governing bodies, then each legislative reapportionment is also a reapportionment of the delegation. ${ }^{273} \mathrm{By}$ simply extending a district line across a county boundary to take in a small piece of an adjoining county, the resulting legislative district and the voters within it become part of the governance system for that county. By becoming a member of the county's legislative delegation, that district's legislator can influence the deliberations of that body and can propose or block legislation sponsored by other delegation members. This phenomenon can lead to discrimination against minority voters.

269. Because delegations do not have the status of formal governing bodies, the analogy is not exact. Although delegation members serve because they have been elected by a designated district, they do not run for an office identified as "legislative delegation member." Instead, legislators become members as a result of longstanding legislative practice or legislative rules. Moreover, while delegations play a critical role in passing local legislation, the legislature as a whole can refuse to follow the tradition of local courtesy.

270. The term "gerrymander" is derived from a combination of the words Gerry and salamander, describing the salamander-shaped legislative district that Massachusetts Governor Elbridge Gerry approved. DIXON, supra note 17, at 459 n.2. Although in popular usage, "gerrymander" refers to the practice of seeking political advantage by drawing bizarrely shaped districts, it is commonly understood that a district need not have been assigned an irregular shape to affect the political advantage of different groups. Id. at 459-60; see also Bernard Grofman, Criteria for Districting: A Social Science Perspective, 33 UCLA L. REV. 77, 89-93 (1985) (noting district's shape not conclusive evidence of gerrymandering).

271. Blanton v. Campbell, No. 2-91-3635-1 (D.S.C. amended complaint filed Dec. 12, 1991), the South Carolina litigation discussed supra note 21 , is an exception to the general rule that county boundaries seldom change. See supra note 39.

272. Nonetheless, my proposals for the measure of dilution that should be applied to delegation reapportionments would also be applicable to annexations affecting delegation membership. See infra Part II(B)(3).

273. In order to avoid confusing these two distinct concepts, I shall refer to one type of reapportionment as "legislative reapportionment" and to the other as "delegation reapportionment." 


\section{Legislative Reapportionments}

Legislative reapportionments vary widely in scope and form. A reapportionment may create or eliminate districts, aggregate districts electing a single legislator to form a larger district that elects several representatives (commonly referred to as a multimember district), or simply redraw district lines between existing legislative districts. The Supreme Court has noted that "[d]istrict lines are rarely neutral phenomena."274 As one commentator has explained, "the key concept to grasp is that there are no neutral lines for legislative districts .... [E]very line drawn aligns partisans and interest blocs in a particular way different from the alignment that would result from putting the line in some other place."275 Changes of this type affect the voting influence of individuals and groups because such changes alter the contours of legislative districts, which in turn determine who is elected to office.

The legislative reapportionment of the Indiana House of Representatives, challenged in Davis v. Bandemer, ${ }^{276}$ illustrates this phenomenon. In 1981, the Republicans, who controlled both houses of the state legislature, adopted a districting plan for the 100 seats in the house of representatives. ${ }^{277}$ Democrats runnning for house seats in the first election after this reapportionment plan received 51.9 percent of the votes cast in the election, but won only 43 percent of the seats. ${ }^{278}$ Thus, alternative reapportionment proposals would likely have yielded a Democratic majority in the house; the legislative reapportionment plan was a significant factor in determining which party would control the legislature $^{279}$ and what the relative voting power of Democratic and Republican voters would be. Those citizens who voted for Republican candidates benefited

274. Gaffney v. Cummings, 412 U.S. 735,753 (1973) (holding that minor population variations do not make out prima facie case of invidious discrimination under Equal Protection Clause).

275. Robert G. Dixon, Fair Criteria and Procedures for Establishing Legislative Districts, in REPRESENTATION AND REDISTRICTING IsSUES 7-8 (Bernard Grofman, et al. eds., 1982). This view of the nature of reapportionment is shared by numerous commentators.

276. 478 U.S. 109 (1986). In Davis, the plaintiffs alleged that the apportionment plan deprived them of the opportunity to control the legislature. Id. at 115-16. Most challenges occur in settings where plaintiffs are unlikely to control the legislature and the claim is that a legislative apportionment gives plaintiffs fewer seats than would a "fair" plan. See, e.g., Whitcomb v. Chavis, 403 U.S. 124, 128-29 (1971) (challenge by minority voters to multimember election system that reduced opportunity to elect representatives). But see Ketchum v. Byrne, 740 F.2d 1398 (7th Cir. 1984) (suggesting alternate remedy), cert. denied, 471 U.S. 1135 (1985).

277. The plan provided for 61 single-member districts, nine double-member districts, and seven triplemember districts. Davis, 478 U.S. at $113-14$ \& n.2.

278. Even more extreme was the situation in Marion and Allen counties, where Republicans won $86 \%$ of the legislative seats allocated to the counties, despite the fact that Democratic voters accounted for $46.6 \%$ of the population. Id. at 134 .

279. Nevertheless, the legislative reapportionment was not the only factor. Even if the legislature had a goal of fairly reflecting the political strength of both parties, see Gaffney v. Cummings, 412 U.S. 735, 753 (1973), each party would not necessarily have won a proportionate number of legislative seats. This phenomenon is characteristic of winner-take-all systems in which the relevant population is unevenly distributed. See Howard M. Shapiro, Note, Geometry and Geography: Racial Gerrymandering and the Voting Rights Act, 94 YALE L.J. 189, 202, 205 (1984) (discussing the constraints that proportional representation schemes present for minority groups). 
under the plan, while those supporting Democratic candidates were disadvantaged. $^{280}$

When reviewing reapportionments, courts have made only passing references to legislative delegations, ${ }^{281}$ instead focusing on the plan's effect on a group's ability to elect candidates to the state legislature. Nonetheless, the reapportionment of legislative delegations, like any other form of reapportionment, can be manipulated to increase the influence of particular groups of voters. Therefore, whenever reapportionment curtails black voters' influence on the election of members of the legislative delegation, the Voting Rights Act should govern.

\section{Fragmented and Submerged Counties: The Legacy of the One-Person, One-Vote Principle}

Despite the close resemblance of legislative delegations to local governing bodies, the one-person, one-vote principle of legislative reapportionment often prevents legislative delegations from being truly "local."

Several decades ago, the fit between county boundaries and membership on legislative delegations was fairly close. ${ }^{282}$ Yet since the implementation of the one-person, one-vote principle, the boundaries of legislative districts no longer conform to county boundaries. Typically, counties are split between two or more legislative districts, or are submerged in a legislative district that includes two or more counties. ${ }^{283}$ Today, members of a legislative delegation often reside outside counties that are subject to their jurisdiction, and are therefore elected by noncounty voters.

Stated most simply, the one-person, one-vote rule means that legislative districts must contain, to the extent practicable, equal numbers of people. ${ }^{284}$ Reapportionment cases premised on this one-person, one-vote principle recognize that in drawing legislative districts, there is an inherent tension between adhering to political subdivision boundaries and minimizing population varianc-

280. This discussion evaluates the relative advantages of the plan for Democratic and Republican voters as a whole, rather than as individuals. For, under the plan, some Democratic voters in certain districts elected the candidates of their choice, while certain Republican voters did not. Voting rights scholarship often focuses on group rights instead of individual rights. See, e.g., Abrams, supra note 195, at 453-54 (describing vote dilution as group pattern rather than individual right); Karlan, supra note 196, at 176 (discussing qualitative vote dilution as group phenomenon).

281. See, e.g., Whitcomb v. Chavis, 403 U.S. 124, 133, 146-48, 155 (1971).

282. See supra notes $77-84$ and accompanying text.

283. See JEWELL, CONTEMPORARY SOUTH, supra note 80, at 126-27; JEWELL, supra note 131, at 60; Robert G. Dixon, Jr., The Court, the People, and 'One Man, One Vote', in REAPPORTIONMENT N THE 1970s, supra note 126 , at 7 n.1.

284. See Reynolds v. Sims, 377 U.S. 533, 577 (1964) ("[T]he Equal Protection Clause requires that a State make an honest and good faith effort to construct districts, in both houses of its legislature, as nearly of equal population as is practicable."). 
es among districts. ${ }^{285}$ If adherence to boundaries such as county lines would result in significant population disparities among legislative districts, then those political demarcations must be disregarded. ${ }^{286}$ Although courts have given some weight to maintaining city and county boundaries, ${ }^{287}$ the reapportionment revolution has meant that many of these political subdivisions can no longer remain intact within legislative districts.

In Connor v. Finch, ${ }^{288}$ for example, the Supreme Court considered a reapportionment plan drawn by a federal district court for Mississippi's legislature. The district court's plan followed state policy, which favored keeping county borders intact when drawing legislative districts, but contained significant population disparities. ${ }^{289}$ The Court, finding that the plan failed to satisfy Equal Protection standards, ${ }^{290}$ concluded that, given Mississippi's demographics and the number of legislative seats, "the inviolability of county lines ..., if strictly adhered to, must inevitably collide with the basic equal protection standard of one person, one vote. ${ }^{291}$

In many states, counties must be divided among more than one legislative district because the combination of demographics and the number of seats in the legislature precludes strict adherence to principles of both population equality and subdivision integrity. This tension is especially prevalent in states

285. The Court in Reynolds first recognized this tension, noting that "[c]arried too far, a scheme of giving at least one seat in one house to each political subdivision (for example, to each county) could easily result, in many States, in a total subversion of the equal-population principle in that legislative body." Id. at 581. See also White v. Regester, 412 U.S. 755, 764-65 n.8 (1973) (noting districting plan represented accommodation of competing interests of population equality and maintaining county boundaries). Commentators have also identified these competing factors. See, e.g., Dixon, supra note 283, at 30.

286. Chapman v. Meier, 420 U.S. 1 (1975); Kilgarlin v. Hill, 386 U.S. 120 (1967) (per curiam); Reynolds, 377 U.S. 533; Chavis v. Whitcomb, 305 F. Supp. 1364 (S.D. Ind. 1969) (three-judge court) (state policy against dividing counties conflicts with Equal Protection principles), rev'd on other grounds, 403 U.S. 124 (1971).

287. See, e.g., Brown v. Thomson, 462 U.S. 835 (1983) (upholding plan on narrow question of whether policy of preserving county boundaries justified small deviation with respect to single county); Mahan v. Howell, 410 U.S. 315, 329 (1973) (upholding plan but finding it "may approach tolerable limits" for population deviations); Abate v. Mundt, 403 U.S. 182 (1971) (upholding plan). In the context of congressional reapportionment, the argument that this consideration justifies deviations has routinely been rejected, see, e.g., White v. Weiser, 412 U.S. 783 (1973); Kirkpatrick v. Preisler, 394 U.S. 526 (1969), although minor deviations based on a policy of adhering to county boundaries may in some instances be justified, see Karcher v. Daggett, 462 U.S. 725, 733 n.5, 740-41 (1983) (describing relevant factors in this calculation).

288. 431 U.S. 407 (1977).

289. Id. at 416-17. The senate plan contained a maximum deviation from population equality of $16.5 \%$; the deviation in the house plan was 19.3\%. The district court followed two criteria in seeking to preserve county representation: (1) each county whose population equalled or exceeded the population norm was included in a single district, and (2) no remaining counties were divided into more than two districts unless those districts were located entirely within the county boundaries. Id. at 418 . The court plan became necessary after 12 years of litigation in which the Mississippi legislature refused to implement a constitutionally acceptable plan for its severely malapportioned legislative districts. Id. at 410 .

290. Id. at 420-21. The Court strongly hinted that the plan also was tainted by impermissible racial considerations, but did not specifically reach this claim. Id. at 421-26.

291. Id. at 419 . The Supreme Court recognized that the twin goals of population equality and county integrity could not be met in a state such as Mississippi where the population was unevenly distributed and many counties lacked sufficient people to elect a representative. Id. at 418-19. 
with a large number of political subdivisions and relatively few legislative seats, ${ }^{292}$ or in those whose population is unevenly distributed among political subdivisions throughout the state. ${ }^{293}$ Thus, although a fair districting plan will inevitably include whole counties and cities within some of its legislative districts, ${ }^{294}$ population equality almost always requires some fragmentation of cities and counties. Even those political subdivisions not fragmented are often submerged in larger legislative districts in which their residents constitute only a small percentage of the population. ${ }^{295}$

Under these circumstances, the members of the legislative delegation inevitably reflect, in varying degrees, the preferences of voters residing outside of the affected city or county. This phenomenon, as well as the opportunity to gerrymander legislative delegations, is the subject of the remainder of Part III.

\section{Delegation Gerrymanders}

Although legislative delegations resemble local legislatures, ${ }^{296}$ the voting constituency for the delegation often bears little resemblance to the voting constituency for other local governing bodies. While members of local legislatures are elected by the voters of their respective political subdivisions ${ }^{297}$ (city council members are elected by city residents and county commission members are elected by county residents), membership on local legislative delegations

292. As the Court noted with respect to Alabama's demographics, the use of counties as representative districts will likely result in one-person, one-vote violations in states "where the number of counties is large and many of them are sparsely populated, and the number of seats in the legislative body being apportioned does not significantly exceed the number of counties." Reynolds v. Sims, 377 U.S. 533, 581 (1964). See also Brown v. Thomson, 462 U.S. 835, 845 n.7 (1983) (comparing Wyoming Senate with Wyoming House of Representatives); Karcher v. Daggett, 462 U.S. 725, 733 n.5 (1983) (noting that New Jersey is divided into 567 municipalities). For a general discussion of the relationship between these factors and the oneperson, one-vote principle, see RICHARD L. MORRILL, POLITICAL REDISTRICTING AND GEOGRAPHIC THEORY 25-27 (1981).

293. See, e.g., Brown, 462 U.S. at 845 n.7; Karcher, 462 U.S. at 733 n.5; Reynolds, 377 U.S. at 581.

294. The principle of population equality does not always trump the goal of maintaining subdivision boundaries. Reynolds recognized that maintaining political subdivision lines and other natural or historical boundaries is a legitimate consideration in legislative districting, while unnecessary fragmentation of subdivision lines can evidence an impermissible racially motivated gerrymander. 377 U.S. at 578-79. State policy often favors keeping subdivisions intact in legislative reapportionments. See, e.g., COLO. CONST. art. 5, § 47; MASS. CONST. amend. art. CI, § 1; N.Y. ELECTION LAW § 4-100 (McKinney 1978).

295. My argument is not that political subdivision boundaries should always be respected; in fact, it is often necessary to break these boundaries in order to create districts capable of electing minority candidates. See BRUCE E. CAN, THE REAPPORTIONMENT PUZZLE 166-68 (1984); Paul S. Edwards \& Nelson W. Polsby, Introduction: The Judicial Regulation of Political Processes-In Praise of Multiple Criteria, 9 YALE L. \& POL'Y REV. 190, 202-03 (1991) (describing North Carolina congressional redistricting). Nonetheless, the frequency of fragmented and submerged counties may evidence discrimination in the composition of legislative delegations. See infra notes 300-02 and accompanying text.

296. See supra notes $34-42,66-76,268-69$ and accompanying text.

297. The methods for electing local legislatures vary widely. The two most common methods are atlarge election and election from single-member districts. James H. Svara, Unwrapping Instirutional Packages in Urban Government: the Combination of Election Institutions in American Cities, 39 J. POL. 166 (1977). There are numerous variations on these two basic methods of election, including plans that utilize a mixture of district and at-large components, multimember districts, majority vote requirements, numbered posts, and other electoral mechanisms. Blacksher \& Menefee, supra note 167, at 3 n.11. 
is in many cases determined by voters who live outside of the county governed by the delegation.

This incongruence between local legislative delegations and the voters who elect their members allows for the manipulation of delegation membership. Any legislator whose district includes any portion of the county will serve on the delegation for that county, and all voters in the district are eligible to vote for members of the delegation regardless of whether they actually reside in the county. As a result, because a reapportionment can incorporate noncounty voters in the delegation's constituency, electoral maneuvering can be used to discriminate against minorities in ways separate and apart from any discrimination in the legislative reapportionment.

The voting constituency for the delegation will include voters living outside of the county when the county is either submerged in a larger legislative district or fragmented between two or more districts. ${ }^{298}$ In both cases, ${ }^{299}$ the concern is twofold: (1) when can the voting strength of minority voters be diminished; and (2) when will the measures of dilution developed for state legislative reapportionments be inadequate with respect to delegation dilution?

A "delegation gerrymander" occurs when the legislative reapportionment satisfies prevailing voting rights standards, but the delegation reapportionment nonetheless impairs the voting strength of minority groups such as blacks and Hispanics. Of course, when a legislative reapportionment fails prevailing standards-by, say, blocking the election of minority-supported candidates to the legislature-it automatically discriminates against the legislative delegation because such a reapportionment plan also yields fewer minority-supported delegation members. Moreover, just as one offense causes the other, so the remedy for the first can repair the second: the remedy for the legislative gerrymander also cures the delegation gerrymander. However, legislative reapportionments that do not limit the number of minority-supported state legislators in a region can still discriminate with respect to the delegation by affecting the election districts for the delegation and its racial balance. These delegation gerrymanders can escape scrutiny under the Voting Rights Act unless their potential for discrimination is recognized.

The clearest potential for a delegation gerrymander arises when a county with a significant percentage of black voters adjoins counties in which white voters predominate, and when district lines are not congruent with county boundaries. ${ }^{300}$ When a county is split among more than one legislative district

298. Another variation of the split-county district is the split-city district, a large urban area that is included in legislative districts that cross city lines and include portions of the outlying suburban areas. Cain, supra note 25 , at $60-62$. Voters in the city are affected by a split-city district in much the same way as county voters are affected by a split-county district; in both cases, voters from outside of the relevant jurisdiction are given a vote on matters affecting the jurisdiction.

299. See supra notes $282-95$ and accompanying text.

300. The influence of the noncounty voters depends upon their relative numbers in the district compared to the numbers of county voters. The disparity between the influence of noncounty and county voters 
or is completely submerged in a single district, residents of adjoining counties can place their "representative" on the delegation. ${ }^{301}$ Minority voting strength can be diminished if the residents of these adjoining counties vote differently from the county residents. ${ }^{302}$

Given the focus of vote dilution litigation on electing candidates to formally constituted bodies, judicial decisions do not record the efforts of those who would curtail black voting power on legislative delegations by manipulating legislative district lines. ${ }^{303}$ Nonetheless, recent developments in reapportionment plans drawn after the 1990 census provide solid evidence that racial factors have led to deliberate delegation gerrymanders. Two delegation gerrymanders in reapportionment plans for the Georgia House of Representatives are cases in point. ${ }^{304}$ Early this year, the Justice Department found that dele-

becomes more acute as the county's population decreases as a percentage of the total population of the legislative district. The smaller the percentage of county residents in the district that splits or submerges the county, the less influence county residents have on the election of the legislator who sits as a member of their delegation. In fact, a representative may sit as a member of a county delegation even if his or her district includes no county voters. This situation arises when no one resides in the portion of the county included in his or her district.

301. The phenomena of delegation fragmentation and submergence can occur in one of two ways. Under one scenario, the county's black population is insufficient to constitute a majority in a legislative district and must be joined with residents from adjoining counties. Under the other scenario, the legislature has deliberately set out to minimize black voting strength by importing voters from adjoining counties. In both cases, discrimination can occur even where the legislative reapportionment does not discriminate against black voters.

302. This theory of dilution is premised on the same theory articulated in Thomburg v. Gingles, 478 U.S. 30 (1986): minority voters should have the same opportunity to elect representatives as white voters. Where white voters vote differently from minority voters, and the candidates that minority voters prefer are usually defeated, then discrimination can be inferred. This analysis thus assumes a factor that was critical in Gingles-the existence of racial bloc voting and the concommitant lack of influence of minority voters on the election of a legislator in a majority-white district. Although this concept of dilution follows Gingles, the standard articulated in Gingles does not provide an appropriate measure in this context. See infra notes 411-12 and accompanying text. Moreover, the requirement that minority voters be geographically compact is inapplicable because of the potentially open-ended size of the delegation's constituency.

303. As the discussion infra Part III(B) demonstrates, delegation gerrymanders are a subtle and complex phenomenon. These "gerrymanders" cannot be detected simply by analyzing the impact of the legislative districting plan on the state legislature. Typically, evidence of such a racially motivated gerrymanders can be found where district lines fragment the county, whereas gerrymanders that are discriminatory in effect may either fragment or submerge the county.

304. Although the Justice Department ultimately objected to two delegation gerrymanders in Georgia, a third potential gerrymander occured in Bibb County, where the record is less well developed. Approximately $42 \%$ of Bibb County residents are black. 1990 CENSUS OF POPULATION AND HOUSING, supra note 156, at 38 (Table 3). Although the 3-2 white majority on the delegation established by the 1991 reapportionment reflects the county's racial mix, Letter from Mark H. Cohen, Georgia Senior Assistant Attomey General, to Sheila K. Delaney, Voting Section, United States Department of Justice (Nov. 27, 1991) (on file with author) [hereinafter Cohen Letter] (State of Georgia Reapportionment Submissions--supplemental information, attachment B-1.10), there is evidence that the legislature went to unusual lengths to preserve this balance. Since Bibb County lost population during the last decade, compare 1990 CENSUS OF POPULATION AND Housing, supra note 156, at 38 (Table 3) with 1980 CENSUS OF POPULATION, supra note 156, at 11 (Table 14), the county was entitled to only four representatives under the new plan. Rather than drawing a plan for a four-person delegation where blacks and whites could share power, the legislature enlarged the delegation to five members by creating a thind majority-white district that cropped the county on its westem edge. Letter from Thomas E. Lawrence, Minority Whip, Georgia House of Representatives, to Nancy Sardison, Esq., Voting Section, Civil Rights Division, United States Department of Justice 4 (Dec. 16, 1991) [hereinafter Lawrence Letter] (State of Georgia Reapportionment Submissions-supplemental information). The Justice Department expressed concern about this action, which retained the three-two white majority 
gation gerrymanders occured in Dougherty and Richmond Counties, located in the two areas comprising Georgia's "black belt."305 The Dougherty County gerrymander was included in the Georgia legislature's first effort to reapportion itself following the recent census; even more striking is the fact that the Richmond County gerrymander was included in the second reapportionment designed to cure the defects of the first plan. ${ }^{306}$

Dougherty County is located in southwest Georgia. ${ }^{307}$ Its county seat is Albany, the fifth largest city in the state. ${ }^{308}$ Slightly more than half of Dougherty County residents are black. ${ }^{309}$ Both Dougherty County and Albany have a sordid history of racial discrimination which is vividly captured in the remarks of Representative John White, a black member of the Dougherty County delegation, on the floor of the Georgia House of Representatives, ${ }^{310}$ and in a variety of administrative and judicial decisions. ${ }^{311}$

that had existed under the post-1980 reapportionment. Id. Only four years earlier, the Department of Justice had objected to a boundary line change that removed a delegation member from the Bibb County delegation. See infra note 366 and accompanying text. Loval legislators were thus well aware that changes in district boundaries could expand or contract the delegation.

305. See Letter from John R. Dunne, Assistant Attorney General, Civil Rights Division, United States Department of Justice, to Mark H. Cohen, Georgia Senior Assistant Attorney General 4 (Jan. 21, 1992) (on file with author) [hereinafter First Georgia Objection Letter] (objecting to Dougherty County); Letter from John R. Dunne, Assistant Attorney General, Civil Rights Division, United States Department of Justice, to Mark H. Cohen, Georgia Senior Assistant Attorney General 2 (Mar. 20, 1992) (on file with author) [hereinafter Second Georgia Objection Letter] (objecting to Richmond County). In both of these Justice Department investigations, the delegation gerrymanders were only one of numerous objectionable changes occasioned by Georgia's reapportionment changes. The house plan was drafted four times before it was approved, while the senate and congressional maps each underwent three revisions. Rhonda Cook, Feds' Redistricting OK Sets Up Primaries, ATLANTA CONST., Apr. 13, 1992, at 1A. See infra notes 445-50 and accompanying text for a discussion of the Justice Department's role in reviewing reapportionment plans.

305. See Letter from Michael J. Bowers, Georgia Attomey General, to Gerald W. Jones, Chief, Voting Section, Civil Rights Division, United States Department of Justice 10-11 (Feb. 20, 1992) (on file with author) [hereinafter First Bowers Letter].

307. Dougherty County is one of nine contiguous counties in southwest Georgia which form a block of majority-black counties (Baker, Calhoun, Dougherty, Clay, Randolph, Terrell, Quitman, Stewart, and Webster Counties). Letter from Kathleen L. Wilde, Staff Counsel, Southern Regional Office, American Civil Liberties Union Foundation, to John R. Dunne, Assistant Attorney General, Civil Rights Division, United States Department of Justice 34 (Oct. 30, 1991) (on file with author) [hereinafter ACLU Comment Letter] (comment letter under section 5 of the Voting Rights Act).

308. 1990 CENSUS OF POPULATION AND HoUSING, supra note 156, at 215 (Table 16).

309. According to the 1990 census, $50.2 \%$ of Dougherty County's residents are black. 1990 CENsus OF POPULATION AND Housng, supra note 156, at 43 (Table 3).

310. See Debates of Georgia State House of Representatives, at 25a-25c (Aug. 23, 1991) (unpublished transcript on file with author) [hereinafter House Floor Transcript]. The floor debate concerned the reapportionment plan for the Georgia House of Representatives.

311. Much of this racial discrimination is catalogued in Paige v. Gray, 437 F. Supp. 137, 154-56 (M.D. Ga. 1977), in which blacks successfully sued the City of Albany under the Voting Rights Act to overturn the at-large system of voting for city council positions. In 1972, the Dougherty County school board implemented a policy prohibiting unpaid leaves of absence soon after a black candidate announced his intention to run for the Georgia House of Representatives. This policy was invalidated by the Supreme Court in Dougherty County Bd. of Educ. v. White, 439 U.S. 32 (1978), a significant section 5 case. Representative John White, a black legislator who vehemently opposed the house reapportionment, was the plaintiff in Dougherty. Since the passage of the Voting Rights Act, the Justice Department has objected to four voting changes in Albany and Dougherty County. United States Department of Justice, Civil Rights Division, Complete Listing of Objections Pursuant to Section 5 of the Voting Rights Act of 1965 (Sept. 30, 1991) (on file with author). A federal court found that the City of Albany has engaged in racially discriminatory 
Since 1982, Dougherty County has had two black and two white members on its legislative delegation. Between 1980 and 1990, however, Dougherty County lost residents so that its population is now only sufficient to justify three legislative districts-and three delegation members. ${ }^{312}$ In the 1991 reapportionment plan, ${ }^{313}$ however, Dougherty County includes four legislative districts - three of which are entirely included within the county's borders. Two of these districts are majority-black while the third has a white majority. ${ }^{314}$ A fourth majority-white district was drawn to shoot up like a finger into Dougherty County from Mitchell County, which adjoins Dougherty on its southern border. ${ }^{315}$ Of the 34,582 constituents who reside in this district, only 3500 live in Dougherty County. ${ }^{316}$ Figure 1 depicts the configuration of all four districts. A white incumbent currently resides in the "finger" district, adding a second white to the legislative delegation and thus preventing black control of the delegation.

hiring practices, Johnson v. City of Albany, 413 F. Supp. 782 (M.D. Ga. 1976), and its hiring practices have been supervised by the court for more than a decade. Mann v. City of Aibany, 687 F. Supp. 583, 584-85 (M.D. Ga. 1988) (discussing permanent injunction order issued in Johnson on Sept. 2, 1976), vacated, 883 F.2d 999 (11th Cir. 1989). at 4.

312. See ACLU Comment Letter, supra note 307, at 9; First Georgia Objection Letter, supra note 305,

313. The statistics conceming the post-1990 reapportionment are derived from the ACLU Comment Letter, supra note 307.

314. Districts 161 and 162 are majority-black, while district 163 contains a white majority. First Bowers Letter, supra note 306, at 10-11 (referring to attached House Exhibit No. 6, statistical data sheet for house districts).

315. Legislators alternatively refer to the Dougherty County portion of district 164 as a "finger" or a "sliver." See Remarks of Representative Young-Cummings, House Floor Transript, supra note 310, at 6; Remarks of Representative White, id. at 25a. In the floor debate, Representative Young-Cummings noted that the terms "finger or sliver" are the "nicer names that we've heard" for the plan. Id. at 6. The term "finger" is apt, both because of the physical resemblance to an actual finger, and as a metaphor for the insult to the black community afforded by the plan. Representative White captures this concept graphically in noting that "down in Dougherty there is a finger that goes that way on the map [gesturing up]," $i d$. at $25 \mathrm{~b}$, and that "it is not necessary to have that sliver, or what I call that finger, which goes in one direction," id. at $25 \mathrm{a}$.

316. The Dougherty County residents who reside in the finger district could be easily absorbed by districts 161 and 162 , the two majority-black districts, which are slightly underpopulated under the proposed plan. First Bowers Letter, supra note 306, at 8-9 (House Exhibit No. 6, showing population of district 161 $(34,467)$ and $162(34,211)$ less than that of ideal district $(35,990))$. 
FIGURE 1. Dougherty County, Georgia Delegation Gerrymander

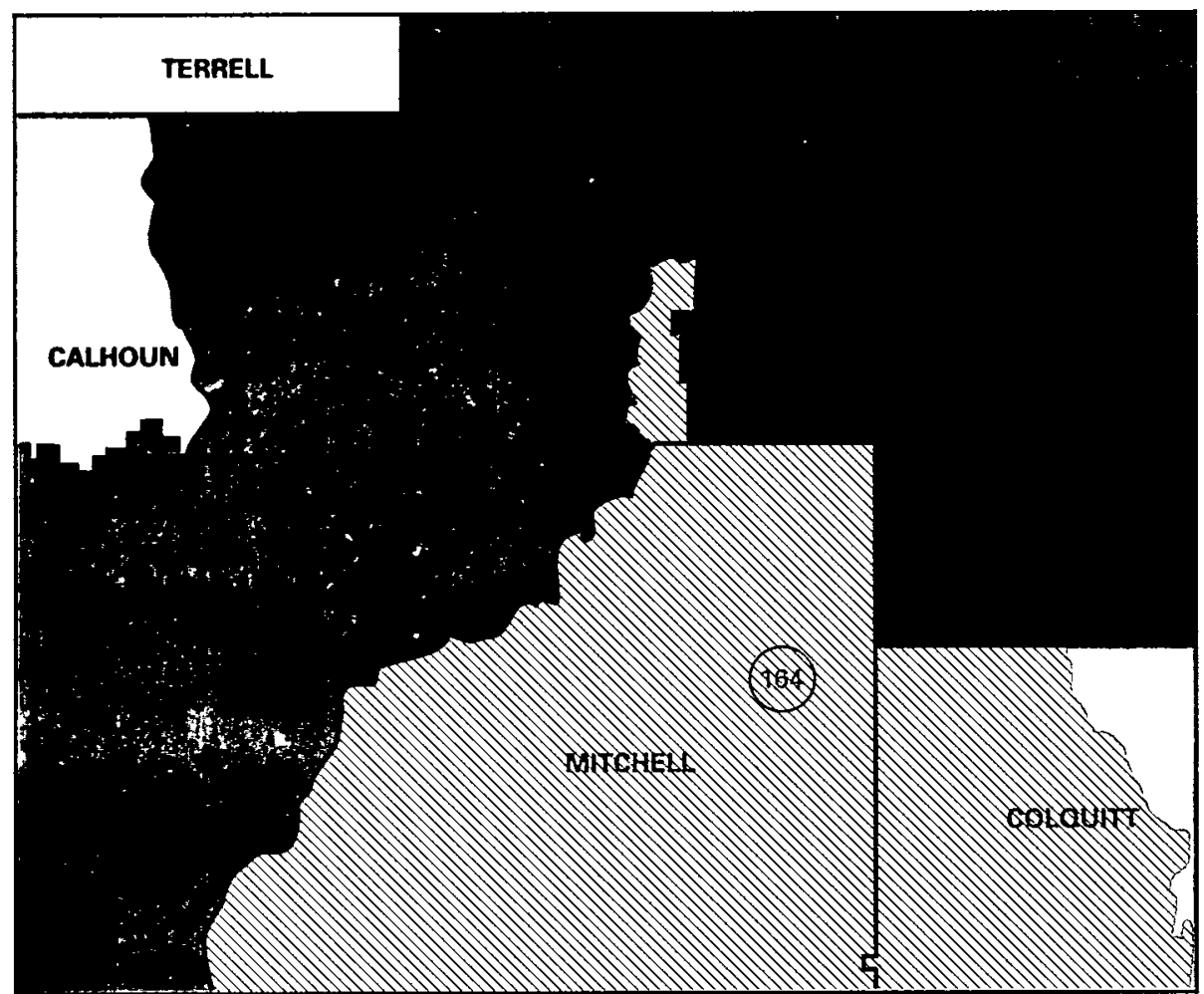

The reapportionment plan for Dougherty County, as initially drawn by a "work group" of legislators from Dougherty and surrounding counties, ${ }^{317}$ included only three districts, all of which were centered on the county ${ }^{318}$ The two black representatives from Dougherty County supported the work group's proposal. The recommendation was then submitted for approval to the house reapportionment committee, which added the finger district to the initial proposal..$^{319}$

The white community strongly supported the addition of a fourth member to the delegation while the black community vehemently opposed it. The local chamber of commerce and Representative Chambliss, a white member of the Dougherty County delegation, proposed the addition of the finger district, ostensibly because a fourth delegation member was necessary to retain Dougherty County's influence in the state legislature given the area's decrease in

317. The potential for discrimination in these "work group" procedures is discussed infra notes 496-500 and accompanying text.

318. ACLU Comment Letter, supra note 307 , at 8-9.

319. Id. at 9 . 
population during the last decade. ${ }^{320}$ Richard Royal, the representative whose district was reconfigured into the finger district, and who resides in Mitchell County, is a member of Albany's white business community and an influential member of the house. ${ }^{321}$

Black residents of Dougherty County and their representatives fiercely resisted the addition of the finger district. Black residents were especially outraged that the public hearings on the plan were held in Dawson, Georgia rather than in Albany, where most of the affected constituents resided. ${ }^{322}$ When Representative Young-Cummings offered an amendment on the house floor to remove the finger and reconfigure the remaining Dougherty County districts, all 27 black house members voted in favor of it. The amendment was defeated, however, by a vote of 129 to $44 . .^{323}$

The delegation's expansion to include a fourth white member, ${ }^{324}$ coupled with the prevailing practice of local courtesy, ${ }^{325}$ could neutralize black voting strength in Dougherty County because this new white legislator could vote with the other white member of the delegation to thwart the desires of black residents in Dougherty County. In the floor debate on the reapportionment plan, Mary Young-Cummings and John White, the two black representatives on the Dougherty County delegation, explained how the plan discriminated against blacks. According to Representative Young-Cummings, the plan would:

320. See id. at 9 (proffered reason for configuration was desire of white business community to maintain delegation size); Remarks of Representative Chambliss, House Floor Transcript, supra note 310, at 29 (stressing importance of delegation strength for local industrial development); Remarks of Representative Young-Cummings, House Floor Transcript, supra note 310, at 6 (describing business community's stated reasons). The proponents opposed other means of expanding the delegation, such as splitting the county into two senate districts. See Remarks of Representative White, House Floor Transcript, supra note 310, at 25a (Dougherty County business community opposed division of Albany senate district while requesting fourth house member for delegation). It is unlikely that a legislator whose district contains only a fraction of Dougherty County would be responsive to overall county interests in the state house. Where purely local matters are concerned, the size of the delegation is irrelevant to the success or failure of local legislation once it reaches the state legislature. The addition of a fourth member would only affect the outcome of internal delegation deliberations.

321. ACLU Comment Letter, supra note 307 , at 21.

322. Dawson, located in Terrell County, is the home of Representative Hanner, the chairperson of the house reapportionment committee. ACLU Comment Letter, supra note 307, at 22.

323. Remarks of Representative Young-Cummings, House Floor Transcript, supra note 310, at 49.

324. The proposed addition of a fourth member to the delegation implied that the three-member majority-black delegation could not adequately represent Dougherty County. As Representative YoungCummings asserted, "I am hurt by the fact that it would be assumed that the three of us could not address the needs of the business community who just happen to be by the way, very predominantly white." Id. at 6-7.

325. The exchange between Representative Hanner, the chairperson of the house reapportionment committee, and Representative Young-Cummings establishes the importance and viability of local courtesy:

134TH [Rep. Young-Cummings]: Mr. Speaker, is it not true that [substantive] issues are addressed by local legislation?

CHAIR: YES MA'AM, I THINK I COULD SAY THAT.

134TH: Is it not further true that local legislation, when properly passed by the members of the delegation under it's [sic] rules, are passed by this House as a matter of course without further deliberation?

CHAIR: THE LADY IS CORRECT.

Id. at $48-49$ (emphasis in original). 
bring a fourth person onto the Dougherty County delegation over whom there would be no political accounting because if you take 3,200 population and divide that in half for a voting age and then divide it again for regist[ration] and divide it again for turnout, that person would be almost immune to any kind of accountability for decisions made in local legislation. And while we do have a rule that we will not interfere, we do not get involved in other people's legislation if it's handled by the delegation, then it passes. And therein lies the crux of the matter. All key issues from consolidation to annexation to our school boards that are elected, on up or down, we would have this person on the delegation without justification on key issues. ${ }^{326}$

Representative White added that "[i]t is an unnecessary move, and what it does is dilute the decision-making of the two black members from Dougherty."327

In objecting to the Dougherty gerrymander, the Justice Department noted that "[c]oncerns were raised that the state's choices of boundary lines in this area were a response to requests that lines be drawn to avoid control by black voters' representatives by contriving to maintain an equal number of white and black legislators on the Dougherty County legislative delegation."328 The Justice Department commented on the "unusual configuration" of the fourth district, which the State "stretche[d] unnecessarily to retain four house districts based in [Dougherty] county," and noted that the State had not proffered a nonracial justification except the nebulous claim that the configuration was "drawn primarily due to specific requests." 329

A second delegation gerrymander occurred in Richmond County, Georgia, where the legislature drew a "land bridge" through Richmond County from neighboring Columbia and Jefferson Counties. ${ }^{330}$ The land bridge, pictured in Figure 2, clipped the western edge of Richmond County by stretching across Fort Gordon, an army base. ${ }^{331}$ Like the Dougherty County finger, the land bridge expanded the county delegation, increasing the size of the Richmond County house delegation from six to seven members, ${ }^{332}$ and in the process added a fourth white member to the delegation. ${ }^{333}$

326. Id. at 7 .

327. Id. at $25 \mathrm{~b}$.

328. First Georgia Objection Letter, supra note 305, at 4.

329. Id. After the Justice Department objection, the State replaced the objectionable plan with a fair plan. See First Bowers Letter, supra note 306, at 11 ("The House has acceded to the Justice Department's request by removing the so-called 'finger' into Dougherty County. ..."); Second Georgia Objection Letter, supra note 305 (identifying no objection to Dougherty County).

330. Second Georgia Objection Letter, supra note 305 , at 2.

331. Two Counties Sliced, AUGUSTA CHRON., Feb. 13, 1992, at 4A (editorial describing district as "gerrymandered").

332. James Salzer, New Black District Proposed, AugusTA CHRON., Feb. 11, 1992 at 1A, 3A [hereinafter Salzer, New District]; James Salzer, House Backs Remap Plan More Generous to Blacks; AuGUsTA CHRON., Feb. 12, 1992, at 1A.

333. Salzer, New District, supra note 332 , at $3 \mathrm{~A}$. 
FIGURE 2. Richmond County, Georgia Delegation Gerrymander

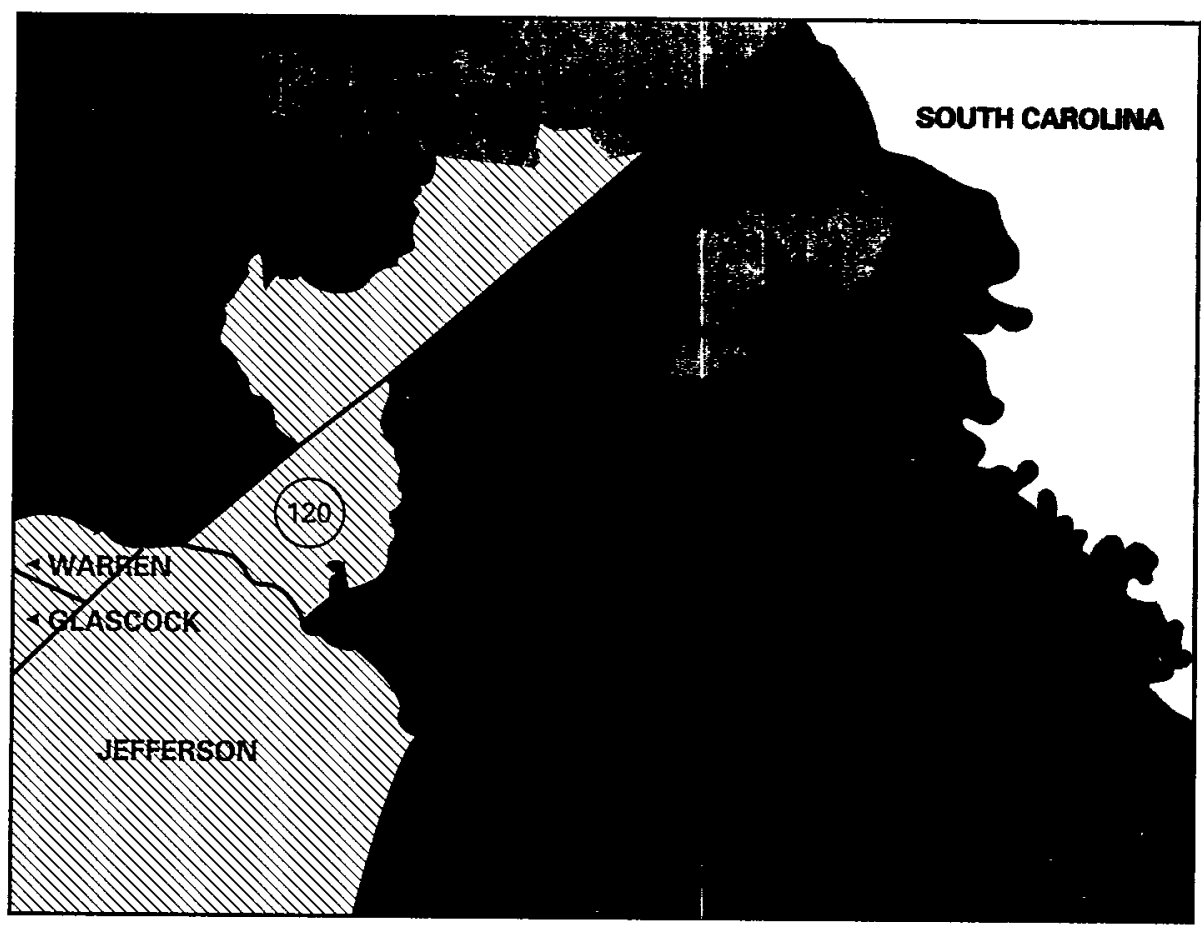

In its objection letter, the Justice Department expressed concern that the State's proposed configuration "was designed to maintain a white majority legislative delegation rather than have an equal number of white and black legislators on the Richmond County delegation."${ }^{.334}$ Moreover, the composition of the house delegation should not be viewed in isolation from the senate delegation. Since the election of Charles Walker in 1990, the two-member senate delegation has

334. Second Georgia Objection Letter, supra note 305, at 2. The State later enacted a fair plan to replace the objectionable plan. Letter from Michael J. Bowers, Georgia Attomey General, to Gerald W. Jones, Chief, Voting Section, Civil Rights Division, United States Department of Justice 3 (Mar. 25, 1992) (on file with author) [hereinafter Second Bowers Letter] (noting that state had removed objectionable aspect of Richmond County plan); Letter from John R. Dunne, Assistant Attorney General, Civil Rights Division, United States Department of Justice, to Mark H. Cohen, Georgia Senior Assistant Attorney General (Mar. 29, 1992) [hereinafter Third Georgia Objection Letter] (identifying no objection to Richmond County plan). The plan ultimately precleared by the Justice Department, see Letter from John R. Dunne, Assistant Attomey General, Civil Rights Division, United States Department of Justice, to Mark H. Cohen, Georgia Senior Assistant Attorney General (Apr. 2, 1992) (on file with author), created three majority-black districts (districts 116, 117, and 118) and three majority-white districts (districts 114, 115, 119). House Legislative Districts as Reflected in House Floor Substitute to S.B. 174 (March 30, 1992) (on file with author) [hereinafter 1992 House Reapportionment Statistics]. 
had only one black member. ${ }^{335}$ Thus, the land bridge enabled white residents to retain control not only of the house delegation, but also of the unified house and senate delegation.

Burke County, a rural county adjoining Richmond County in central east Georgia, illustrates another means by which a delegation districting plan can dilute the voting power of black residents. Although a slim majority of its inhabitants are black, ${ }^{336}$ this county has always had an all-white delegation ${ }^{337}$ Since the county's population is insufficient to sustain a senate district, Burke County must be combined with adjoining counties for senate elections. Moreover, county demographics prevent the formation of a viable minority house district within the county's borders. In fact, black voters did not have a real opportunity to elect a delegation reflecting the county's racial composition until Burke County was linked with Richmond County in the 1992 legislative reapportionment. ${ }^{338}$

The Burke County delegation has repeatedly frustrated black residents' efforts to attain political power. In the 1970's, for example, the local delegation refused to introduce legislation requiring members of the Burke County Commission to be elected from single-member districts. ${ }^{339}$ An even more glaring example of the delegation's refusal to relinquish control materialized during the controversy in the mid-1980's regarding the city of Keysville, a majority-black town of approximately 300 people $^{340}$ which is located 25 miles southwest of

335. See Linda Day, Walker's Victory 'Sweet', AUGUSTA CHRON., July 18, 1990, at IA (describing Walker victory in the primary). Walker ran unopposed in the general election.

336. According to the 1990 census, slightly over $52 \%$ of Burke County residents are black. 1990 CENSUS OF POPULATION AND Housing, supra note 156, at 38 (Table 3 ).

337. Bill English represents senate district 21, Members of the General Assembly of Georgia, Senate and House of Representatives, Second Session of 1991-1992 Term, at 4, 6 (on file with author), while John Godbee and Emory Bargeron represent house district 110 and house district 108, respectively. Id. at 34, 36-37. None of these legislators resides in Burke County.

338. In the elections to be held in the fall of 1992 after the new reapportionment, Burke County's legislators will be elected from senate district 22, Map of Senate Districts of Georgia (on file with author), and house districts 116 and 119, Map of Representative Districts of Georgia (on file with author). Burke County blacks may be able to elect black legislators from senate district 22 and house district 116 , both of which have black majorities in total population and in voting age population. 1992 Senate Reapportionment Statistics, as adopted March 24, 1992, at 2 (on file with author); 1992 House Reapportionment Statistics, supra note 334. Both districts make incursions into neighboring Richmond County to create black voting majorities. House district 116 was created only after the Justice Department objected to the legislature's first submission as "fragment[ing] the politically cohesive and active Burke County voters." First Georgia Objection Letter, supra note 305, at 3. See also First Bowers Letter, supra note 306, at 13-14 (new Burke County district drawn in response to objection). Neither of the two incumbents resides in this district. Id. at 14.

339. Rogers v. Lodge, 458 U.S. $613,625-27$ (1982). This was one of the factors that the Court cited in support of its conclusion that the at-large system had been maintained for racially discriminatory reasons. Id.

340. Effort to Restore Government in Georgia Town is Blocked, N.Y. TMMES, Dec. 31, 1987, at A17 [hereinafter Effort to Restore Government]. At the time, estimates of the percentage of Keysville's residents who are black ranged from $70 \%$, id., to $90 \%$, UPI, Aug. 15, 1987, available in LEXIS, Nexis Library, UPI File (untitled). According to the 1990 census, $78 \%$ of Keysville's residents are black. 1990 CENSUS OF POPULATION AND Housing, supra note 156 , at 38 (Table 3). 
Augusta in Burke County. ${ }^{341}$ When black residents petitioned their local delegation to support local legislation that would have established Keysville's boundaries, a prerequisite for holding municipal elections, the delegation refused to approve the legislation. ${ }^{342}$ Although elections had been held using temporary boundaries, legislative action was necessary to end white residents' challenges to these demarcations. The delegation's refusal to cooperate effectively stalled black residents' efforts at self-governance until 1991.

The story of black residents' efforts to revive local government in Keysville is a compelling tale of racial strife. Although Keysville was incorporated in the the nineteenth century, town government had lain dormant since 1933.343 In 1985 , controversy arose concerning the town's boundaries ${ }^{344}$ when local blacks attempted to revive local government to fill the void they endured in basic municipal services. ${ }^{345}$ A New York Times article described Keysville's horrific conditions in graphic terms:

State highway 88 , which meanders through part of town, is virtually the only paved surface. Sandy roads lined by scrub brush, rusty cars and barking dogs lead to the shacks and mobile homes where most of the people live. Some people have wells and septic tanks. Others haul water and have crude homemade cesspools. ${ }^{346}$

Black residents believed that an active city government might help them acquire needed services. ${ }^{347}$

An all-black slate of candidates for Mayor and City Council ran unopposed $^{348}$ and were sworn into office in January of 1986. But white residents

341. Lawyer Says Irregularities May Have Marred Keysville Vote, UPI, Jan. 6, 1988, available. in LEXIS, Nexis Library, UPI File [hereinafter Lawyer Says Irregularities].

342. Gresham v. Harris, 695 F. Supp. 1179, 1180 (N.D. Ga. 1988), aff $d$ sub nom. Poole v. Gresham, 110 S. Ct. 2556 (1990).

343. Keysville Blacks Eager to Get Government Rolling, UPI, Sept. 9, 1987, available in LEXIS, Nexis Library, UPI File [hereinafter Keysville Blacks Eager]. The Great Depression apparently contributed to the demise of Keysville's local government. David Corvette, Keysville's Long Sleep May End, ATLANTA CONST., April 12, 1987, at 1C.

344. The town's boundaries were based on the location of the Keysville Academy, an all-white school that had been demolished in a tomado in the 1890's. Effort to Restore Government, supra note 340; Judge, Backing Blacks' Case, Orders Vote in Georgia Town, N.Y. TMES, Jan. 1, 1988, at 37 [hereinafter Backing Blacks' Case]. Boundaries were set as a circle with a half-mile radius centering on the school. Town Holds First Vote in 55 Years, Elects 5 Blacks, L.A. TMME, Jan. 5, 1988, at 12 [hereinafter Town Holds First Vote]. Because the location of the school was disputed, white residents argued that the town's boundaries were different from those asserted by the black citizens' group supporting the revival of local government.

345. The effort to reactivate the government was sparked by a local grocery store owner's application to Burke County officials for a beer license. Effort to Restore Government, supra note 340 . County officials told the applicant they lacked authority to issue licenses to businesses located in incorporated towns. He therefore found himself unable to obtain a license from either the county or the nonexistent city government. Id.; Corvette, supra note 343 , at $7 \mathrm{C}$.

346. Effort to Restore Government, supra note 340.

347. Backing Blacks' Case, supra note 344.

348. Corvette, supra note 343; Effort to Restore Government, supra note 340 . White residents boycotted the contest, Candidates Qualify in Keysville, UPI, Dec. 5, 1987, available in LEXIS, Nexis Library, UPI File [hereinafter Candidates Qualify], and an election was unnecessary because the candidates ran unop- 
obtained an injunction prohibiting the black officeholders from performing their official duties, and presented the injunction to the newly elected government five hours after it assumed office. ${ }^{349}$

Black residents then sought local legislation that would firmly establish Keysville's boundaries and forestall further legal challenges, but the delegation consistently rebuffed these efforts. ${ }^{350}$ Undeterred, blacks took their cause to State officials and the United States Department of Justice. Later that year, the Georgia Attorney General approved a map delineating tentative boundaries for Keysville, ${ }^{351}$ and the Justice Department subsequently precleared both the boundaries and an election schedule. ${ }^{352}$ Emma Gresham, a black candidate for mayor, stated: "The concerned citizens of Keysville are not ordinary people, they are people who are Christians who believe that God is a God of justice and a God of love, and that because of that Keysville will be a town with sanitary sewage, fire protection and a Democratic government. ${ }^{, 353}$ With this victory in hand, black residents once again pushed forward to hold elections, ${ }^{354}$ and after a flurry of litigation, ${ }^{355}$ the long-awaited vote occurred. In the first election held in Keysville in 55 years, a black mayor, four black

posed. Corvette, supra note 343.

349. Effort to Restore Government, supra note 340.

350. Gresham v. Harris, 695 F. Supp. at 1180 (N.D. Ga. 1988), vacated 488 U.S. 978 (1988).

351. Backing Blacks' Case, supra note 344; Effort to Restore Government, supra note 340. The Attorney General considered two alternative maps which bore little similarity to one another. The map presented by black residents of Keysville resulted in a majority-black city whereas the proposal of the white residents made the city majority-white. The Attomey General adopted boundaries similar to those included in the black group's map, noting that "although the boundaries of Keysville are still inexact they "appear capable of being sufficiently fixed as to determine the electors of the town." Candidates Qualify, supra note 348 .

352. Gresham, 695 F.Supp. at 1181.

353. UPI, Aug. 15, 1987, available in LEXIS, Nexis Library, UPI File (untitled).

354. Keysville residents were divided along racial lines, with black residents supporting an independent town govemment, and white residents opposing it. Backing Blacks' Case, supra note 344; Keysville Blacks Eager, supra note 343 (describing Keysville as "racially divided, small east Georgia town"); Keysville to Hold First Election Since 1933, UPI, Dec. 25, 1987, available in LEXIS, Nexis Library, UPI File [hereinafter Keysville to Hold First Election] ("The lines drawn between black and white residents over efforts to reactivate city government in Keysville are clearer than the [city's] boundary lines. ....). Although white residents claimed that they opposed change because they feared higher taxes and preferred a simple country way of life, charges of racism were levied against them. Effort to Restore Government, supra note 340; Keysville to Hold First Election, supra ("It's degenerated into a racial confrontation.") (quoting Laughlin McDonald, Director, Southern Regional Office, American Civil Liberties Union).

355. A state court judge enjoined the election, ruling that the city's boundaries were unknown and that only a slight shift in the boundaries could disqualify voters and candidates. Poole v. Lodge, No. 85-V-414 (Burke County Superior Court, Dec. 30, 1987). See Backing Blacks' Case, supra note 344; Effort to Restore Government, supra note 340 . A federal court judge overturned the injunction, Gresham, 695 F. Supp. at 1179 (describing preliminary injunction), and the election proceeded as planned on January 4, 1988. Town Election is First Since '33, N.Y. TMES, Jan. 5, 1988, at B5 [hereinafter Town Election]. On the same date, a group of whites appealed the federal ruling. Town Holds First Vote, supra note 344 . Their lawyer charged that voting irregularities marred the election. Lawyer Says Irregularities, supra note 341. Finally, the federal court entered a permanent injunction prohibiting the defendants from implementing the voting changes included in the state court order until the Justice Department precleared those changes. Gresham, $695 \mathrm{~F}$. Supp, at 1184. 
city councilpersons, and one white city councilperson were elected to city government. ${ }^{356}$ The elections were monitored by the Justice Department. ${ }^{357}$

Black residents continued to press for local legislation to define the city's boundaries, ${ }^{358}$ but the delegation effectively stonewalled on this issue. It was not until 1991 that black residents were able to persuade the delegation to pass local legislation establishing the city lines. ${ }^{359}$

In Burke County, the decision to concentrate political power with the delegation, rather than with local government, minimized black voting power. After a lengthy battle, Burke County blacks obtained a method of election that enabled them to replace the all-white county commission with a majority-black local governing body ${ }^{360}$ Yet blacks would have fared better if delegation powers had been transferred to local government, where blacks have more political influence. This disparity demonstrates the dichotomy between two structures for managing local government: a delegation system that undercuts black voting strength and a truly local system that recognizes it.

In addition to delegation gerrymandering through reapportionment, evidence shows that delegations have also been used to limit the voting strength of black voters via annexation and the manipulation of city boundaries. The membership of legislative delegations can be altered not only by changing legislative district lines, but also by redefining the boundaries of political subdivisions. By expanding its boundaries across an existing legislative district line, a city can annex a portion of that legislative district and thereby add legislators to the city's delegation; in contrast, by contracting its boundaries so that the city includes fewer legislative districts within its borders, the city can remove legislators from its delegation.

356. Town Election, supra note 355; Town Holds First Vote, supra note 344. The black candidates were elected from what residents referred to as the "Emma Gresham slate," while the lone white councilperson was elected from the slate known as the "nursing home slate." Blacks Urging High Turnout in Keysville Election, UPI, Dec. 20, 1987, available in LEXIS, Nexis Library, UPI File. State Representative Tyrone Brooks accused the local nursing home of spearheading white opposition and of intimidating employees to oppose reactivating government. Id.; Candidates Go Door-to-Door Soliciting Votes, UPI, Dec. 19, 1987, available in LEXIS, Nexis Library, UPI File.

357. Town Election, supra note 355.

358. State officials repeatedly urged that local legislation was required to firmly establish Keysville's boundaries. Corvette, supra note 343 .

359. A 1987 effort to pass local legislation failed, Corvette, supra note 343, while a 1989 bill passed the senate, see Georgia S.B. 392 (1989) (act to provide new charter for City of Keysville), but failed to gain the support of Representative Bargeron in the house. Finally, black residents leveraged their election year clout to force Representative Bargeron to sign the legislation. Telephone Interview with Herman Lodge, Burke County Commission, and Laughlin McDonald, Director, Southern Regional Office, American Civil Liberties Union Foundation (Sept. 25, 1991) (memorandum summarizing conversations on file with author). S.B. 392 was endorsed by the delegation and unanimously approved by the Georgia Senate and House of Representatives. See Georgia S.B. 392 (1989).

360. The litigation against the Burke County Commission culminated in Rogers v. Lodge, 458 U.S. 613 (1982), in which the Court held that the at-large method of electing the county commission had been maintained with the intent to discriminate against black voters. After Rogers, the county adopted a district method of election, and now a majority of the county commission members are black. Corvette, supra note 343. 
A recently filed lawsuit, Blanton $v$. Campbell, ${ }^{361}$ challenges this type of annexation by Dorchester County, South Carolina. Plaintiffs allege that Dorchester County annexed 50 acres of uninhabited land, and in so doing, crossed over the boundaries of a state house district and a state senate district. This action increased the size of the delegation from 5 to 7 members. The additional state senator and state representative are white, and have therefore reduced the voting power of the lone black delegation member from one vote out of 5 to one vote out of 7.362

An annexation altered the composition of the Augusta, Georgia delegation in a similar fashion. As mentioned earlier, ${ }^{363}$ the city annexed two parcels of land that lay in legislative districts abutting the city limits in 1985, and in so doing added two white legislators to the previously half-black, half-white, delegation. ${ }^{364}$ Although the impact of this action on the delegation was never scrutinized, minority leaders alleged that the purpose was to diminish black political power. ${ }^{365}$

In 1984, the city of Macon, Georgia similarly decreased the size of its delegation by severing the entire portion of a legislative district that lay within city boundaries. The city was divided between Bibb County and Jones County, although only a tiny portion of the city was located in Jones County. The city asserted that by detaching the Jones County portion of Macon, it could remove the Jones County legislator from the Bibb and Macon delegations. This action demonstrates that local officials have been acutely aware of their ability to manipulate delegation membership. ${ }^{366}$

361. C.A. No. 2-91-3635-1 (D.S.C. filed Dec. 12, 1991).

362. Although the complaint does not cite specific instances of discrimination by the delegation, it alleges violations of section 2 of the Voting Rights Act, as well as a failure to satisfy the one-person, onevote principle. The plaintiffs seek a remedy pertaining not only to Dorchester County, but also to the general delegation system statewide. The remedy aspect of the case is further discussed infra Part II(D). At the present time, the court has not ruled on the merits of the case. In any event, the position of the delegation has changed as a consequence of the 1992 reapportionment. See Plaintiffs' Opposition to Motion to be Relieved as Counsel Until Substitute Counsel is Obtained, and Motion to Stay Proceedings, Blanton v. Campbell, No. 2-91-3635-1, at 1 (D.S.C. Sept. 17, 1992).

363. See supra notes $174-83$ and accompanying text.

364. Prior to the 1985 annexations, the city's boundaries included four districts. The four legislators elected from those districts sat as members of the city delegation. Since two of the delegation members were white and two were black, delegation deliberations on racial issues provoked controversy and deadlock. See supra Part I(C)(3).

365. See supra notes $176-82$.

366. The Justice Department found the alteration of municipal boundaries objectionable for reasons other than its impact on the delegation. See Letter from William Bradford Reynolds, Assistant Attomey General, Civil Rights Division, United States Department of Justice, to Roy W. Griffis, Assistant City Attorney, Macon, Georgia 2 (Apr. 24, 1987) (on file with author). The city claimed that the Jones County legislator was the target of the deannexation, id., and asserted the novel argument that it intended to remove him from the delegation because he was hostile to black interests. The Justice Department noted that "this [action] could have been accomplished through alternate and much less drastic means," $i d$., and found instead that the purpose was to remove the virtually all black portion of Jones county from the city limits. The detachment would have ousted black residents from a Macon city council ward in which a black candidate had narrowly won office in a recent election. See Letter from James M. Elliott, Jr., Macon City Attomey, to Mary Ann Jackman, Voting Section, Civil Rights Division, United States Department of Justice (Aug. 8, 1984) (election results attachment at 11) (on file with author). 
Moreover, there is every reason to believe that the type of discrimination against delegations revealed by the Georgia reapportionment and annexation cases is not uncommon. Delegations enjoy local power analogous to that possessed by formal local governing bodies. The history of discrimination against minority voters in the selection of local governing bodies is well documented ${ }^{367}$ thus, delegations have also likely been the focus of discriminatory reapportionments and annexations. Furthermore, two recent developments are likely to multiply the number of such gerrymanders by creating even stronger incentives to manipulate delegation membership.

First, the most obvious means of limiting minority voting power in state legislatures-the imposition of barriers to electing minority candidates-has become less available. Now that the Supreme Court's opinion in Gingles has clarified the standards governing discrimination in the election of state legislators, the case will serve as a powerful weapon to attack discriminatory reapportionments in the new census-related round of legislative redistricting. ${ }^{368}$ Following Gingles, many of these legislative districting schemes have encountered objections from the Justice Department. ${ }^{369}$ Because traditional modes of discrimination via legislative reapportionment have become less available, the focus of prejudice will likely shift to newer methods of discriminatory linedrawing.

Second, the threat of minorities gaining influence or control of delegations has become real as minority candidates are elected to state legislatures in everincreasing numbers. ${ }^{370}$ In fact, minority legislators are a significant presence on many legislative delegations, ${ }^{371}$ although they still constitute only a frac-

367. See, e.g., City of Mobile v. Bolden, 446 U.S. 55 (1980) (at-large election of city commissioners has effect of diluting minority vote); Garza v. County of Los Angeles, 918 F.2d 763 (9th Cir. 1990) (districting for county board of supervisors discriminatory), cert. denied, 111 S. Ct. 681 (1991); Ketchum v. Byrne, 740 F.2d 1398 (7th Cir. 1985) (districting for city council discriminatory), cert. denied sub. nom. City Council of Chicago v. Ketchum, 471 U.S. 1135 (1985); Kirksey v. Board of Supervisors, 554 F.2d 139 (5th Cir. 1977) (redistricting plan for county board of supervisors discriminatory).

368. Thornburg v. Gingles, 478 U.S. 30 (1986). See Jeffers v. Clinton, 730 F. Supp. 196, 202 (E.D. Ark. 1989) (three-judge court) (only with Gingles can law be said to have jelled), aff d, $111 \mathrm{~S}$. Ct. 662 (1991). Because Gingles was decided after the legality of most post-1980 reapportionments had been decided, it affected only a few of these reapportionments. See, e.g., Armour v. State of Ohio, 775 F. Supp. 1044, 1050 (N.D. Ohio 1991) (three-judge court) (applying modified Gingles test); Jeffers, 730 F. Supp. at 205 (applying Gingles to 1981 reapportionment of Arkansas legislature).

369. The Department of Justice objected to redistrictings in Mississippi, Louisiana, Virginia, and Georgia. Robert Pear, Under the Voting Law, Citizens' Rights Get More Than Lip Service, N.Y. TMIES, July 21, 1991, at D4; Gary Taylor, Vote Storms Ahead, NAT'L L.J., Nov. 4, 1991, at 1. The Justice Department has been justly criticized for weak enforcement of voting rights during the 1980's, NORMAN C. AMiAKER, CIVIL RIGHTS \& THE REAGAN ADMINISTRATION 153 (1988); Lani Guinier, Keeping the Faith: Black Voters in the Post-Reagan Era, 24 HARV. C.R.-C.L. L. REv. 393, 399-414 (1989) (reviewing Reagan Administration's voting rights record), although its enforcement efforts have been revitalized during the past few years. See Pear, supra; Taylor, supra.

370. McDonald, supra note 13, at 1252; Thomas B. Edsall, GOP Goal: Gain Ground by Fostering 'Majority Minority' Districts, WASH. POST, July 7, 1990, at A6.

371. See, e.g., Edsall, supra note 370 (describing Columbia County, South Carolina and Jefferson County, Alabama delegations); McNeil, supra note 268 (describing Greene County, Alabama delegation as all-black delegation); supra note 153-54 and accompanying text (describing Richmond County (Augusta), 
tion of those elected to the legislature in any state. Moreover, because of partisan alliances, the effect of the changing racial composition of legislative delegations in the South has been amplified. In many instances, Republican gains have paralleled the increase in the number of blacks serving on legislative delegations, ${ }^{372}$ while both of these changes have derived in large part from the switch from multimember to single-member districts. ${ }^{373}$ Thus, black Democrats and white Republicans are at the epicenter of a struggle for power on delegations no longer dominated by white Democrats. ${ }^{374}$

In this changing political landscape, delegation members often represent a diverse spectrum of interests. ${ }^{375}$ The deliberations of many delegations have become increasingly divisive as voting patterns polarized along race and party lines. ${ }^{376}$ On many delegations, even minor changes in delegation membership could shift the balance of political control. ${ }^{377}$ The delegation from Jefferson County, Alabama provides a striking example of a delegation divided along

\section{Georgia delegation).}

372. See Keith E. Hamm et al., Ethnic and Partisan Minorities in Two Southern State Legislatures, 8 LEGIS. STUD. Q. 177, 177 (1983) [hereinafter, Hamm et al., Ethnic \& Partisan Minorities]; Keith E. Hamm et al., Impacts of Districting Change on Voting Cohesion and Representation, 43 J. POL. 544, 546 (1981) [hereinafter Hamm et al., Voting Cohesion] (describing delegations in Texas and South Carolina). Although Republicans are a minority in every Southem legislature, Edsall, supra note 42 (noting that Republicans have controlled only one Southem legislature (Tennessee) in the past 100 years), they are often a significant presence on legislative delegations. See, e.g., Edsall, supra note 370 (describing Columbia County, South Carolina and Jefferson County, Alabama delegations); Edsall, supra note 42, at A6 (describing delegations in 15 South Carolina counties as evenly split between Democrats and Republicans).

373. JACK BASS \& WALTER DEVRIES, THE TRANSFORMATION OF SOUTHERN POLIICS: SOCLAL CHANGE aNd POLITICAL CONSEQUENCE SINCE 1945 13-15 (1976); Hamm, et al, Voting Cohesion, supra note 372, at 545; Edsall, supra note 370, at A6 (describing minorities' increased political leverage as a result of post1980's redistrictings). Ironically, the change touted as the vehicle for increased representation for racial minorities has resulted in a greater number of "white" and Republican-dominated districts. See Guinier, supra note 29, at $1464 \mathrm{n} .188$ ("unholy alliance" between Republicans and minorities results in Republican districts with white majorities); Jack Quinn et al., Redrawing Political Maps: An America of Groups?, WASH. POST, March 24,1991, at Cl, C4. Not surprisingly, black Democrats are being elected from majorityblack districts, McDonald, supra note 13, at 1282-83 (citations omitted), and white Republicans are being elected from majority-white districts. Edsall, supra note 370 .

374. Race and party are closely correlated as blacks have gained political strength in the Democratic party and white Democrats have defected to the Republican party. See, e.g., Edsail, supra note 370; Edsall, supra note 42 (describing memorandum circulated by Alabama Democratic party entitled "Alabama's Democratic Agenda; Making 1989 The 'Year of the White Male."').

375. See Dauer, supra note 20, at 623-25; Brett Hawkins \& Cheryl Whelchel, Reapportionment and Urban Representation in Legislative Influence Positions: The Case of Georgia, URB. AFF. Q., Mar. 1968, at 69 (suggesting that Georgia reapportionment may result in diverse, more proportional representation). During the period dominated by multimember district elections, delegation members were elected by countywide constituencies and served nearly identical interests.

376. Hamm et al., Voting Cohesion, supra note 372, at 554-55; Edsall, supra note 42, at A6.

377. I do not suggest that political actors only have an incentive to play racial politics when election outcomes or control of an elected body are at stake. Voting cases document numerous instances in which the white power structure took steps to bar minority voters' access to the political process even when whites were guaranteed to remain in control of local politics. See, e.g., Garza v. County of Los Angeles, 918 F.2d 763 (9th Cir. 1990) (upholding district court's finding of discrimination even though no "majority-minority" district could have been drawn when the districting plan was drafted), cert. denied, $111 \mathrm{~S}$. Ct. 681 (1991); Paige v. Gray, 538 F.2d 1108, 1109 (Sth Cir. 1976) (white legislators took steps to guard against black control of single city ward). Nonetheless, political machinations are more likely to follow when control is at issue. 
racial and partisan lines. Jefferson County includes the city of Birmingham, Alabama's largest city, and its surrounding suburbs. ${ }^{378}$ The eighteen-member delegation includes eight black Democrats, one white Democrat and nine white Republicans. ${ }^{379}$ Delegation deliberations are extremely divisive, with members of the delegation voting along race and party lines. ${ }^{380}$ In this situation, and in others like it, the incentives to tinker with delegation membership are strong.

\section{B. Measuring Dilution}

As has been demonstrated, the method of selecting delegations can diminish the voting power of minority voters. What standard can be used to assess this diminution of voting strength? The standards for measuring racial vote dilu$\operatorname{tion}^{381}$ in the selection of representatives for other governing bodies provide a starting point for analysis. ${ }^{382}$

\section{Traditional Measures}

The essence of a racial vote dilution or racial gerrymander claim ${ }^{383}$ is that

378. Birmingham has made headlines with reports of racial tensions. See, e.g., Edsall, supra note 42, at A6 (alleged targeting of black elected officials for selective prosecution).

379. Edsall, supra note 42 , at A6.

380. Edsall, supra note 370, at A6; Edsall, supra note 42, at A6 (delegation adopted a single-member district plan for Birmingham to ensure that white voters in the majority-black city would elect some council members). In 1981, the Birmingham-Jefferson County bus system shut down when a divided legislative delegation failed to agree on a funding proposal. UPI, Feb. 26, 1981, available in LEXIS, Nexis Library, UPI File (untitled).

381. The racial vote dilution cases represent only one type of vote dilution litigation; the other strands are the one-person, one-vote cases and the political vote dilution cases. See supra note 214 . The standards for measuring racial vote dilution, however, differ from those used in these other areas. The one-person, one-vote cases have a quantitative focus. See Karlan, supra note 196, at 176. Plaintiffs face a higher standard of proof for political gerrymander claims than for racial gerrymander claims, see Davis v. Bandemer, 478 U.S. 109, 132 (1986) ("[U]nconstitutional discrimination occurs only when the electoral system is arranged in a manner that will consistently degrade a voter's or a group of voters' influence on the political process as a whole."). The other strands of dilution theory are nonetheless instructive because they explain how political influence can be manipulated by the drawing of district lines.

382. The measure of dilution is relevant even where the delegation reapportionment is claimed to be purposefully discriminatory, but is especially critical where the reapportionment is claimed simply to have a discriminatory effect. Compare Pleasant Grove v. United States, 479 U.S. 462, 471-72 (1987) (explaining impermissible effect of annexations found purposefully discriminatory) with City of Richmond v. United States, 422 U.S. 358, 378 (1975) (relevant comparison of effects is between "the relative political strength of the minority race in the enlarged city as compared with what it was before the annexation").

383. Because discriminatory line-drawing is alternatively described as vote dilution or a racial gerrymander, see Parker, supra note 208, at 106-08, I use the terms interchangeably in discussing the impact of districting lines on delegations. The claim that district lines are racially gerrymandered has arisen in the context of multimember districts, see, e.g., Rogers v. Lodge, 458 U.S. 613 (1982); City of Mobile v. Bolden, 446 U.S. 55 (1980); White v. Regester, 412 U.S. 755 (1973), and single-member districts, see United Jewish Orgs. v. Carey, 430 U.S. 144 (1977); Wright v. Rockefeller, 376 U.S. 52 (1964). Although the term gerrymander typically encompasses the alteration of district lines, other lines can be manipulated to disadvantage minority voters as well. Claims that municipal boundaries have been altered to discriminate against minority voters, either through annexation, see Gomillion v. Lightfoot, 364 U.S. 339 (1960), or consolidation are also properly considered gerrymander claims because these lines, like legislative districting lines, determine the constituency for elections. See Parker, supra note 208, at 86-87. Vote dilution includes 
a fairer districting plan would give minority voters a better opportunity to elect candidates of their choice. ${ }^{384}$ There are two critical components to this inquiry: first, the definition of an elected office; and second, the measure of dilution used. $^{385}$

Although the vote dilution inquiry is triggered once an office is designated elective, ${ }^{386}$ a precise definition of an elected office has not emerged from voting rights cases. When a candidate files for a designated office, has his or her name placed on the ballot as a candidate, and receives votes on election day for that position, there is little doubt that the office sought is an elected office. ${ }^{387}$ The facts in these cases have not given rise to any ambiguity about whether the office is an elected one. ${ }^{388}$

With respect to the measure of dilution, the racial vote dilution cases fall into two broad categories: challenges to electoral structures that submerge minority voters in multimember districts, ${ }^{389}$ and challenges to electoral structures that fragment minority voters between districts. ${ }^{390}$ Thornburg $v$. Gingles

not only the drawing of district lines, but a broad range of other mechanisms for discrimination. See supra note 194.

384. Guinier, supra note 29 , at 1415 (describing view of traditional voting rights advocates).

385. As promised in the introduction, the analysis in this Section does not depend on distinctions between section 2 and section 5 of the Act. Because section 5 is limited geographically and requires some change in the status quo, see supra note 30 and accompanying text, section 2 comes into play more often than section 5. On the other hand, once litigants have met the threshhold requirements of section 5 (challenging a voting change in a covered jurisdiction), they are more likely to prevail because the burden of proof is on the entity seeking to implement the voting practice. Nonetheless, the general contours of dilution do not differ significantly under the two sections.

386. Although section 5 applies to appointed offices in the sense that it governs the substantive decision as to whether an office is made elective or appointive, see Presley v. Etowah County Comm'n, $112 \mathrm{~S}$. Ct. $820,828,832$ (1992), section 2 applies only to elective offices. See Irby v. Virginia State Bd. of Elections, 889 F.2d 1352, 1357 (4th Cir. 1989) ("II]t appears more probable than not that section 2 is not applicable to appointive offices."), cert. denied, 496 U.S. 906 (1990). However, a district court in Alabama has held that section 2 applies to the appointment of poll and registration officials. Harris v. Graddick, 601 F. Supp. 70 (M.D. Ala. 1984) (denying motion to dissolve injunction); Harris v. Graddick, 615 F. Supp. 239 (M.D. Ala. 1985) (granting motion to approve settlement).

387. In fact, the question of whether an office is elected is not always straightforward. The classic example is Sailors v. Board of Educ., 387 U.S. 105 (1967), in which the Court discussed the applicability of the one-person, one-vote standard to the selection of a county school board. Members of local school boards were elected from districts of varying size, and in turn selected delegates from among their members to choose the members of the county school board. The Court concluded that the process was "basically appointive rather than elective," $i d$. at 109 , because school board members were not "determined, directly or indirectly, through an election in which the residents of the county participate." Id. at 110 n.6.

388. For example, the elective status of the legislative seats at issue in Thornburg v. Gingles, 478 U.S. 30 (1986), or the judgeships in Chisom v. Roemer, 111 S. Ct. 2354 (1991), was not in dispute. From another perspective, the North Carolina legislators occupied more than one legislative office. They wore at least two hats: that of representative to the state legislature, and that of representative on their respective legislative delegations.

389. For a general discussion of these cases, see supra notes 214-44 and accompanying text. In a multimember district, voters elect more than one representative. At-large electoral structures are thus the ultimate multimember district: all of the representatives for the jurisdiction are elected from one district. See supra note 226.

390. Garza v. County of Los Angeles, 918 F.2d 763 (9th Cir. 1990), cert. denied, 11 I S. Ct. 681 (1991); Kirksey v. Board of Supervisors, 554 F.2d 139 (5th Cir. 1977). Plaintiffs with submergence claims typically allege that there are too few districts, while plaintiffs with fragmentation claims assert that while the number of districts is sufficient, minority voters are divided among the districts in a way that diminishes 
articulates the liability standard for vote dilution caused by the submergence of black voters in multimember districts. There, the Court held that "unless there is a conjunction of the following circumstances, the use of multimember districts generally will not impede the ability of minority voters to elect representatives of their choice. Stated succinctly, a bloc voting majority must usually be able to defeat candidates supported by a politically cohesive, geographically insular minority group."391

Although the concepts of racial bloc voting, geographic insularity, and political cohesiveness are complex, the Gingles test in its simplest form is quite straightforward: if candidates supported by minority voters enjoyed little success under the existing system even though minority voters potentially could elect candidates from single-member districts, then multimember districts are dilutive. Under the Court's analysis, dilution stems from the decision to draw an insufficient number of districts, coupled with white voters' refusal to support black candidates. Thus, dilution is only legally significant when the outcome would be different under an alternative system.

With respect to the second type of vote dilution claim-that a districting plan fragments minority voters-Gingles offers little explicit guidance..$^{392}$ Presumptively, the Gingles test is as analytically sound for a fragmentation case as it is for a submergence case. ${ }^{393}$ In both types of cases, dilution occurs

their ability to elect candidates. In this respect, the fragmentation cases bear a close resemblance to two other types of racial gerrymanders: packing and stacking cases. Parker, supra note 208, at 87. Packing refers to placing large concentrations of minority voters in one district so that they cannot achieve voting majorities in adjoining districts. Id. at 96-99. Stacking refers to the placing of a large minority population into a district with a larger white population in order to create a white majority district and eliminate a majority-minority district. Id. at 92-96.

391. 478 U.S. 30, $48-49$ (1986) (footnote omitted). The Court defined a geographically insular minority group as one that is "sufficiently large and geographically compact to constitute a majority in a singlemember district." Id. at 50 . The court also observed that "showing that a significant number of minority group members usually vote for the same candidates is one way of proving the political cohesiveness necessary to a vote dilution claim." Id. at 56. The concept of political cohesiveness is further explored in Butler \& Murray, supra note 15.

392. See supra note 241 . The court noted that it had "no occasion to consider" whether its standards "are fully pertinent to other sorts of vote dilution claims, such as a claim alleging that the splitting of a large and geographically cohesive minority between two or more multimember or single-member districts resulted in the dilution of the minority vote." Gingles, 478 U.S. at 47 n.12.

393. Frank R. Parker et al., Section 2 Litigation After Thomburg v. Gingles 64 (1990) (unpublished manuscript on file with author). Several courts have applied the Gingles test to redistrictings that fragment minority voters. See, e.g., Garza v. County of Los Angeles, 756 F. Supp. 1298, 1303-04, 1343-48 (C.D. CaI. 1990), aff d on other grounds, 918 F.2d 763 (9th Cir. 1990), cert. denied, 111 S. Ct. 681 (1991); Armour v. Ohio, 775 F. Supp. 1090 (applying Gingles as modified); Jeffers v. Clinton, 730 F. Supp. at 202, aff d, 111 S. Ct. 662 (1991). Cf. East Jefferson Coalition v. Jefferson Parish, 691 F. Supp. 991 (E.D. La. 1988) (applying Gingles test to remedial phase of litigation to determine appropriateness of districting plan that included some single-member districts). Some commentators have argued that the factors identified in section 2's legislative history bear little relevance to racial gerrymander cases. See Shapiro, supra note 279, at 198. Gingles, however, placed a significant "gloss" on the factors listed in SENATE REPORT, supra note 217 , by placing primary emphasis on one factor, racial bloc voting, and adding another factor, geographic compactness, that is not mentioned in the report. See City of Carrollton Branch of NAACP v. Stallings, 829 F.2d 1547, 1549-51 (11th Cir. 1987), cert. denied sub nom. Duncan v. City of Carroliton, Ga. Branch of NAACP, 485 U.S. 936 (1988); see also Karlan, supra note 196, at 177-79. The Gingles factors seem equally applicable to vote dilution and racial gerrymander claims. 
because white voters, as a numerical majority, are able to defeat the candidate choices of black voters. ${ }^{394}$

\section{Applying Traditional Measures to Delegations}

In applying the principles of racial vote dilution cases to legislative delegations, we must first determine whether legislative delegations can be considered to be elected bodies. Typically, an elected office is listed on a ballot and filled by the candidate receiving the most votes. By contrast, an appointed office is filled at the discretion of the appointing authority. Legislative delegations do not fit neatly into either category. An individual does not run for an office called "legislative delegate;" instead, individuals run for state legislative seats and, if elected, serve as members of the legislature as a whole and, thus, of the delegation. Nor is the office appointed in the sense that some public official or group of officials determines who sits on a delegation. ${ }^{395}$ Legislators become members of their respective delegations automatically upon election to the state legislature.

Because vote dilution cases provide little guidance on whether this unconventional arrangement fits the definition of an elected office, ${ }^{396}$ standards must be found elsewhere. Courts have grappled with the definition of an elected body in deciding whether the composition of certain public bodies violates the principle of one-person, one-vote. ${ }^{397}$ In Board of Estimate v. Morris, ${ }^{398}$ the Supreme Court applied the one-person, one-vote principle to the Board of Estimate of the City of New York. The members of the board, which consisted of the mayor, the president of the city council, the city comptroller, and the presidents of the five boroughs, had been elected to their respective city or

394. Evidence of racial bloc voting is especially critical because the placement of district lines will only curtail the influence of minority voters if black and white voters support different candidates. For an analysis of the relevance of racial bloc voting to racial gerrymander cases, see Shapiro, supra note 279, at 199-200. Moreover, the means of accomplishing the dilution are identical: white voters vote as a bloc and the voting district lines create districts in which black voters are outnumbered by white voters. In both cases, the votes of the minority group would have a greater impact where these voters vote as a bloc and district lines aggregated larger concentrations of minority voters.

395. See supra notes $37-42$ and accompanying text.

396. See supra notes $386-88$ and accompanying text.

397. The Equal Protection mandate applies when officials are selected by popular election and when those officials perform "governmental functions." See, e.g., Hadley v. Junior College Dist., 397 U.S. 50 (1970). Compared to the "governmental function" component of the one-person, one-vote inquiry, the "elective" component has received little attention. The meaning of a "governmental function" has been explored in numerous decisions, see, e.g., Ball v. James, 451 U.S. 355 (1981); Salyer Land Co. v. Tulare Lake Basin Water Storage Dist, 410 U.S. 719 (1973); Hadley, 397 U.S. 50; Avery v. Midland County, 390 U.S. 474 (1968), while cases discussing the elective/appointive distinction are relatively scarce. But see Sailors v. Board of Educ., 387 U.S. 105 (1967).

398. 489 U.S. 688 (1989). 
borough offices and served on the board by virtue of their election to these positions. ${ }^{399}$

In the court of appeals, the board argued that its members were not selected by popular election because they served ex officio, and no separate election was held for the board position. ${ }^{400}$ The court rejected this contention and concluded that the members of the board "are directly elected by the voters. Upon election to their respective positions, they automatically become Board members as a matter of law." ${ }^{\prime 401}$ The Supreme Court adopted this reasoning, noting that the selection of the members "trigger[ed] th[e] constitutional safeguard [of one person one-vote] [because] [a]ll eight officials become members as a matter of law upon their various elections., 402

This concept of an elected body is a functional one that rests on the relationship between the election and any intervening mechanism for selecting members of the body. The Court in Board of Estimate attributed no significance to the absence of a separate election or the lack of any formal description of the contested office on the ballot. The election was functionally an election for two offices because popular vote determined both the winners in the election and the membership of the board. ${ }^{403}$ Successful candidates were in effect representatives in a dual capacity, both that of city official and board member. ${ }^{404}$

Under the Board of Estimate analysis, legislative delegations should be viewed as elective bodies and state legislators as dual officeholders. Only those individuals who are elected to the state legislature from a particular county serve as members of the delegation. ${ }^{405}$.It is their election by the voters that places them on the delegation, just as it is their election to the state legislature that makes them members of the state legislature as a whole. County boundaries determine which elected officials sit as members of each delegation, and the selection of delegation members is automatic upon winning election to the state

399. The presidents of the five boroughs were elected from districts having widely varying populations; the remaining three officials were elected at-large. $I d$. at 690 .

400. Morris v. Board of Estimate, 707 F.2d 686, 688 (2d Cir. 1983), aff d, 489 U.S. 688 (1989).

401. Id. at 689. Section 61 of the New York City Charter provided: "The mayor, the comptroller, the president of the council and the presidents of the boroughs shall constitute the board of estimate." Id.

402. Board of Estimate, 489 U.S. at 694. This is the only part of the opinion to address the fact that the Board is an elective rather than an appointive body. The remainder of the opinion addresses the functions performed by the Board, and the relevance that the presence of at-large members on the Board had to calculations of population deviations. The Court found that shared legislative powers and exclusive nonlegislative powers were sufficient to require compliance with equal protection principles. Id. at 694-96.

403. As the court of appeals noted, "a citizen entering the voting booth in New York City "chooses at one and the same time' his Borough President and his Board of Estimate member." 707 F.2d at 689.

404. This characterization of certain offices as dual in nature can be found in other one-person, one-vote cases. See, e.g., Bianchi v. Griffing, 393 F.2d 457 (2d Cir. 1968) (elected town supervisors serve as town supervisors and county board members).

405. See supra notes $37-42$ and accompanying text. 
legislature. ${ }^{406}$ This election fills two offices, that of state legislator and that of local delegation member.

Once delegations are seen as elective bodies, then the method by which they are elected merits examination—any other elected body-to determine whether minority voters have an equal opportunity to elect representatives to the delegation. Gingles ${ }^{407}$ teaches that geographically compact groups of minority voters submerged in large multimember districts suffer vote dilution where white voters usually vote as a bloc to defeat candidates supported by politically cohesive minority voters. ${ }^{408}$ However, under some circumstances, the Gingles test cannot capture dilution in the context of legislative delegations.

Take, for example, the case of hypothetical County $A$, whose population is more than sufficient to entitle it to two legislative seats but not large enough to entitle it to three. ${ }^{409}$ Fifty percent of the population is black and the remainder is white. County residents vote along racial lines. The county's black residents are concentrated in the county in such a way that they could constitute a majority of the population in a single legislative district. The counties surrounding County $A$ are predominantly white and no majority-black district could be drawn in this area.

Three primary options exist for drawing legislative districts in County $A$ : the legislature could draw one multimember district with two seats; two singlemember districts that divide black voters between the districts; or two singlemember districts with one majority-white district and one majority-black district. ${ }^{410}$ Because County $A$ has more residents than can be allocated to two districts, a third legislative district, centered on an adjoining county, would include a portion of County $A$ voters. This district is predominantly white.

Because the first option submerges and the second fragments black voters, each would fail the Gingles test, both with respect to membership in the state legislature and to membership on the delegation. Under those options, black voters cannot determine the outcome of elections for any member of the legislature or the delegation, and so their votes are diluted.

406. The match with the Board of Estimate case is in fact a close one. The city-wide members and the borough presidents became members of the Board upon their election to their respective offices and by virtue of the city charter provision, which provided that election to these offices would determine membership on the Board. Given this provision, no discretion was vested in any entity other than the electorate to determine who sat on the board. Legislative rules-whether de facto or de jure-determine membership on legislative delegations. These rules, whether enacted or the result of longstanding legislative practice, similarly give no discretion to any other entity to change the composition of the delegation. Election to the state legislature is election to the delegation.

407. 478 U.S. 30 (1986).

408. Id. at 56. See supra notes $235-41,391$ and accompanying text.

409. The demographics and districting plan for County $A$ are similar to those of Dougherty County. See supra notes 312-16 and accompanying text.

410. There are, of course, an almost infinite number of variations on these primary options. See generally ELECTORAL LAWS AND THER POLITICAL CONSEQUENCES (Bernard Grofman \& Arend Lijphart eds., 1986) (overview of various electoral laws). Here, a discussion of these elaborate options is not necessary to explain how traditional standards fail to capture delegation dilution. 
The third option recognizes the concentration of black voters in County $A$, and so the legislative reapportionment would pass muster under Gingles. ${ }^{411}$ Nonetheless, black votes have less clout than white votes in the selection of the legislative delegation. The constituency, for purposes of electing members to the delegation, has been expanded to add a second representative elected by white voters. If one measure of political opportunity for black voters is the ability to elect representatives of their choice to office, it would appear that the ability of black voters to participate in the political process has been diminished. The Gingles test cannot assess this form of vote dilution.

Hence, definitions of dilution developed in the legislative reapportionment context are inadequate to measure delegation dilution. ${ }^{412}$ Although both types of dilution occur as a result of the way in which legislative lines are drawn, the potential for delegation dilution arises not from the decision to draw an insufficient number of legislative districts or to split communities of voters. Instead, dilution may result from the decision to include voters outside the jurisdiction in the selection of delegation members. Whether that decision was made for the purpose of disadvantaging black voters-or simply because additional voters were necessary to satisfy one-person, one-vote requirements-the impact is the same. Voters from an adjoining county are permitted to vote in an election determining the candidate who will sit as a member of the delegation for the first county. ${ }^{413}$ This occurs each time a legislative district line crosses a county boundary. Reapportionment thus can either expand or contract the constituency that elects members to the delegation. ${ }^{414}$

411. Under option three, the districting plan has taken into account geographically compact minority voters, so the third Gingles factor is not present.

412. Existing doctrine is tied to a narrow conception of voting power that ends at election day. See supra notes 258-64 and accompanying text. The measure of dilution is whether the legislative lines are drawn so that groups of voters, voting alike, form a "bloc" sufficient to determine the outcome of elections. This measure is narrowly tailored to the notion of a single office and does not look beyond election day to the various arrangements that determine what these representatives actually do.

413. This analysis defines the issue as a traditional vote dilution problem under the Voting Rights Act in order to demonstrate the potential for race discrimination. An alternative way to frame the issue would be to look at the structure of the delegation as an extension of the franchise to voters living outside of the jurisdiction. Viewed in this way, these structures might be thought to violate traditional Equal Protection principles by permitting voters with no substantial interest in the operation of the delegation nevertheless to "vote" for members of the delegation. See, e.g., Hogencamp v. Lee County Bd. of Educ., 722 F.2d 720 (11th Cir. 1984) (residents of cities served by independent school boards had no substantial interest in operation of separate county school system and statute permitting city residents to vote in county school board elections was unconstitutional as applied); Brown v. Board of Comm'rs, 722 F. Supp. 380 (E.D. Tenn. 1989) (city ordinance permitting nonresidents who owned trivial amounts of property to vote in city elections violated the Equal Protection clause).

414. See infra notes 430-31 and accompanying text for an analysis of why the voting strength of the county's black voters is an appropriate benchmark for delegation dilution. 


\section{Alternative Measures}

Since the Gingles standards cannot be used to evaluate delegation dilution, it is necessary to turn to doctrine developed outside the context of challenges to election systems. ${ }^{415} \mathrm{~A}$ close parallel to this type of dilution is discussed in the annexation cases decided under section 5 of the Voting Rights Act. ${ }^{416}$ An annexation, by changing a city's boundary lines, has the potential to add voters to the city rolls and change the city's election constituency. ${ }^{417}$ This in turn affects the relative influence of black voters in city elections. Likewise, a reapportionment changes the election constituency for legislative delegations by expanding legislative districts beyond the county's borders. ${ }^{418}$

The Supreme Court first explained how annexation can affect voting power in Perkins v. Matthews. ${ }^{419}$ The Court offered two formulations for the relationship between annexation and voting: "(1) by including certain voters within the city and leaving others outside, [the annexation] determines who may vote in the municipal election and who may not; (2) it dilutes the weight of the votes of the voters to whom the franchise was limited before the annexation.... ${ }^{\wedge 20}$ The Court viewed annexations as boundary line changes that

415. Existing doctrine does provide some analogy to delegations and therefore provides a useful starting point. An alternative to squeezing delegations into existing doctrine is simply to ask "how much more influence could black voters have under a different system?" Under this approach, the technical characterization of the delegation as an elected body has far less significance than the role of the delegation and its impact on black voters. For a provocative example of this kind of interpretation, see Guinier, supra note 29 , at 1459-1487 (arguing for "interest representation" as alternative voting rights concept).

416. Although section 2 presumably covers annexations, which, by changing the election constituency, can affect the ability of voters to "participate in the political process and elect representatives of their choice" to office, only a few courts have considered such challenges. See, e.g., Dotson v. City of Indianola, 739 F.2d 1022, 1023 n.I (5th Cir. 1984) (remanding to district court for section 2 determination and other purposes); United States v. Town of Indian Head, No. R86-964 (D. Md. Nov. 18, 1986) (approving final consent judgment and final decree); Tolbert v. City of Bessemer, No. CV-83-P-3050-S (N.D. Ala. Oct. 21, 1985) (approving amended consent decree).

417. Typically, only city residents may vote in municipal elections.

418. It is in this sense that reapportionments can be viewed as "temporary annexations" of voters, who then become eligible to vote for members of the county's delegation. The constituency remains in place until the next reapportionment, when the district lines in a given county may be reconfigured. Each reapportionment has the potential to change the voting constituency by adding a greater or lesser number of voters from an adjoining county to the delegation or by splitting the county among a greater number of legislative districts. The term "annexation" is used loosely in making the analogy between city boundary changes and legislative reapportionments as they affect county delegations. Strictly speaking, an annexation entitles residents of the annexed property to all of the benefits and burdens of city residence; a reapportionment, on the other hand, only affects the voting status of residents outside of the county vis-a-vis the members of the delegation.

419. 400 U.S. 379 (1971). Actually, Gomillion v. Lightfoot, 364 U.S. 339 (1960), was the first Supreme Court case to tie city boundary line changes to the right to vote. Gomillion explained how a deannexation prohibits the exercise of the franchise by removing voters from a jurisdiction where they could cast a ballot. It is Perkins, however, that first offered a theory of vote dilution through annexation; that is, where voting power, and not the absolute right to vote, was infringed.

420. Perkins, 400 U.S. at 388. It is the second formulation of vote dilution in Perkins that resembles the vote dilution that occurs through the reapportionment of delegations. Voters are not prohibited from voting, as they would be by a deannexation, see Gomillion, 364 U.S. at 341 , or a refusal to annex, see City of Pleasant Grove v. United States, 479 U.S. 462 (1987). Instead, their votes are worth less because they are a smaller percentage of the voting pool. 
had the same potential impact on voting as reapportionments because they "change ... the composition of the electorate" entitled to vote in elections. ${ }^{421}$

The Supreme Court has maintained its view that annexations may dilute the votes of black voters who were residing in the city before the annexation and whose percentage of the population was decreased as a result. ${ }^{422}$ The question of how much dilution constitutes discrimination has not been firmly established because, in many instances, the Court has not been faced with the question of whether the annexations, standing alone, are discriminatory. ${ }^{423}$ Although the Court has declined to hold every annexation that reduces the percentage of black residents in a city's population a violation of section $5,{ }^{424}$ it has nevertheless upheld lower court findings that annexations diluted black voting strength even where blacks were a numerical minority in a city both before and after the annexations. ${ }^{425}$ Moreover, when the annexation is under-

421. 400 U.S. at 389. As a result, the Court held that revisions of boundary lines fall within the scope of section 5 as "changes having a potential for racial discrimination in voting . . . " Id. at 388-89. In analogizing annexations to changing the boundaries of election districts, the Court cited the finding of the United States Civil Rights Commission that "gerrymandering and boundary changes had become prime weapons" for voting discrimination. Id. at 389. The Court cited language from a Commission report noting that " $[t]$ hese measures have taken the form of switching to at-large elections where Negro voting strength is concentrated in particular election districts, facilitating the consolidation of predominantly Negro and predominantly white counties, and redrawing the lines of districts to divide concentrations of Negro voting strength." Id. at 389.

422. See, e.g., City of Pleasant Grove v. United States, 479 U.S. 462 (1987); City of Port Arthur v. United States, 459 U.S. 159, 165-66 (1982); City of Rome v. United States, 446 U.S. 156 (1980); City of Richmond v. United States, 422 U.S. 358, 368, 370 (1975).

423. For instance, in Perkins, the Court determined only that the annexations to Canton, Mississippi had to be reviewed for discriminatory effect. 400 U.S. at 383-84, 388-89. The district court had found that blacks were a majority of the city's registered voters both before and after the annexation. Id. at 382 n.4. In Port Arthur, the parties conceded that the annexation-which reduced blacks from $45 \%$ to $41 \%$ of the population-was dilutive, but disputed whether the remedy was sufficient to dispel the adverse effect of the annexation. The question of whether annexations are dilutive is determined in the context of the particular method of election used in the city. In this posture, the critical issue is the impact of the election system, not whether black voters have decreased as a percentage of the population. Where the city can prove that its method of election "fairly reflects the strength of the [minority] community as it exists after the annexation," City of Rome, 446 U.S. at 187 (citing City of Richmond, 422 U.S. at 371), the annexation is not discriminatory, absent a finding that it was adopted with the purpose of minimizing black voting strength. As City of Richmond explained, the method of election must "afford [minority voters] representation reasonably equivalent to their political strength in the enlarged community" to cure the impact of an annexation that reduces minority voters as a percentage of the city's population. 422 U.S. at 370 .

424. Despite the diminution of black voting strength, the Court in City of Richmond found that the ward plan adopted for city elections cured this discriminatory effect. 422 U.S. at 372,378 . With respect to the district court's finding that the annexation had been adopted with a discriminatory purpose five years earlier, the Court remanded the case to the district court for a determination as to whether nondiscriminatory reasons supported the annexation at the present time. Id. at 374, 378-79.

425. In City of Rome, the Court noted that although blacks were only $23.4 \%$ of the city's population, 446 U.S. at 159, and had never elected any city officials, the annexations nonetheless "reduced the importance of [their] votes." $I d$. at 187 . Several lower court decisions provide some indicia of the amount of dilution considered discriminatory under section 5, in the absence of ameliorative election changes. See, e.g., City of Petersburg v. United States, 354 F. Supp. 1021, 1024 (1972), aff d, 410 U.S. 962 (1973) (finding reduction of blacks as percentage of city's population from $55 \%$ to $46 \%$ sufficient to establish discrimination). Under applicable section 5 standards, the measure of discriminatory effect is whether the change is "retrogressive"; that is, whether minority voters are worse off than they were before the change. See Beer v. United States, 425 U.S. 130, 141 (1976) ("[T]he purpose of $\$ 5$ has always been to insure that no voting-procedure changes would be made that would lead to a retrogression in the position of racial 
taken with the purpose of discriminating against black voters, almost any diminution in voting strength is sufficient to constitute dilution. ${ }^{426}$

The similarity between reapportionment as it affects the constituency for delegation elections and annexation as it affects the constituency for city elections suggests a means of measuring vote dilution in the context of legislative delegations. The analogy between legislative reapportionments and annexations is not perfect, however. ${ }^{427}$ More importantly, this analysis has not benefited from the factual development and doctrinal refinement that occurs in litigation, ${ }^{428}$ since courts have not yet explored the potential for dilution by those structuring legislative delegations. The analysis is thus offered as a model for conceptualizing delegations, rather than as a definitive legal standard against which to measure vote dilution. ${ }^{429}$

The first question that arises under this formulation is: against which benchmark do we measure minority voting strength? In other words, conceding that adding noncounty voters to the delegation constituency affects the voting strength of minority voters, what should be the correct influence of minority voters $?^{430}$ The appropriate measure of minority voting power should be their

minorities with respect to their effective exercise of the electoral franchise."). Since the jurisdiction seeking to implement the change bears the burden of proof, City of Rome, 446 U.S. at 172, the standards in section 5 may not be transferred wholesale to section 2 , where the burden remains with the parties challenging the dilutive practice.

426. In Pleasant Grove, the Court sustained a finding of dilution where the effect on black voters currently living in the city was de minimus. Although only two black residents were registered to vote in the "all-white enclave" before the annexation, 479 U.S. at 465 , the annexation "provide[d] for the growth of a monolithic white voting block, thereby effectively diluting the black vote in advance." Id. at 472.

427. For instance, annexations typically are permanent, whereas reapportionments remain effective only for approximately one decade. Annexations affect voting for offices that are formally denominated as elected offices, while reapportionments affect an office that is functionally an elected office but is not denominated as such. Moreover, the city has the opportunity to remedy a dilutive annexation through ameliorative changes to its election system. The cure for the reapportionment of a legislative delegation that diminishes minority voting strength is less clear. See infra Part III(D).

428. For a discussion of the relationship of factual development to legal theory, see generally DAVID A. BINDER \& PAUl BERGMAN, FACT INVESTIGATION: FROM HYPOTHESIS TO PROOF (1984); Gerald P. Lopez, Reconceiving Civil Rights Practice: Seven Weeks in the Life of a Rebellious Collaboration, 77 GEO. L.J. 1603, 1629-1649 (1989). The comments of the Supreme Court with respect to constitutional claims of racial gerrymandering are equally applicable here: "[For claims] which derive content by an interpretive process of inclusion and exclusion, it is imperative that generalizations, based on and qualified by the concrete situations that gave rise to them, must not be applied out of context in disregard of variant controlling facts." Gomillion v. Lightfoot, 364 U.S. 339, 343-344 (1960). Traditional vote dilution litigation has its roots in Reynolds v. Sims, 377 U.S. 533 (1964), and the 25 years since Reynolds have required attention to the meaning of fair representation. It was not until 1986 that the Supreme Court refined the test for dilution through the use of multimember districts, see Thornburg v. Gingles, 478 U.S. 30 (1986), and the parameters of other types of claims are still unclear, see supra notes $235-46$ and accompanying text.

429. In describing their proposal for assessing racial vote dilution in at-large systems, James Blacksher and Larry Menefee express similar sentiments: "[L] ike every other constitutional or legal standard of proof, the one proposed here, once it is tested in the continuum of real world circumstances, may require refinement and modification." Blacksher \& Menefee, supra note 167, at 64 .

430. As Justice O'Connor put the issue in Gingles: "[I]n order to decide whether an electoral system has made it harder for minority voters to elect the candidates they prefer, a court must have an idea in mind of how hard it 'should' be for minority voters to elect their preferred candidates . . ." 478 U.S. at 88 (O'Connor, J., concurring in the judgment). The Court in Gingles struggled with this question in determining that the single-member district is the appropriate benchmark against which to compare the relative ability 
voting power in the county governed by the delegation. ${ }^{431}$ The primary role of the delegation is to consider matters affecting local government, and delegation members are functionally representatives of the county. The appropriate comparison is, then, between the voting strength of minority voters in the county and their strength in the "enlarged" constituency.

Under this analysis, the structure of the delegation is potentially dilutive any time legislative district lines cross over county boundaries to include voters from adjoining counties in the delegation's election constituency. ${ }^{432}$ Black voting strength would actually be diluted (1) in counties that contain significant numbers of black voters; and (2) where the addition of noncounty voters to the delegation's constituency (through either fragmentation or submergence) adds delegation members elected by white voters. ${ }^{433}$

of black and white voters to elect their candidates. Id. at 50 . Although this measure is clearly unsatisfactory in many contexts, see Karlan, supra note 196, at 201-04, 221-36, other measures may also be problematic. See generally Bernard Grofman, Alternatives to Single-Member Plurality Districts: Legal and Empirical Issues, in REPRESENTATION AND REDISTRICTING ISSUES (Bernard Grofman et al. eds., 1982); Note, Alternative Voting Systems as Remedies for Unlawful At-Large Systems, 92 YALE L.J. 144, 155-56 (1982) (discussing possible disadvantages of cumulative voting). The question of discriminatory effect is perhaps the most difficult question facing voting rights advocates as well as other civil rights advocates. $C f$. Minna J. Kotkin, Public Remedies for Private Wrongs: Rethinking Title VII Back Pay Remedy, 41 HASTINGS L.J. 1301,1330 (1990) ("[D]isparate impact test has spawned a jurisprudence of incredible complexity."); Norman C. Amaker, De Facto Leadership and the Civil Rights Movement: Perspectives on the Problems and Role of Activists and Lawyers in Legal and Social Change, 16 S.U. L. REV. 1, 40-42 (1989) (identifying problem in determining "core" meaning of effects discrimination under Title VII). Once we leave the confines of decisions made expressly to harm minorities, fairness and equality become more difficult to assess.

431. By analogy to Gingles, voting power should be measured against other available alternatives. As the Court noted, "[t]he single-member district is generally the appropriate standard against which to measure minority group potential to elect because it is the smallest political unit from which representatives are elected." Gingles, 478 U.S. at 50 n.17. For legislative reapportionments, the single-member district may be the best districting alternative to a multimember plan, but for delegations the logical alternative is a district that is commensurate with the county. But for the decision to vest power over local matters in the state legislature, local governance power would be exercised by the county as the appropriate political unit. To the extent that the state decides to vest substantial control over local matters in a group reflecting the crazy quilt pattern of selecting delegation members, that choice cannot be permitted if it disadvantages black voters.

432. Not every reapportionment that diminishes minority voters' share of the election constituency would violate the Voting Rights Act. The reapportionment might make minority voters a smaller percentage of the delegation's constituency than of the county's voting constituency, but nevertheless have only a minimal impact on minority voters' influence on the delegation. For example, if the county's minority population was already too small to influence the outcome of local elections, then black voters would suffer no additional disadvantage by being "submerged" in the larger delegation district.

433. The analysis, of course, assumes racial bloc voting. See supra notes $238-40$ \& $391-94$ and accompanying text. This dilution would occur irrespective of a legislative reapportionment that, with respect to elections to the state legislature, meets the requirements of the Voting Rights Act. A legislative reapportionment plan might contain only single-member districts, see Parker, supra note 208, at 88 (noting tendency for multimember districts to submerge black voting strength), and fragment no concentrations of black voters, $i d$. at $89-92$ (fragmentation of concentrations of minority voters between legislative districts dilutes black voting strength), yet still have the effect of diluting the votes of minority voters with respect to the legislative delegation. This is the inevitable effect of structuring delegations so that voters who live outside of the affected jurisdiction have a voice in determining who sits on the delegation. See supra note 301 for an explanation of how legislative reapportionments may fairly reflect minority voting strength with respect to the legislature but nonetheless dilute the delegation. 
The legislative delegations for Dougherty and Richmond Counties, Georgia illustrate the dilutive impact of a districting plan that fragments the county and imports a large number of noncounty voters into the delegation constituency. The delegation for Burke County, Georgia similarly demonstrates dilution in a county that donates its residents to a larger legislative district and is thus submerged in a predominantly white district. ${ }^{434}$ In Dougherty and Richmond Counties, a legislative districting plan centered on the county resulted in the election of a majority-black delegation and a racially balanced delegation respectively. The incursion from adjoining counties added a predominantly white constituency that elected an additional white member to these delegations. Had the Justice Department not intervened, black voters would have had a correspondingly smaller influence in delegation decisionmaking. ${ }^{435}$

In Burke County, black residents have obtained a significant voice in the county electorate, but their voice is muted because the electorate for the delegation has been expanded. ${ }^{436}$ As a numerical minority of the voters in a predominantly white legislative district, they have little influence on the election of members to the delegation. The structure of the legislative delegation thus dilutes the votes of black voters in Burke County.

\section{The Enforcement Mechanism}

Given the vast potential for discrimination in the structure of delegations and their procedures, the mechanisms for uncovering this discrimination are critical. This is especially true in light of the near invisibility of delegations to all but local observers. Since delegations have gone about their business in virtual obscurity, the risk remains that they will continue to operate free of legal constraints.

434. The delegation reapportionments of Dougherty and Richmond Counties differ from that of Burke County in one significant respect. While the first two reapportionments appear deliberately designed to minimize black voting strength, the Burke County reapportionment may be the inevitable result of the fact that black voters in the county are too scarce to constitute a majority in a legislative district. In the former reapportionment, the legislative plan could be redrawn to the cure the taint, while in the latter, the only feasible remedy appears to have been a linkage with Richmond County or a transfer of power to a different level of government. See infra notes 463-64 and accompanying text for a discussion of the remedial problems faced in such situations.

435. In Dougherty County, discrimination occurs despite the fact that the racial makeup of the delegation mirrors that of the county. Blacks constitute one half of the county's voters and can elect one-half of the delegation members. The dilution arises from the fact that the state has taken steps to reduce the influence of black voters from what it would otherwise have been under a plan that was free from impermissible racial considerations. Dilution would be even clearer in a plan where the delegation's racial makeup did not mirror that of the county. For example, suppose that Dougherty County was entitled to two Iepresentatives, that one majority-white and one majority-black district could be drawn within county borders, and that the state drew a third majority-white district within only a piece of the county. In this situation, the county's voters would have only one third of the representation on the delegation, while constituting one half of the voters.

436. See supra note 360 and accompanying text. 
Section 5 of the Voting Rights Act provides a ready mechanism for monitoring changes in the membership of legislative delegations. ${ }^{437}$ Though section 5 has many nuances and has been the subject of extensive commentary, ${ }^{438}$ its operation is fairly straightforward for the purposes of this discussion. Section 5 applies whenever a covered jurisdiction adopts any change affecting voting. Covered jurisdictions are defined as states or political subdivisions ${ }^{439}$ with a history of voting discrimination and low voter registration or turnout. ${ }^{440}$ The language of section 5 speaks broadly to voting changes, which it defines to include any change in a "voting qualification or prerequisite to voting, or standard, practice, or procedure with respect to voting." $\$ 41$

Section 5 covers many of the states in which delegations exercise broad powers. ${ }^{42}$ Legislative reapportionments ${ }^{443}$ and annexations, ${ }^{444}$ the two factors that have the greatest impact on who sits on legislative delegations, are voting changes within the meaning of section 5 . The scope of the section, coupled

437. Theoretically, section 2 would also apply, but would in reality seem to be a less effective remedy. Because section 2 lacks an enforcement mechanism like that in section 5 , the burden would fall on private litigants or the federal government to uncover discrimination and file a lawsuit in federal court. To date, few section 2 lawsuits have ventured beyond the familiar issues surrounding vote dilution in a formally elected bodies, and it is unlikely that there will be a wholesale reversal of this trend in the near future.

438. See, e.g., Hiroshi Motomura, Preclearance Under Section 5 of the Voting Rights Act, 61 N.C. L. REV. 189 (1983) (arguing that the retrogression test has been supplanted in the administrative preclearance process by constitutional vote dilution factors); Cynthia Grace Lamar, Note, The Resolution of Post-Election Challenges Under Section 5 of the Voting Rights Act, 97 YALE L.J. 1765, 1766 (1988) (proposing expanded role for federal district courts in determining the existence of discrimination).

439. The Act defines "political subdivision" as counties, where the county conducts voter registration, or as any other local entity which conducts voter registration. 42 U.S.C. $\$ 1973 l(c)(2)$ (1988). The entire states of Alabama, Alaska, Arizona, Georgia, Louisiana, Mississippi, South Carolina, Texas, and Virginia are covered by section 5, as well as parts of California, Florida, Michigan, New Hampshire, New York, North Carolina, and South Dakota. A complete list of the covered jurisdictions appears in the appendix to Procedures for the Administration of Section 5 of the Voting Rights Act of 1965, As Amended, 28 C.F.R. pt. 5 I (1991) [hereinafter Section 5 Appendix].

440. Specifically, section 4(b) of the Act, 42 U.S.C. $\S 1973 \mathrm{~b}(\mathrm{~b})$ (1976), covers states or political subdivisions that meet the two-part test for coverage. Coverage is triggered for any jurisdiction that has (1) maintained a "test or device" as defined in section 4 (c), 42 U.S.C. $\S 1973$ b(c) (1976) or 42 U.S.C. $\S$ $1973 b(f)$ (1976), as of a certain specified date, and (2) where the number of registered voters on the same date was less than $50 \%$ of the jurisdiction's voting age population, or the voting tumout for that year's presidential election was less than $50 \%$ of its voting age population. States and political subdivisions initially were covered by virtue of maintaining such tests or devices, and having low registration rates on November 1,1964 , and with the requisite low turnout for the 1964 presidential elections. In 1970, the Act was amended to extend coverage to states and political subdivisions that met these conditions on November 1, 1968 and in the 1968 presidential election. In 1975, the Act was amended again to extend coverage to states and political subdivisions that met these conditions on November 1,1972 and in the 1972 presidential election, and to extend coverage to language minorities under certain specified conditions. 42 U.S.C. $\$ 1973 b(b)(f)(3)$.

441. 42 U.S.C. \$ 1973c. Without preclearance, covered jurisdictions may not implement changes adopted after the date the jurisdiction became subject to section 5 coverage. See Section 5 Appendix, supra note 439 , for the applicable trigger dates.

442. Delegations are especially influential in Alabama, Florida, Georgia, Mississippi, North Carolina, and South Carolina. See sources cited supra note 23. The entire states of Alabama, Georgia, Mississippi and South Carolina are covered by section 5 , and 40 counties in North Carolina are covered. See supra note 439.

443. Georgia v. United States, 411 U.S. 526 (1973).

444. Port Arthur v. United States, 459 U.S. 159 (1982); City of Rome v. United States, 446 U.S. 156 (1980); City of Richmond v. United States, 422 U.S. 358 (1975); Perkins v. Matthews, 400 U.S. 379 (1971). 
with its application to Southern states, means that section 5 will apply to changes in delegation membership in most states in which delegations are important actors in the legislative process.

When a jurisdiction adopts a voting change that falls within the scope of section 5, it must obtain approval for the change from the United States Attorney General or the United States District Court for the District of Columbia. The process of securing approval is referred to as "preclearance,"445 and the statute provides a complex administrative and judicial mechanism for determining whether or not discrimination has occurred. ${ }^{446}$ When a jurisdiction does not seek preclearance, the United States Department of Justice and private litigants can sue in federal court to force the jurisdiction to submit the change. ${ }^{447}$ Although the statute offers judicial preclearance as an alternative to administrative preclearance, ${ }^{448}$ most jurisdictions seek approval from the Attorney General. ${ }^{449}$ Thus, in most cases, the Justice Department decides whether voting changes satisfy section 5 standards. ${ }^{450}$

Each time a jurisdiction submits a reapportionment or an annexation for section 5 review, the Justice Department could expand the scope of its review to include the impact of these changes on the delegation. Specifically, the Department could require the state to supply this information and withhold preclearance unless the jurisdiction could satisfy its burden of showing that the change did not have a discriminatory impact on the delegation. ${ }^{451}$

The burden of proof may be especially critical in deciding the novel issues presented by legislative delegations. The Justice Department may be reluctant to undertake a wholesale examination of state legislative reapportionments on delegation membership. When state and local governments bear the burden of establishing that the choices they have made regarding their governmental processes are nondiscriminatory, the Department is more likely to object to the change.

445. AMAKER, supra note 369 , at 141. For a detailed description of the preclearance process, see generally HOWARD BALL ET AL., COMPROMISED COMPLIANCE: IMPLEMENTATION OF THE 1965 VOTING RIGHTS ACT (1982); John P. MacCoon, The Enforcement of the Preclearance Requirement of Section 5 of the Voting Rights Act of 1965, 29 CATH. U. L. REV. 107 (1979).

446. Jurisdictions that oppose the administrative decision of the Attorney General may file a de novo appeal with the United States District Court for the District of Columbia. The case is heard by a three-judge panel, and that court's decision may be appealed to the Supreme Court. 42 U.S.C. $\$ 1973 \mathrm{c}$ (1988).

447. Allen v. Board of Elections, 393 U.S. 544 (1969).

448. See 42 U.S.C. § 1973 c (1988).

449. AMAKER, supra note 369 , at 142 . By initially seeking approval from the Attomey General, the jurisdiction does not forfeit its right to obtain preclearance from the court.

450. Within the Justice Department, the Voting Section of the Civil Rights Division has the responsibility for administrative preclearance. AMAKER, supra note 369 , at 148.

451. The regulations implementing section 5 set forth the required contents for submissions, 28 C.F.R. $\S \S 51.27-.28$ (1991), and could be revised to require information on reapportionment's impact on the delegation. Even as the regulations now stand, the Justice Department can request additional information about the proposed change. 28 C.F.R. § 51.37(a) (1991). The Justice Department may withhold preclearance until the information submitted in response is satisfactory, 28 C.F.R. $\$ 51.37$ (c) (1991), or object if the information is not forthcoming within 60 days. 28 C.F.R. $\S 51.40$ (1991). 


\section{The Remedy}

The goal in remedying delegation dilution is to reflect black voting strength in the delegation membership. ${ }^{452}$ Typically, vote dilution is remedied by altering the lines for election districts, and thereby changing the composition of the electorate entitled to vote for a particular office. ${ }^{453}$ Although this and several other remedial possibilities exist for delegation dilution, all but one impose unacceptable costs in terms of prevailing legal standards and policy considerations. Thus, it appears that only the most stringent remedy-divesting the delegation of jurisdiction and returning control to local government-is viable.

In applying the standard vote dilution remedy to delegations, noncounty voters could be removed from the delegation's constituency in several ways. When a legislative reapportionment has caused the dilution, district lines could be adjusted to remove the offending legislative district from county boundaries. Such a remedy is feasible, however, only in the few instances in which minor adjustments could remedy the dilution, such as when the dilutive district fragments only a small, sparsely-populated portion of the county. This remedy could be implemented in Dougherty County, for example, where the 3,500 residents of the finger district could be distributed among existing districts. ${ }^{454}$

In most instances, however, this remedy would require unacceptable alterations in district boundaries. For example, dilution in submerged counties such as Burke County cannot be remedied through this means because submerged counties by definition contain too few residents to constitute a legislative district. Any district seeking to recognize black voting strength, therefore, would necessarily exclude county voters in numbers sufficient to raise serious one-person, one-vote problems. Even where the problem is fragmentation, rather than submergence, equal population problems likely would arise. In all but those counties with fragmentation slivers, district line adjustments would cause a spillover effect in adjoining counties that would require district lines to be redrawn. The membership of delegations in those counties would, in turn, be affected, and the impact on statewide districting would be enormous. Ultimate$1 y$, the goal of maintaining county boundaries would collide with the oneperson, one-vote principle, ${ }^{455}$ making it impossible to accommodate both goals.

With respect to annexations, legislative lines could also be redrawn to remove the annexed territory from the adjoining legislative district. This result could be accomplished by expanding an existing city district to encompass the annexed territory. Although the remedy poses the same disadvantages as those

452. The delegation constituency would fairly reflect black voting strength where the percentage of black voters in the delegation districts is nearly equal to the percentage of black voters in the county.

453. See, e.g., Parker, supra note 208, at 111-13; Guinier, supra note 29, at 1426-27.

454. See supra notes $312-16,329$ and accompanying text.

455. See supra notes $282-95$ and accompanying text. 
described above, some annexations would have few enough residents to render the population consequences minimal. ${ }^{456}$

When this remedy is not viable, the alternative means of removing noncounty voters from the delegation's constituency involves voiding the annexation and maintaining the status quo. Because annexations have no immediate impact on legislative reapportionment, city lines could simply be redrawn to make them congruent with legislative districting lines. ${ }^{47}$ This remedy, however, imposes unacceptable costs. Many annexations are undertaken for neutral reasons, such as the desire of residents in the annexed territory to receive city services, ${ }^{458}$ and the racial impact on the delegation may be unintended. In this situation, neutral objectives collide with a racially discriminatory effect on the delegation, and the resolution of this tension is costly.

The essential weakness of line-drawing remedies for delegation dilution is that the lines (whether city boundaries or legislative districting lines) are asked to do too much. In the case of city boundaries, the main purpose is to determine who receives the benefits of city residence, while in the case of reapportionment, the main purpose is to determine the election constituency for the state legislature. In sum, making these lines serve a dual purpose imposes high costs, except in situations where the discrimination is flagrant, and only minor adjustments are necessary. ${ }^{459}$

Another remedial possibility would be to alter the delegation's rules so that delegation members elected by noncounty voters would be prohibited from serving on the delegation. This option does not force the redrawing of district lines, nor does it create the accompanying one-person, one-vote problems. Yet this rule also has serious drawbacks. In the case of fragmented counties, the county residents in the district fragment lying within county boundaries would be deprived of any vote for the delegation, and would in effect have no repre-

456. For example, shifting the 395 residents in the Macon deannexation from one district to another would have been a feasible remedy because it would have had little impact on the reapportionment. See Letter from Neil Bradley, Associate Director, Southern Regional Office, American Civil Liberties Union Foundation, to William Bradford Reynolds, Assistant Attomey General, Civil Rights Division, United States Department of Justice, 5 (Jan. 30, 1985) (on file with author) [hereinafter Bradley Letter]. See supra notes 304,366 and accompanying text for a discussion of the Macon deannexation.

457. Unlike reapportionments, annexations simply add more territory to a political unit (the city) without any resulting change in the population of adjoining legislative districts. By removing this territory from the city limits, the population of legislative districts remains the same and thus one-person, one-vote standards are not compromised. Annexations, of course, may require the city to redraw its local election districts after the next census, but that requirement exists independent of delegation dilution.

458. Haddad, supra note 29 , at 148.

459. These costs cannot be avoided by permitting the annexation to go forward while forcing the adoption of a fairer method of election for the delegation. Although this remedy is feasible for city elections, see City of Richmond v. United States, 422 U.S. 358 (1975), in which city legislators wear only one hat, delegation members also run for the state legislature qua state legislature. Redrawing delegation election districts would also realign legislative districts, leading to the problems discussed supra notes 282-95 and accompanying text. 
sentation on the delegation. ${ }^{460}$ In the case of submerged counties, county residents would be deprived of a delegation because the only eligible member would have been elected by noncounty voters and thus prohibited from serving on the delegation. A remedy that deprives some residents of their voting rights in an effort to protect other voting rights is not effective. ${ }^{461}$

A variation on this theme would permit the delegation member to serve on the delegation, but utilize measures to negate his or her influence in comparison to the will of the "true" delegation members. Consider, for example, a fourperson delegation, three of whose members' districts lie totally within county boundaries, and one whose district fragments the county. This fourth delegation member could be prohibited from voting where his or her vote would make a difference in the outcome (i.e., where the delegation is split two to one and her vote would create a tie), or the remaining delegation members could commit themselves to support any measure that had the support of two of the three "true" members. ${ }^{462}$ This remedy raises difficult definitional problems concerning which delegation members should be subjected to this rule, in addition to the problem, noted above, of depriving some county residents of a delegation vote. Because all of these remedies are unsatisfactory, a remedy divesting the delegation of power over local government in the county in which black votes are diluted must be seriously considered. In situations where altering district lines cannot remedy the dilution, the delegation's power to enact local legislation could be transferred to the appropriate local governing body. ${ }^{463}$ The local governing body would then exercise the legislative duties formerly exercised by the delegation, and the state legislature would retain no control over local legislation. ${ }^{464}$

460. If delegations are elected bodies, depriving an eligible voter of a vote for an elected body would violate the Equal Protection Clause of the Fourteenth Amendment.

461. Although this remedy could be tempered by providing delegation members a vote weighted in proportion to the number of county residents they represent, see Amended Complaint at 17, Blanton v. Campbell, No. 2-91-3635-1 (D.S.C. filed Dec. 12, 1991), this arrangement might still result in delegation dilution. This could occur where the delegation member was the candidate of choice of noncounty voters, but not of county voters. In this situation, noncounty voters would still unduly influence delegation deliberations.

462. A variant of this remedy was suggested by the lawyer representing aggrieved residents in the Macon deannexation. See Bradley Letter, supra note 456. It is not clear that existing legislative rules permit this remedy. GA. H. REP. R. 11, for example, permits delegations to determine the number of delegation members who must agree on proposed legislation, but the rule on its face does not seem to give delegations discretion to exclude members from a vote.

463. This is akin to the remedy in Hardy v. Wallace, 603 F. Supp. 174, 179 (N.D. Ala. 1985), where the court enjoined the enforcement of a statute which transferred appointment authority over the local racing commission from the legislative delegation to the governor, on the grounds that the state did not seek preclearance for this change.

464. Such relief was one of two remedies suggested by the plaintiffs in Blanton v. Campbell, see Amended Complaint at 17, Blanton v. Campbell, No. 2-91-3635-1 (D.S.C. filed Dec. 12, 1991). The plaintiffs gave as their reasons the fact that the work performed by South Carolina delegations "would be better . . . [performed] by each respective county's county government, because said county governments totally are contained within the boundaries of Dorchester County and each member of each county's govemment was and is elected by virtually the same population." Id. at 11 . 
A remedy that requires the court to restructure state and local government may lead to excessive federal intrusion into the affairs of these governments. Nevertheless, the tension between the competing considerations of complying with the one-person, one-vote mandate and tying delegation representation to those voters with a real interest in delegation deliberations makes other remedies unworkable. For many counties, especially submerged counties and those with a high degree of fragmentation, it is not possible to structure the delegation to overcome these difficulties.

Moreover, the decision to vest control over local government functions in delegations is bad policy, even absent the racial politics that have permeated delegation deliberations and structures. Delegations, after all, have outlived much of their usefulness as a means of permitting the state to exercise control over local government. In the past, the membership of delegations was more closely correlated with ties to the local community. Today, membership of delegations reflects a crazy quilt pattern lacking any real connection to local concerns. Under these circumstances, delegations are an historical anomaly and local government is likely better off without them. ${ }^{465}$

The foregoing analysis is in many ways highly formalistic. It applies existing concepts of voting power to legislative delegations, which, when analogized to other kinds of legislative bodies, fit within the contours of this traditional formulation. The analysis does not fully confront the question of the appropriate end point for measuring voting power. Instead, it places itself squarely in the tradition of cases that view the ability to elect candidates to office as the end point of political participation. Part IV addresses the limitations of dilution analysis in dealing with other aspects of voting power.

\section{BEYOND DELEGATIONS: LESSONS FOR LEGISLATIVE FunCTIONS}

An understanding of delegations allows us to parse the facile notion in Presley v. Etowah County Commission that the election of candidates to office is both the beginning and the end of political participation. Because the vast majority of voting rights litigation has targeted the ability of minority voters to elect candidates to office, ${ }^{466}$ legislative rules and procedures ${ }^{467}$ have re-

465. See UNDERWOOD, supra note 20 , at 160 . Of course, there are circumstances in which black voters might prefer delegation control to control at the local level. For example, where the local government structure is discriminatory and local officeholders ignore black interests, blacks might be better off appealing to the member of the local delegation. The solution in this situation would seem to be to make the local government structures responsive to black interests, rather than to vest control in a distant delegation.

466. This litigation has arisen under either the ability-to-elect aspect of section 2 or related concepts under section 5 of the Voting Rights Act, or directly under the Constitution. See supra Parts I(A) \& I(B). The ability of minority voters to elect candidates is critical to a number of goals, among them encouraging greater minority participation in politics; providing role models in the political system for minority voters; and incorporating diverse viewpoints in legislative deliberations. Karlan, supra note 196, at 213-19 (describing these goals generally as goals of civic inclusion); Howard \& Howard, supra note 196, at 1627-33 (describing these goals as justifying "safe" minority districts). 
ceived little attention from voting rights litigators. Voting rights scholarship has followed suit, largely concentrating on descriptive aspects of the statutory scheme or alternative means of furthering the election of candidates whom minority voters support. ${ }^{468}$ As functional governing bodies, delegations provide concrete examples revealing that the election of candidates must be seen as only the beginning of meaningful political participation. Although an exhaustive treatment of this complex topic is beyond the scope of this Article, I offer a brief analysis in order to demonstrate the vast potential for discrimination in the post-election phase that Presley leaves untouched.

A study of delegations demonstrates that the categories of voting rights jurisprudence established by Presley's four-part typology fail to capture the impact of voting in the real world of politics. ${ }^{469}$ Because membership on delegations is directly tied to election outcomes, no doctrinal quantum leap is required to bring delegation structure under the scope of the Voting Rights Act. Once delegations are recognized as functional governing bodies, a straightforward extension of existing voting rights doctrine leads us to view legislative reapportionments as redefining both the state legislature and each local delegation. Both types of reapportionment must be weighed against the requirements of the Act and scrutinized for the possibility of dilution, although the measure of dilution may vary.

Suppose, however, that a given legislature has chosen to manage local government through a different device than legislative delegations. Instead of creating delegations to manage the affairs of local government, suppose the legislature has delegated this responsiblity to a specially designated committee overseeing all local legislation in the state. Or suppose that the state legislature, in response to a legal challenge against the existing delegation system, replaces the local courtesy rule with procedures that vest greater power in the state legislature. Unlike the system analyzed in Part III, in which elections determine delegation membership, these possible mechanisms fall outside the scope of changes identified in Presley that have an "impact on the substantive question whether a particular office would be elective or the procedural question how an election would be conducted." $\$ 70$ Under Presley's analysis, these manip-

467. I use the term "rules and procedures" to encompass the whole continuum of rules, practices, customs, and norms that shape the legislative process and its outcomes. See BARBARA HINCKLEY, THE SENIORITY SYSTEM IN CONGRESS 5 (1971); Heinz Eulau, Committee Selection, in HANDBOok, supra note 20, at 221 (citing KENNETH A. SHEPSLE, THE GIANT JigSAW PuZZLE: DEMOCRATIC COMMITTEE ASSIGNMENTS IN THE MODERN HOUSE (1978)).

468. For representative samples of this work, see Thomas M. Boyd \& Stephen J. Markman, The 1982 Amendments to the Voting Rights Act: A Legislative History, 40 WASH. \& LEE L. REV. 1347 (1983). For exceptions to the general rule, see the sources cited supra note 196 \& infra note 515.

469. The Court characterized the typology as including three kinds of changes in election procedures (manner of voting, candidacy requirements and qualifications, and the composition of the electorate), and a fourth category "termed substantive changes as to which offices are elective"). Presley, $112 \mathrm{~S}$. Ct. at 828 .

470. Presley, 112 S. Ct. at 832 . 
ulations would not implicate voting rights because the delegations would no longer be functionally-elected governing bodies.

Rather than tinkering with delegation structure, the legislature-or the delegation itself - could change internal delegation operating procedures in order to affect the value of the votes cast by delegation members. Black legislators could be excluded from participating in certain aspects of delegation work, or delegation voting rules could be manipulated so that the vote of black members counted for less. These changes also would fall outside the reach of Presley.

In Part IV, I explore a vision of voting rights that would embrace all aspects of decisionmaking by legislative delegations and, by analogy, other aspects of legislative deliberations and policymaking. This Part criticizes Presley and offers a blueprint for future study of the inner workings of the political process. Because of their unique status both as functional governing bodies and as mechanisms for shifting power between local government and the state, delegations can serve as a lens through which to examine the connections between voting and governance severed by Presley. The lessons learned from a study of delegations extend to other aspects of the political process, teaching us that only a functional view of this process can adequately protect voting rights. The Voting Rights Act must be amended for this vision to be fully realized. ${ }^{471}$

\section{A. Delegation Rules and Procedures}

A close look at delegation rules and procedures demonstrates the bankruptcy of Presley's formalistic conception of voting rights. Even if the method of electing the delegation is fair, black voters may nonetheless be denied equal access to the political process. The legislative process may be used to manipulate delegation deliberations and control the outcome of these deliberations at two levels: the delegation's internal decisionmaking processes and the state legislature's oversight of this process.

At the first level, delegation voting rules determine the number of delegation members that must agree before the delegation can approve legislative proposals; ${ }^{472}$ they thus have a direct effect on the likelihood that certain proposals will receive the delegation's imprimatur. Two variants of decision rules

471. See infra note 519 and accompanying text.

472. See supra notes $148-51$ and accompanying text. In some instances, a uniform decision rule applies to all delegations in the state legislature; in others, individual delegations are free to adopt their own rules. Whatever the merits of particular voting rules, granting delegations the discretion to adopt their own decisionmaking rules, and to change those rules at will, can create opportunities for discrimination. Frequent revision of decision rules, or changes that are made shortly after the election of black officeholders, should be particularly suspect. 
generally apply to delegation deliberations: simple majority or supermajority rules.

Although it is impossible to catalog all of the relevant factors, the effect of decision rules depends upon the racial makeup of the delegation and the nature of the delegation's legislative activity. ${ }^{473}$ Typically, supermajority rules are thought to increase minority influence on governing bodies. ${ }^{474}$ They make it easier for minority groups to "veto" actions proposed by the majority and thus may prevent the majority from overriding minority interests. At a minimum, these rules may force legislators in the majority group to barter with those in the minority group - a process referred to as "logrolling"-in order to accomplish the majority's agenda. In a legislative body requiring an affirmative vote of three-quarters of its members, a cohesive minority group that includes one-third of the legislators can influence the legislative agenda by preventing the legislature from taking any action if the minority's goals are not taken into account.

The advantages of supermajority rule for political minorities, however, may not always be present in the context of racial minorities. ${ }^{475}$ The difficulties that racial minorities face in the give-and-take of the political process may make supermajority rules additional barriers to achieving minority political interests. While these rules promote shifting legislative alliances and coalitions, not every legislative arena presents opportunities for this kind of interaction. White legislators may be unwilling to form coalitions with minority legislators, ${ }^{476}$ thus skewing the typical advantages of the rule.

The minority-enhancing value of supermajority rules also assumes that legislators propose similar legislative agendas and are willing to bargain across a wide range of issues. Where legislators sponsor vastly different legislative agendas - for racial or other reasons-controversial proposals might garner the support of fewer legislators. Any increase in the support needed for passage

473. See Richard H. Pildes \& Elizabeth S. Anderson, Slinging Arrows at Democracy: Social Choice Theory, Value Pluralism, and Democratic Politics, 90 CoLUM. L. REV. 2121, 2198 (1990) ("The appropriateness of choosing particular institutional configurations and decision procedures always depends upon the specific historical and social context in which the choice is being contemplated.").

474. Power is distributed differently in legislatures that operate by supermajority rules than in those that employ a simple majority system. David W. Brady \& Charles S. Bullock, II, Party and Factions Within Legislatures, in HANDBOOK, supra note 20, at 139. For a discussion of the impact of supermajority rules on political equality, see Howard \& Howard, supra note 196, at 1634, 1647 \& nn.76, 141. The literature also discusses the use of supermajority rules in the context of nonlegislative decisionmaking. See Joseph Jaconelli, Majority Rule and Special Majorities, 1989 PUB. L. 587, 588-89; Richard L. Revesz \& Pamela S. Karlan, Nonmajority Rules and the Supreme Court, 136 U. PA. L. REV. 1067, 1109-31 (1988).

475. For a general discussion of the pros and cons of supermajority rules as remedies for voting rights violations, see Karlan, supra note 196, at 246 . For a description of the use of majority voting requirements in the United States Congress, the Supreme Court and local government activities, see id. at 245-46.

476. See Sanford Levinson, Gerrymandering and the Brooding Omnipresence of Proportional Representation: Why Won't it Go Away?, 33 UCLA L. REV. 257, 272 (1985) (noting that some unpopular minorities "find themselves ... frozen out of practical power in the legislature because no one will ally with them"). Cf. Bruce A. Ackerman, Beyond Carolene Products, 98 HARV. L. REV. 713 (1985) (discussing difficulties faced by discrete and insular minorities such as racial groups). 
could make it more difficult to enact such proposals, and lead to deadlock. When racial issues provoke controversy, supermajority rules favor the status quo and may undermine the ability of minority representatives to achieve their legislative goals. ${ }^{47}$

Because delegations have not been the subject of comprehensive study, the extent to which discriminatory motives influence the adoption of delegation rules is largely unknown. The story of the Richmond County delegation, however, supplies some evidence that the choice of voting rules has been driven by racial considerations. During a time of racial tension, the two senators on the delegation abandoned their long-standing practice of requiring both to agree on legislation before it passed the delegation. The switch from a supermajority rule (two of two members) to a simple majority (one of two members) increased the likelihood that consolidation legislation opposed by blacks would be approved. Similarly, the switch from a unanimous vote rule to a majority vote rule in the 1960 's may have occurred to counter the growing diversity of delegation membership. ${ }^{478}$

At the second level, the legislature can manipulate the legislative process that reviews delegation actions, either by creating an exception to the legislature's usual rule barring intervention in delegation decisions, or through other measures. Whether implemented formally or as a matter of custom or practice, these procedures can affect both the process of deliberating and the outcomes of deliberations.

For example, the Richmond County delegation implemented several new procedures when considering legislation that would have improved black voters' chances of gaining political power in the City of Augusta. Senator Allgood substituted a consolidation bill for the ward voting bill that had been supported by black constituents and passed by the house delegation members. This move nullified the ward voting bill, and altered the usual procedure whereby local legislation is first introduced in the house, and then, once approved, is considered by the senate. ${ }^{479}$ Senator Allgood also backed a rule change making it easier for the legislature as a whole to veto delegation actions. ${ }^{480}$ The status quo favored white voters, and the new procedures permitted the legislature to overrule a renegade delegation that might have enacted legislation favorable to the black residents of Augusta. It is not coincidental that the new rule was enacted while the delegation debated legislation with potentially significant racial repercussions.

477. See Operation PUSH v. Mabus, 932 F.2d 400, 408 \& n.6 (5th Cir. 1991) (bill to increase voter registration opportunities in Mississippi received simple majority but not the required three-fifths majority for passage); Karlan, supra note 196, at 247.

478. See supra note 148.

479. See supra note 166.

480. See supra note 171 and accompanying text. 
The delegation from Fulton County, Georgia, an area that includes the city of Atlanta as well as its suburbs, provides a more blatant example of how legislative intervention can undercut delegation decisions to the detriment of black voters. ${ }^{481}$ In 1981 , all county delegations in Georgia drafted reapportionment plans for their respective geographic areas. ${ }^{482}$ The proposal adopted by the Fulton County delegation (dominated by black Democrats and white Republicans) called for nineteen single-member districts and eliminated the atlarge seats that had existed under the previous plan. ${ }^{483}$ When a number of reapportionment plans came up for a floor vote, the house approved the plans drafted by every delegation except Fulton County's. The house rejected the Fulton delegation's plan as written, and amended it by a vote of 125-28 to include seventeen single-member districts and two at-large seats. ${ }^{444}$ The amended plan was ultimately enacted by the legislature as a whole. ${ }^{485}$ During the floor debate, Representative Bob Holmes, a black member of the delegation, described the amendment as "an attempt to go around the committee process and the Fulton County delegation." ${ }^{\$ 486} \mathrm{~A}$ white Republican member of the delegation noted that "[the house had] sent a clear message to the people of Georgia that only a few people are allowed in the Georgia legislative process. . . . And they are white Democrats." 487

The "rules" followed in the post-1990 Georgia state legislative reapportionment suggest that racial factors may still affect the process. In at least one instance, the house reapportionment committee overruled the proposal of a local work group and replaced an apparently fair plan for the Dougherty County delegation with one that clearly diluted the influence of black voters. ${ }^{488}$

481. Although a court could review the Fulton County reapportionment under classic reapportionment doctrine, my approach focuses on the fairness of the reapportionment process rather than on whether the substantive result satisfied the Voting Rights Act.

482. Busbee v. Smith, 549 F. Supp. 494, 503 (D.D.C. 1982), aff d, 459 U.S. 1166 (1983). The Busbee decision also details the racially motivated maneuvering that characterized the reapportionment of congressional districts in the Fulton County area.

483. Because Fulton County had lost population during the past decade, the 24 seats it claimed under the earlier plan had to be reduced to 19 . Of these 24 seats, 21 were elected from districts and three were elected at large. Beas Cutts, Clash Assured on House Remap, ATLANTA CONST., Aug. 26, 1981, at 1A [hereinafter Cutts, Clash Assured]; Beas Cutts, House, Senate Face Redistricting Decisions Today, ATLANTA Const., Aug. 27, 1981, at IA [hereinafter Cutts, Redistricting Decisions].

484. Linda Field, House Tears Apart Fulton Remap Plan, ATLANTA CoNST., Aug. 28, 1981, at 1A (reporting that "most black members" and "all the Fulton County Republicans" supported the pure singlemember district plan).

485. By custom, the senate had routinely rubber-stamped the reapportionment plan for the house, and vice-versa. Cutts, Clash Assured, supra note 483 , at $1 \mathrm{~A}, 8 \mathrm{~A}$.

486. Field, supra note 484 , at IA.

487. Id.

488. In the Dougherty County gerrymander, see discussion supra notes 307-29 and accompanying text, the house reapportionment committee added a "finger district" to the work group's proposal. The amended plan was adopted by the house, and encountered a section 5 objection from the Justice Department. More importantly, the work group procedures may have limited the influence of black voters in drafting reapportionments. See discussion infra notes 496-501 and accompanying text. 
Although the holding in Presley would reach the procedures for selecting delegation members, it would not reach manipulations of legislative rules and procedures such as those just discussed. Black legislators participated freely during both the Fulton County reapportionment and the Richmond County delegation deliberations, but their ability to influence the legislative process was diminished by altering internal delegation decision mechanisms and manipulating delegation autonomy. The election of black representatives did not translate into voting power for their constituents. On the contrary, the legislative process translates constituent preferences into substantive action, ${ }^{489}$ and that process contains numerous opportunities for defeating those preferences.

The empirical evidence about delegations conveys the concrete lesson that, even when legislative gerrymandering is not blatant, ${ }^{490}$ legislative rules and procedures are not neutral phenomena. ${ }^{491}$ Legislative structures are organized to elicit and endorse a wide variety of values and preferences, and voting rules can alter the fora for considering these values and preferences. ${ }^{492}$ Rules structure decisionmaking and limit the consideration of legislative proposals. ${ }^{493}$ Policy outcomes vary with the rules used, ${ }^{494}$ and changes in legislative rules

489. See Pildes \& Anderson, Slinging Arrows, supra note 473, at 2180 (describing legislative structures as forum where value preferences are elicited and endorsed).

490. Professor Guinier has coined the phrase "legislative gerrymanders" to describe the exclusion of representatives elected by black voters from legislative deliberations; it captures the close resemblance to traditional gerrymanders which prevent minority-supported candidates from being elected to office. See Guinier, Triumph of Tokenism, supra note 195, at $1126 \mathrm{n} .242$ (also suggesting term "deliberative gerrymandering"). Before Presley, several commentators argued that legislative gerrymanders were actionable under the Voting Rights Act. Karlan, supra note 196, at 240 (excluding black representatives from school bond proposals); Edward J. Sebold, Note, Applying Section 2 of the Voting Rights Act to Single-Member Offices, 88 MICH. L. REV. 2199, n.255 (1990) (excluding minority city councilmember from deliberations between mayor and city council).

491. See LeWIS A. Froman, JR., THE CONGREssional PROCESS: STRATEGES, RULES AND PROCEDURES 188 (1967) (arguing that "rules and procedures define the conditions under which the 'game' will be played"); DENNIS C. MUELLER, PUBLIC CHOICE 19-67 (1979) (discussing the characteristics of various voting rules).

492. Pildes \& Anderson, Slinging Arrows, supra note 473, at 2180-81 (describing role of United States House of Representatives Rules Committee in framing terms of legislative debate).

493. Studies of this phenomenon include: STEPHEN K. BAILEY, CONGRESS MAKES A LAW: THE STORY BEHIND THE EMPLOYMENT ACT OF 1946 (1950); JOHN A. FEREJOHN, PORK BARREL POLITICS: RIVERS AND HARBORS LEGISLATION, 1947-1968 (1974); W. Mark Crain \& Robert D. Tollison, Legislative Size and Voting Rules, 6 J. LEGAL STUD. 235 (1977); Ronald D. Hedlund, Organizational Attributes of Legislative Institutions: Structure, Rules, Norms, Resources, in HANDBOOK, supra note 20, at 321-95; Ronald D. Hedlund \& Keith E. Hamm, Institutional Development and Legislature Effectiveness: Rules Changes in the Wisconsin Assembly, in COMPARATIVE LEGISLATIVE REFORMS AND INNOVATIONS 173-213 (Abdo Baaklini \& James Heaphy eds., 1977) [hereinafter Hedlund \& Hamm, Institutional Development].

494. Karlan, supra note 196, at 245-48 (describing impact of supermajority rules on black elected officials); Douglas Rae \& Michael Taylor, Decision, Rules and Policy Outcomes, 1 BRIT. J. POL. SCI. 71 (1971) (describing way in which individuals and institutions interact in developing policy); Kenneth A. Shepsle, Institutional Arrangements and Equilibrium in Multidimensional Voting Models, 23 AM. J. POL. SCI. 27 (1979) (describing the interactions of individuals and institutions in voting); James Steiner, The Principles of Majority and Proportionality, 1 COMP. POL. STUD. 63 (1971). Proponents of civic republicanism also point to the value of legislative deliberations and their relationship to fairer legislative outcomes. See, e.g., Cass R. Sunstein, Beyond the Republican Revival, 97 YALE L.J. 1539 (1988); Cass R. Sunstein, Interest Groups in American Public Law, 38 STAN. L. REV. 29 (1985). 
and procedures affect interest groups in different ways. ${ }^{495}$ Thus, legislative rules and procedures should be closely scrutinized to ensure that minority voting power is protected.

\section{B. Who Has the Power?}

In addition to legislative decision rules, other aspects of the legislative process have the potential to affect outcomes. The distribution of power within a political system is closely related to legislative rules and procedures. Indeed, the potential for wholesale transfers of governmental powers within a single entity, or from one level of government to another, is perhaps even more troubling for minority voters than the unchecked opportunities for manipulating legislative processes. In many respects, these kinds of transfers are easier to implement than gerrymanders or rule changes but are equally effective at eviscerating black electoral gains. Again, legislative delegations provide a useful context in which to examine this question.

Delegations highlight the multiplicity of ways in which the legislative process can be structured, as well as the variety of locations in which governmental power can be vested. Power over local matters can reside with local governing bodies, with the state legislature, or with delegations. These bodies are in turn free to delegate their authority to component structures such as committees. None of these choices is any more neutral than the decision about where to draw a legislative districting line, and each potentially has a profound impact on the real voting strength of black voters.

Consider, for example, the new "work group" procedures employed in Georgia for drafting the recent legislative reapportionment plan. Rather than following the previous practice of assigning local delegations the responsibility to develop initial drafts of local reapportionment plans, ${ }^{496}$ the legislature instead entrusted this task to work groups composed of all legislators representing the districts included in nineteen designated work areas. ${ }^{497}$ The work groups were directed to develop new legislative district boundaries for their region conforming to work area boundaries. If the work group members were in

495. Ronald D. Hedlund \& Keith E. Hamm, Conflict and Perceived Group Benefits from Legislative Rules Changes, 1 LEGIS. STUD. Q. 181 (1976); Hedlund \& Hamm, Institutional Development, supra note 493, at 207-08; Ronald D. Hedlund \& Keith E. Hamm, Institutional Innovation and Performance Effectiveness, in LEGISLATIVE REFORM: THE POLICY IMPACT 117-32 (Leroy N. Rieselbach ed., 1978). A contemporary example of the impact of legislative reforms on the legislative process is the 1970's revolt of liberal Democrats in the United States House of Representatives and the decentralization of power that resulted. Bruce I. Oppenheimer, Policy Effects of US. House Reform: Decentralization and the Capacity to Resolve Energy Issues, 5 LEGIS. STUD. Q. 5 (1980) (describing impact of reforms on success of energy legislation).

496. Busbee v. Smith, 549 F. Supp. 494 (D.D.C. 1982), aff d, 459 U.S. 1166 (1983).

497. See ACLU Comment Letter, supra note 307, at 19; House Reapportionment Committee, Work Area Map and Statistics (adopted May 9, 1991) (on file with author). In most instances, work areas were composed of more than one county; in one instance, as many as thirty-one counties were placed under the jurisdiction of a single work group. 
agreement, the proposed area plan was adopted without further review. Where there was some dispute among incumbents, however, the plan was submitted to the house reapportionment committee for a deciding vote. ${ }^{498}$

In its section 5 objection letter, the Department noted that "the state's 'work group' system and rules for the members of the house worked to benefit incumbents and minimize black voting strength. ${ }^{, 499}$ By placing power in the hands of incumbent legislators (most of whom were white), the system encouraged maintenance of the status quo and discouraged the creation of new black districts. ${ }^{500}$ Moreover, the new legislative districts were supposed to lie entirely within the work area lines, which themselves fractured concentrations of black voters. The effect of this arbitrary work area restriction was to reduce the number of black voters who could be included in certain legislative districts, as well as to divide incumbent black legislators among work areas so that they would typically be a smaller percentage of a work group than of a delegation. ${ }^{501}$

The potential for undermining black voting strength within delegations themselves is also enormous. Consider the Dougherty County, Georgia delegation, on which black members recently became a majority. ${ }^{502}$ It would be a simple matter for the legislature to change the rules of the game and vest many of the powers exercised by the delegation in the hands of a different entity-such as the committee with jurisdiction over local legislation in the Georgia House of Representatives. ${ }^{503}$ Presley would impose no voting rights barrier to such a transfer of power, even if no black legislators served on the committee (or indeed, if black legislators were deliberately excluded from committee membership). Presley would not stand in the way unless the transfer took away all of the powers exercised by delegations.

This result is patently absurd. Imagine a legislative "committee" for Dougherty County that exercised the wide variety of powers currently exercised by the delegation - that is, chose the method of election for the county governing body; approved annexations and consolidations; passed local options sales taxes; appointed members to boards and commissions; and so forth. In other words, imagine a body with the powers described in Part I of this Article, but outside

498. ACLU Comment Letter, supra note 307, at 19.

499. First Georgia Objection Letter, supra note 305, at 3.

500. ACLU Comment Letter, supra note 307, at 19. In objecting to the legislative reapportionment that resulted from the work group system, the Department of Justice found that other new rules and procedures "discouraged alternative redistricting plans from being presented and debated." First Georgia Objection Letter, supra note 305 , at 2 . Although the Department did not identify the nature of these rules, it went on to note that "the state often rushed the process in order to manipulate the adoption of plans that minimize minority voting strength overall." Id.

501. ACLU Comment Letter, supra note 307, at 20.

502. See supra notes 307-29 and accompanying text.

503. On one level, this is simply an expansive variant of the Fulton County reapportionment case, in which the legislature overruled the decision of the delegation in one instance. Rather than proceeding on a case-by-case basis, a transfer of power to a committee would completely divest the delegation of jurisdiction over certain matters. 
of the dilution analysis described in Part III. The composition of this body is no less disturbing than that of the Dougherty County delegation, yet Presley would provide no tools for analyzing its impact on black voters.

Looking beyond delegations to other legislative bodies, we discover that Presley leaves unexamined two other structures in which significant legislative power is lodged-legislative committees ${ }^{504}$ and legislative leadership positions. Legislative leaders introduce more legislation than their colleagues, enjoy more success in passing legislation, ${ }^{505}$ and are perceived by their colleagues as wielding more influence in the legislative process. ${ }^{506}$ Although the significance of legislative committees in the decisionmaking process varies from state to state ${ }^{507}$ they exercise a great deal of influence in most jurisdictions. Yet while the individuals occupying these positions can exercise greater influence over the process than their numbers would seem to justify, neither the composition nor the procedures of legislative committees are cognizable under the Voting Rights Act. ${ }^{508}$

Although my research indicates that the access of representatives elected by black voters to committees has not been challenged under the Voting Rights Act, there are several documented instances in which black representatives have been excluded. In Louisiana, the decisionmaking processes for the post- 1980 congressional redistricting plan effectively excluded the voices of black legislators. While black legislators did serve on the Louisiana House and Senate Joint Congressional Reapportionment Committee, no black legislators were appointed to the ad hoc subcommittees charged with promulgating rules for the design of the new plan. ${ }^{509}$ When Governor Treen threatened to veto any plan that created a majority-black district, white legislators convened a private meeting in the sub-basement of the state capitol, to which black legislators were not invited. ${ }^{510}$ The white legislators who attended the meeting drafted a compro-

504. In Presley, the Court announced that "[i]nnumerable state and local enactments having nothing to do with voting affect the power of elected officials" and gave as an illustrative example "when a state or local body alters its internal operating procedures, for example by modifying its subcommittee assignment system ...."112 S. Ct. at 829.

505. DONALD R. MATTHEWS, U.S. SENATORS AND THEIR WORLD 174-75 (1960) (majority party leaders most effective); Stephen E. Frantzich, Who Makes Our Laws?: The Legislative Effectiveness of Members of the U.S. Congress, 4 LEGIS. STUD. Q. 409, 427 (1979); Hamm et al., Ethnic \& Partisan Minorities, supra note 372 , at 186 (leadership and seniority most accurately predict legislative activity and success in South Carolina and Texas legislatures).

506. Charles G. BEll \& CHARLES M. PRICE, THE FIRST TERM: A STUDY OF LEgISLATIVE SOCIALIZATION 160 (1975); James J. Best, Influence in the Washington House of Representatives, 15 MDWEST J. POL. ScI. 547, 554 (1971); Katherine Meyer, Legislative Influence: Toward Theory Development through Causal Analysis, 5 LEGIS. STUD. Q. 563, 580 (1980).

507. JEWELL \& PATTERSON, supra note 135, at 165 (citing 1982 study assigning committee centrality scores based on significance of committee to legislative decisionmaking).

508. One of the most powerful critiques of the democratic process is the extent to which the outcome of the legislative process is manipulated by party leaders and other elites. See Pildes \& Anderson, supra note 473 , at $2137-38,2196$.

509. Major v. Treen, 574 F. Supp. 325, 330 (E.D. La. 1983).

510. Id. at 334. 
mise reapportionment plan which was formally reviewed by an all-white conference committee. Once adopted, it became known as the "Donald Duck" plan for its bizarre configuration, and was later invalidated in a section 2 lawsuit. 511

The reapportionment plan for Georgia's congressional districts followed a similar pattern. After the senate and house adopted dramatically divergent districting plans, a conference committee was appointed to resolve the differences. ${ }^{512}$ No black legislators were appointed to the conference committee, which a court later characterized as the "ultimate decision-makers in the congressional reapportionment process." ${ }^{\text {"513 }}$ The Georgia General Assembly ultimately adopted a plan splitting the politically cohesive community of black voters in the Atlanta metropolitan area between two congressional districts; this plan was later rejected by a federal court. ${ }^{514}$

For elections to be more than merely symbolic, the legislative process must provide access to the entire spectrum of interests reflected in the election of diverse representatives. If the legislative process is flawed, then the election of representatives is of limited value. A comprehensive examination of this process is needed to ensure that the voting power of minority voters is equal to that of white voters.

\section{After Presley}

The question, then, is how to conceptualize voting so that the right to vote is part of an extended political process. Before Presley, legal scholars had just begun to assert that the election of candidates was only a partial means of achieving the goal of full participation in the political process. These scholars argued that post-election assertions of influence are a crucial aspect of political participation and that minority voters must have equal access to that process

511. Id. at 355. For a comprehensive description of the various political and racial machinations of the case, see Guinier, supra note 369, at 408-11 (implicating Assistant Attorney General William Bradford Reynolds in "race-conscious effort to assure the re-election of a white Republican incumbent"); Pamela S. Karlan and Peyton McCrary, Without Fear and Without Research: Abigail Thernstrom on the Voting Rights Act, 4 J.L. \& POL., 751, 770-72 (1988).

512. Busbee v. Smith, 549 F. Supp. 494,509 (D.D.C. 1982), aff d, 459 U.S. 1166 (1983).

513. Id. at 510. The court found that the Speaker of the House "refused to appoint black persons to the conference committee solely because they might support a plan which would allow black voters, in one district, an opportunity to elect a candidate of their choice." Id. The court refused to preclear the plan under section 5, rejecting as a "cover-up" the "contradictions, illogical justifications and feigned ignorance" offered by the state at trial. Id. at 515 . The court placed much of the blame on two legislative leaders in the Georgia General Assembly: Speaker of the House Thomas Murphy, and Representative Joe Mack Wilson, Chairman of the House Permanent Standing Committee on Legislative and Congressional Reapportionment. In a rare demonstration of judicial candor, the court branded Representative Wilson a "racist" $i d$. at 500 , and noted Speaker Murphy's comment following his speech to a virtually all-white audience, when he joked "[w]ouIdn't you love to have a district like that [audience]?" Id. at 510.

514. Busbee, 549 F. Supp. at 499. 
for the value of electing representatives to be fully realized. ${ }^{515}$ The Presley Court rejected a vision of statutory voting rights that would embrace decisions about how power is distributed in the political system. It expressly held section 5 inapplicable to the post-election phase, and although the Court did not consider section 2 , the case for section 2 coverage is arguably weaker..$^{516}$

Currently, the Equal Protection Clause of the Fourteenth Amendment affords the only basis for challenging racial discrimination in the political process. $^{517}$ Plaintiffs alleging a constitutional violation are required to prove discriminatory purpose. ${ }^{518}$ Because proof of intent is difficult and time-consuming, ${ }^{519}$ only an amendment of the Voting Rights Act can fully protect voting rights in the post-election phase.

An amendment to sections 2 and 5 of the Voting Rights Act would permit courts to examine not only the purpose, but also the effect on minority voters of various choices allocating decisionmaking authority at various levels of government. For several reasons, section 5 holds the most promise as a barrier to discriminatory applications of decisionmaking authority and legislative rules and procedures. Section 2 could serve as an avenue of relief in non-section 5 jurisdictions, or as an alternative to section 5 in jurisdictions where the rules

515. See, e.g., Abrams, supra note 195, at 488 (basic flaw of "preference aggregation" model of vote dilution, which focuses on electoral outcomes, is that other events "help translate election results into substantive policy"); Guinier, supra note 369 , at 427 ("[A] meaningful right to vote contemplates minority participation in post-election legislative policymaking as well as pre-election coalition building and deliberation"); Guinier, supra note 29, at 1416 (new conceptual approach needed to "ensure meaningful minority interest representation and participation at both the electoral and legislative stages of the political process"); Guinier, Triumph of Tokenism, supra note 195, at 1126 (suggesting that "prejudice may simply transfer the 'gerrymandering' problem from the electorate to the legislature"); Karlan, supra note 196, at 180 (urging courts to "look beyond the voting booth to the council chamber and the 'voting' (decisionmaking) that occurs there."); Karlan, supra note 2, at 30 (ability to elect is a "subset" of right to participate in broader political process). See also Levinson, supra note 476, at 272 ("fair" electoral systems do not guarantee "faimess" within the legislature); Peter Schuck, The Thickest Thicket: Partisan Gerrymandering and Judicial Regulation of Politics, 87 COLUM. L. REV. 1325, 1363 (1987) (election systems that afford minority groups ability to elect candidates may nonetheless "waste" minority voting strength where representatives are excluded from legislative coalitions and alliances). Professor Guinier is the most vigorous and articulate advocate of this view.

516. See supra note 243 and accompanying text. Before Presley, some commentators suggested that section 2 should be read to reach all stages of the political process. See Karlan, supra note 196, at 198 \& n.98 (section 2 addresses not only electoral mechanisms but "any practice denying equal access") (citing H.R. Rep. No. 227, 97th Cong., 1st Sess. 31 (1982)); Sebold, supra note 490, at 2240 (section 2 enacted to address situations where "racial politics dominates the political process"). However, no court has considered its application to the post-election stage. See supra note 29 and accompanying text for a discussion of the relationship between section 2 and section 5 .

517. The Court in Presley suggested that racial discrimination in the political process could be attacked under a remedial scheme other than the Voting Rights Act, 112 S. Ct. at 832, and the Fourteenth Amendment affords a likely vehicle for such an attack. The Fourteenth Amendment reaches all forms of racial discrimination whereas the Fifteenth Amendment extends only to the right to vote. See Searcy v. Williams, 656 F.2d 1003, 1010 (5th Cir. 1981), aff d sub nom. Hightower v. Searcy, 455 U.S. 984 (1982). The Court would likely find any discrimination in the post-election phase unrelated to voting and thus outside the reach of the Fifteenth Amendment.

518. Mobile v. Bolden, 446 U.S. 55, 66 (1980); Washington v. Davis, 426 U.S. 229 (1976) (proof of discriminatory purpose required under equal protection elements of Fifth and Fourteenth Amendments).

519. Parker, supra note 228; Soifer, supra note 228; Pamela S. Karlan, Note, Discriminatory Purpose and Mens Rea: The Tortured Argument of Invidious Intent, 93 Y ALE L.J. 111 (1983). 
had not changed but the status quo nonetheless discriminated against black voters.

Under an amended section 5, the burden of demonstrating the absence of both discriminatory purpose and effect for any change to the status quo would shift to the submitting jurisdiction. Where courts might otherwise be reluctant to find that legislative structures discriminated against minority voters, this burden-shifting device would increase the likelihood that discriminatory changes would be invalidated. In addition, the section 5 "effects" test would prohibit any change that diminishes the voting power of black voters. Under this test, the court could compare the relative influence of minority voters under two existing procedures, and would not have to answer the more difficult question under section 2 of how much influence minority voters should have. ${ }^{520}$

Admittedly, measuring the effects of legislative decisionmaking rules on minority voters is a difficult task. Any measure of effects necessarily involves the question of how much influence minority voters should have in the legislative process, as well as difficult comparisons regarding the impact of different rules in various legislative contexts. Discrimination is a complex and difficult phenomenon requiring a definition of equality and some consensus about permissible deviations from equality. It is unlikely that the standard for assessing discrimination will lend itself to the kind of bright line rule for electoral systems dilution that the Court sought in Gingles, but the absence of a mechanical test does not indicate that courts should avoid a broader examination of the political process. ${ }^{521}$

As a practical matter, we should recognize that courts may be tempted to defer to the choices that governing bodies have made in structuring their internal processes. These decisions might be viewed as the product of a kind of expertise that courts lack, or seen as political choices that should be left to political bodies. Unless courts are convinced that governing bodies have set out to curtail the political influence of minority voters, they may take a hands-off approach.

Nonetheless, even this approach would be preferable to Presley's wholesale abandonment of the inquiry. Although intent is difficult to prove at any stage of the political process, proving the purpose behind a particular rule should be no more difficult than proving the purpose of any action. In examining intent,

520. The effects test for both sections is a comparative one that measures the existing election procedure against a benchmark. The key difference between the two tests is that the section 5 effects tests looks at whether the change makes black voters worse off than they were before, while the section 2 test measures the status quo against other alternatives. While conceptually a section 2 effects test could be applied to legislative procedures, the potentially open-ended nature of the dilution inquiry under section 2 , coupled with the lack of empirical evidence concerning the impact of various decisionmaking procedures on minority voters, would make this assessment difficult. In the familiar context of vote dilution, the measure of discriminatory effect under section 2 haunted voting rights litigation for years until Gingles furnished some clarification, and challenges to legislative structures would face similar problems.

521. In a provocative article, Professor Guinier offers some suggestions for measuring discrimination in the post-election phase. See Guinier, supra note 29, at 1493-1508. 
courts must necessarily strive to understand complex legislative processes, including the reasons for the decision and the availability of other alternatives. ${ }^{522}$ Legislative structures, like other mechanisms, advantage certain groups and disadvantage others and it should be the business of the law to determine when this impact amounts to discrimination.

Perhaps the most persuasive criticism of expanding vote dilution theory for the purpose of remedying inequalities in the distribution of political power is that this theory is not a panacea for racial justice. Vote dilution doctrine, however broadly conceived, cannot even reach many of the pressure points within government, let alone those that are enmeshed in our political and social culture. ${ }^{523}$ Money often dictates the outcome of elections at all levels of government. ${ }^{524}$ We are governed by an administration that seems intent on inflaming racial passions ${ }^{525}$ and that has little commitment to remedying inequality. We live in a country where wealth and power are distributed unevenly, and where the white majority resists the efforts of minorities to claim these resources. ${ }^{526}$ Many people have become disenchanted with traditional avenues of political reform, and voter participation is at an all-time $10{ }^{527}$ Fine tuning rules of legislative decisionmaking cannot overcome these obstacles.

The solution to this dilemma is obviously beyond the scope of this Article. ${ }^{528}$ The critique, however, applies equally to the other aspects of the political process that have been vigorously attacked by voting rights advocates. A realistic view of political participation must take into account all of its stages.

522. See Arlington Heights v. Metropolitan Hous. Dev. Corp., 429 U.S. 252, 264-68 (1977).

523. For instance, black electoral success has been thwarted by a number of outside sources, including: other public officials, see EDWARD GREER, BIG STEEL: BLACK POLITICS AND CORPORATE POWER IN GARY, INDIANA 111-160 (1979); reluctant bureaucracies, see RUFUS P. BROWNING, ET AL., PROTEST IS NOT ENOUGH: THE STRUGGLE OF BLACKS AND HISPANICS FOR EQUALITY IN URBAN POLITICS 53-61 (1984); and elites outside of the political system, see GREER, supra at 119-32.

524. For studies of the impact of money on elections, see Ragsdale, supra note 20, at 62 (citing GARY JACOBSEN, THE POLIMCS OF CONGRESSIONAL ELECTIONS (1983)); W.P. Welch, The Effectiveness of Expenditures in State Legislative Races, 4 AM. POL. Q. 333 (1976).

525. Elizabeth Drew, Letter from Washington, THE NEW YORKER, June 17, 1991, at 102, 112 (President Bush's "performance has been nothing less than shameful" in his recent campaign against quotas); Notes and Comment, THE NEw YORKER, July 1, 1991, at 22 (President Bush is "willing to play the anti-black race card" in 1988 campaign and civil rights agenda).

526. We have not come so far from the time when Walt Whitman intoned, "is not America for the Whites? And is it not better so?" Notes and Comment, THE NEW YORKER, July 1, 1991 (quoting 1858 article in BROOKLYN DAILY TMES).

527. See Alan Ehrenhalt, The Rise of a Politician Class: Why Voters Don't Matter, WASH. Post, July 21, 1991, at C3. The classic work of Frances Fox Piven and Richard Cloward explains voter "apathy." FRANCES PIVEN \& RICHARD CLOWARD, WHY AMERICANS DON'T VOTE (1988). See also E.J. DIONNE, JR., WHY AMERICANS HATE POLITICS (1991). For a discussion of citizens' growing disenchantment with our political system, see ALAN EHRENHALT, THE UNITED STATES OF AMBITON: POLITICIANS, POWER AND THE PURSUIT OF OFFICE (1991).

528. The critique applies more broadly to the limits of law in achieving social justice. See Judy ScalesTrent, A Judge Shapes and Manages Institutional Reform: School Desegregation in Buffalo, 17 N.Y.U. REV. L. \& SOC. CHANGE 119, 168 (1989-90) (describing “complicated fabric' of change" including many govemment and private sector players). 
Since elections alone cannot provide access to governance, the post-election phase should be scrutinized.

At this point in time, little is known about the extent of discrimination in the post-election phase. My hope is that opening it up to scrutiny will provide a better understanding of the legislative process and the tools that make the process more responsive to a broad spectrum of interests. Absent this outcome, the image is one of layer upon layer of governmental structures, each capable of depriving minority voters of hard-earned gains.

Delegations are a case in point. While the fairness of elections to formally constituted governing bodies captured the attention of voting rights advocates, delegations operated in virtual obscurity. As long as legislative reapportionments resulted in fair election districts for the state legislature, the impact of legislative reapportionments on delegation membership was never examined. As a result, our understanding of legislative reapportionments and annexations was cramped and narrow. Opening up the world of delegations reveals a new dimension of these phenomena. Experience teaches that digging below the surface of elections will enrich our understanding of the right to vote.

\section{CONCLUSION}

Voting rights advocates and courts have too often overlooked questions of political power. As the Reverend Martin Luther King once said, "The vote is not the ballgame, but it gets you inside the ballpark." ${ }^{\text {229 }}$ Once inside the ballpark of politics, a group's right to vote may be abridged at many steps along the way. Minority voting strength can be eviscerated not only by formal restrictions on political participation or by the way candidates are elected, but also by the manner in which political power is apportioned.

Local legislative delegations hold a great deal of political power in the South. From supervising greyhound racing to selecting local school boards, local delegations make a host of crucial decisions that affect their constituents' daily lives. Delegations, along with local legislatures, rule and govern the cities and counties under their jurisdiction. Yet racial discrimination has infused the politics of delegations since their inception. For black voters to achieve fuller political participation, the method of selecting delegations should be subject to challenge under the Voting Rights Act. By the same token, the Act should be amended to protect minority voters during the post-election phase of the political process and to ensure that their ability to speak through their representatives is not diminished.

529. Chestnut \& Cass, supra note 106, at 235. 